Universidade de São Paulo

Instituto de Física

Instituto de Química

Instituto de Biociências

Faculdade de Educação

\title{
Grupos de Monitoria Discente de Física: a trajetória de um projeto inovador
}

\author{
Luciana Faustino Guimarães
}

Orientador: Prof. Dr. Alberto Villani

Dissertação de mestrado apresentada ao Instituto de Física, ao Instituto de Química, ao Instituto de Biociências e a Faculdade de Educação da Universidade de São Paulo, para a obtenção do título de Mestre em Ensino de Ciências. 


\author{
Universidade de São Paulo \\ Instituto de Física \\ Instituto de Química \\ Instituto de Biociências \\ Faculdade de Educação
}

\title{
Grupos de Monitoria Discente de Física: a trajetória de um projeto inovador
}

\author{
Luciana Faustino Guimarães
}

Banca Examinadora

Prof. Dr. Alberto Villani (IFUSP)

Prof. Dr. Cristiano Rodrigues de Mattos (IFUSP)

Prof. Dr. Juarez Melgaço Valadares (Centro Universitário de Sete Lagoas) 
FICHA CATALOGRÁFICA

Preparada pelo Serviço de Biblioteca e Informação do Instituto de Física da Universidade de São Paulo

Guimarães, Luciana Faustino

Grupos de monitoria discente de física: a trajetória de um projeto inovador - São Paulo - 2009.

Dissertação (Mestrado) - Universidade de São Paulo. Instituto de Física - Depto. de Física Aplicada

Orientador: Prof. Dr. Alberto Villani

Área de Concentração: Ensino de Ciências

Unitermos: 1. Ensino; 2. Física; 3. Ensino e Aprendizagem - processo grupal; 4. Ensino e Aprendizagem - monitoria Discente; 5. Ensino Médio 
Aos meus pais Pedro e Zizi, pelo amore apoio incondicionais... 


\section{Agradecimentos}

Aos meus pais e meu irmão Vinicius, pelo apoio em minhas decisões, suporte em todos os momentos, pela valiosa educação, por sua presença constante (mesmo que fisicamente distantes) e amor incondicional.

Ao Villani, pela orientação, apoio e compreensão em meus momentos de crise com o trabalho. Por escutar pacientemente as reclamações, as dúvidas e compartilhar as conquistas, sempre indicando caminhos e mais reflexões.

Ao Maicol, que transformou minha vida já na reta final deste trabalho. Obrigado pela serenidade que me trouxe, pela compreensão, pela paciência, por estar presente e entender meus momentos de ausência. Obrigado pelo amor, por me completar.

Aos amigos Adriane, Clovis e Marcília, pelo apoio, pelas conversas, pelos passeios, pelas risadas e companhia nos primeiros meses de São Paulo, quando a saudade de Curitiba e dos que lá estavam e a estranheza na nova cidade ainda assustavam.

Aos grandes amigos do corredor de ensino Esdras, Roseline, Breno, Giselle, Renatinha, Cris, Lucia Helena, Max, André, Francisco, Ricardo, Fábio e Anne pelos agradáveis e produtivos (e também pelos improdutivos!) momentos que passamos juntos. Cada um contribuiu enormemente para a realização deste trabalho, não apenas através das discussões acadêmicas, mas também com a amizade e a ajuda em todos os momentos. À Aninha que foi fundamental em meus primeiros passos como professora de Física. À Thais, pelas longas conversas nos momentos mais difíceis, pelo apoio mesmo quando não entendia meus pensamentos, pelo companheirismo em todas as situações, por sua risada gostosa que faz com que outros sorrisos se abram, por seu imenso coração!

À Jackelini, pela longa amizade iniciada nos tempos da graduação e que espero seja eterna. Pelos infinitos conselhos, por compartilhar os segredos, os momentos de alegria e de tristeza, por sua sensibilidade. Infinitos "obrigados". 
Ao Glauco, amigo tão especial com quem se pode sempre contar, certamente uma das pessoas que mais sabem ouvir. Obrigado pela generosidade, pela inspiração que me proporciona por sua convicção nos caminhos que vem trilhando, pelas longas discussões que tivemos, por ler meus textos (mesmo que na última hora) e entupi-los com milhões de comentários que me deixavam desesperada, por suas sugestões quando resolvia "brincar de orientador por um dia". Obrigado pela amizade.

Aos amigos e companheiros do grupo de pesquisa Dora, Verônica, Beth, Valéria, Joana, Juarez, Helô, Maísa, Luciano, Diógenes, Ana, Marlene, Marco Aurélio e Isabel pelas infindáveis discussões, palpites, questionamentos e elogios.

À Ivanilda, grande responsável pela minha decisão de enfrentar essa empreitada, pelo incentivo, pelas conversas, pelo acolhimento nas primeiras vindas à São Paulo, pela torcida e por ainda se emocionar com os resultados de seus "velhos" alunos da UFPR.

Ao Cristiano, pelas grandes conversas vitais que tivemos, pelas discussões acadêmicas e pelas discussões filosóficas sobre a vida, por pacientemente escutar minhas dúvidas e angústias em cafés, em viagens, no corredor... por me incentivar e insistir que sempre há uma saída. Obrigado pelas discussões que certamente expandiram horizontes.

Ao Eraldo, por abrir as portas de seu projeto para minha investigação. Pelas conversas que tanto contribuíram para minhas reflexões sobre o ensino de Física. Aos monitores de 2005 e 2006, que trabalharam arduamente na monitoria e ainda estiveram dispostos às gravações e entrevistas.

À banca examinadora, tanto de qualificação como de defesa, pela leitura, pelas críticas e pelas discussões que só enriqueceram o trabalho.

Aos funcionários Ailton, Camila, Leo, Ellen, Thomas, Fran e Lia pelo atendimento sempre eficiente e atencioso.

À CAPES pelo apoio financeiro. 


\section{RESUMO}

Numa escola particular da cidade de São Paulo, em 2002, o professor de Física propôs um novo projeto: desenvolver uma monitoria com seus alunos do $1^{\circ}$ ano do Ensino Médio. Alguns alunos foram selecionados e convidados a atuarem como monitores de seus colegas de turma na disciplina de Física. Sua função era estar sempre à disposição dos colegas para ajudá-los, coordenar plantões de dúvidas em horários previamente definidos e participar de outras atividades ligadas à monitoria propostas pelo professor ao longo do ano. O grupo, formado pelos monitores e o professor, se encontrava uma vez por semana para discutir assuntos relacionados à monitoria. Nos anos seguintes a experiência foi repetida com novos grupos de alunos, obtendo bons resultados, sendo que os grupos se tornavam criativos e capazes de solucionar problemas. Depois de três anos de sucesso, passamos a acompanhar os grupos nos anos de 2005 e 2006, com turmas do $3^{\circ}$ ano do Ensino Médio. Diferente dos anos anteriores, os grupos estavam pouco engajados na tarefa de ajudar os colegas e não enfrentavam os problemas com criatividade. Assim, nos propusemos a investigar o processo de ascensão e declínio do projeto de monitoria identificando as dinâmicas grupais estabelecidas em cada uma das suas cinco edições. Para tanto, utilizamos como referencial teórico a teoria de grupos operativos de Enrique Pichon-Rivière, que leva em conta aspectos subjetivos que permeiam o trabalho coletivo. Nossos dados foram compostos pelo relato do professor referente aos anos que não acompanhamos, e gravações em vídeo dos encontros, entrevistas com os monitores e com o professor e notas de campo dos anos em que estivemos presente nas reuniões de monitoria. Constatamos que fatores como a mudança de contexto do projeto (do primeiro para o terceiro ano do ensino médio), as relações afetivas estabelecidas entre os membros do grupo e o envolvimento da instituição são fatores importantes para a implantação de um projeto inovador no ambiente escolar. 


\begin{abstract}
In 2002, a Physics teacher from a private school in the city of São Paulo proposed a new project: students from the first year of High School acting as tutors of their classmates. Some students were selected and invited to take part in this project by assisting their classmates from the Physics class as if they were their tutors. They were supposed to be always available to help their classmates, coordinate "doubt sessions" in previously defined times and join other activities suggested by the teacher throughout the year. The group, formed by the tutors and the teacher, met once a week to discuss issues related to the project. In the following years, the experience was repeated with new groups of students and it was possible to notice good results, since they became more creative and capable of solving problems. After three successful years, we started observing the groups from 2005 and 2006, with students from the third year of High School. Unlike the previous years, the groups were little engaged in the task of helping the classmates and they didn't face the problems with creativity. That way, we proposed to investigate the process of rising and decline of the project identifying the group activities established in each one of the five editions. For that, we used as a reference, the operative groups' theory of Enrique Pichon-Rivière, which considers the subjective aspects that concern the collective work. Our data came from the report of the teacher about the years we didn't observe, video records of the meetings, interviews with the tutors and with the teacher and notes from the years that we were present during the meetings of the project. We noticed that factors like the change of context of the project (from the first to the third year of High School), the affective relationships established among the members of the group and the engagement of the institutions are important to the establishment of an innovative project in the school environment.
\end{abstract}




\section{SUMÁRIO}

Capítulo 1 -Grupos de Aprendizagem e Monitoria Discente

Apresentação

Justificativa e Trabalhos Relacionados __ 13

O que é grupo? _ 16

Monitoria, grupos e psicanálise

A Seqüência — 21

Capítulo 2 - A Pesquisa _ 23

Objetivos__ 23

Metodologia _ 24

A Escolha do Caso _ 25

Coleta de Dados 26

Análise de dados — 28

Capítulo 3 - Grupos Operativos___ 30

Grupos centrados na tarefa__ 33

Idéias-base _ـ 33

A tarefa

O vínculo — 34

A dinâmica grupal __ 35

Ansiedades básicas__ 35

Papéis assumidos e adjudicados__ 36

Momentos_ 38

Vetores de avaliação da dinâmica grupal __ 40

Concluindo _ 41

Capítulo 4 - Monitoria Discente de Física: uma experiência de sucesso _ 43

A Gênese _ 43

2002 - Um Aprendizado para o Modelo de Monitoria___ 46

2003 - A Segunda Edição da Monitoria___ 48

2004 - O Coroamento da Monitoria Inter-séries __ 57

Portanto... 58

Capítulo 5 - Um Novo Ano. Uma Nova Série. Uma Nova Monitoria? __ 62

O Contexto _ 62

A Formação do Grupo _ 63

Os Eventos _ 64

$1^{\circ}$ semestre 65

$2^{\circ}$ semestre

Algumas reflexões sobre a formação deste grupo ___ 84

Interpretação do desenvolver grupal ___ 85

Relações Estabelecidas __ 87

A Nova Tarefa __ 96 
Capítulo 6 - O Último Ano 100

Promessas de mudança 100

A formação do grupo e o início da pesquisa 101

Os eventos 102

Iago: o porta-voz 110

Estagnação do grupo e fim do projeto 116

Considerações Finais 121

Conclusões sobre a trajetória do projeto 121

Considerações sobre o projeto 126

Mais algumas considerações 129

Referências Bibliográficas 132 


\section{Capítulo 1}

\section{Grupos De APREndizagem E Monitoria Discente}

\section{APRESENTAÇÃO}

Inicio este trabalho com um breve relato pessoal, que tem por objetivo explicitar algumas motivações que me levaram ao Ensino de Ciências e ao tema desta dissertação.

No Ensino Médio meu interesse pela Física foi fortemente despertado. As aulas de ciências do ensino fundamental já eram as minhas preferidas e minha habilidade com a área de exatas ficou evidente desde cedo, mas a experiência que tive a oportunidade de vivenciar no colegial foi a que realmente me instigou e ajudou na minha decisão profissional.

Ao terminar a oitava série do Ensino Fundamental fui estudar no CEFET-PR (em Curitiba, onde eu morava com minha família), após um exame de ingresso muito concorrido. Era 1998, e os cursos técnicos de nível médio não poderiam mais ser oferecidos a partir daquele ano, por isso o CEFET abriu vagas apenas para o ensino médio regular (que nunca havia existido antes, pois até então apenas eram oferecidos cursos técnicos). Felizmente, a vontade dos professores que se envolveram em montar a grade curricular do ensino médio era a de oferecer um curso inovador e de qualidade.

Nossa grade curricular era bastante diferente da maioria das escolas. Nós tínhamos disciplinas como orientação educacional, economia e administração, princípios tecnológicos, além das disciplinas "normais". Tudo isso propiciou uma experiência única, pois fiz parte da turma piloto, para a qual várias inovações haviam sido propostas e não se sabia se funcionariam ou não. Chegamos até mesmo a nos apelidar de "cobaias" do Ensino Médio.

Os professores haviam optado por dar aulas para esse novo curso e estavam muito dispostos a uma experiência nova e de sucesso. Uma de minhas lembranças mais fortes é com relação aos interessantes trabalhos que fazíamos para as diversas disciplinas. Os trabalhos em grupo eram muito valorizados e os professores nos desafiavam constantemente.

Hoje, quando penso os caminhos que trilhei até chegar à pós-graduação, tenho certeza de que os momentos que vivi lá foram bastante significativos para as escolhas que fiz em seguida. Certamente meu professor de Física me conquistou com seu brilho no olhar quando falava de Física, com sua maneira de nos mostrar as explicações para 
os fenômenos que vivenciávamos no nosso dia-a-dia e com sua disposição para responder às perguntas que eu fazia quando lia alguma matéria na revista Superinteressante (uma de minhas leituras preferidas na época).

Infelizmente, o curso de Ensino Médio regular no CEFET-PR não durou muito tempo. Embora tenha perdido o contato com os professores daquela época, fiquei sabendo que logo depois de minha saída daquela instituição, a última turma de Ensino Médio foi selecionada. Os cursos técnicos voltaram e poucos alunos, como eu, tiveram a oportunidade de vivenciar aquela experiência de novidades, empenho e luta para implantar uma inovação curricular.

Em 2001, ingressei na graduação com a certeza de que eu queria ser pesquisadora em Física. A docência nem sequer me passava pela cabeça, mas mesmo assim decidi cursar a licenciatura e o bacharelado concomitantemente ${ }^{1}$. No segundo ano da graduação, recebi um convite da coordenadora da escola de idiomas na qual eu fazia curso de inglês para fazer um "teacher training course" e ministrar aulas de inglês na escola, devido ao bom desempenho que apresentava. Aceitei essa oportunidade pensando que seria uma boa forma de ganhar meu próprio dinheiro enquanto cursava a faculdade. Mas nem imaginava que a experiência de ser professora me cativaria tanto.

No último ano da faculdade, quando comecei a fazer as disciplinas de estágio de Física, não tive mais dúvida: queria ser professora de Física! Terminei o bacharelado juntamente com a licenciatura e resolvi tentar a seleção de mestrado em ensino de Física da USP.

Ao receber a notícia de que estava aprovada, era preciso decidir o que iria estudar, afinal ainda não tinha um projeto. Após algumas semanas de reflexão, de muita leitura de trabalhos publicados em revistas de ensino de ciências, e também de relembrar o que tinha vivido quando era aluna no Ensino Médio, decidi que gostaria de trabalhar com grupos. Vivi muitas experiência instigantes (de sucesso e de fracasso) realizando os trabalhos coletivos dentro do CEFET-PR e, ao ler alguns artigos que discutiam questões a esse respeito, vislumbrei um acoplamento entre aquelas idéias teóricas de que tomava conhecimento naquele momento e situações que eu mesma já havia vivenciado como aluna. Muito me intrigava a dinâmica que se estabelecia entre os alunos ao desenvolver um trabalho coletivamente e também o modo como o professor a influenciava. Assim, procurei o professor Alberto Villani, em busca de orientação para

\footnotetext{
${ }^{1}$ Ingressei na UFPR em 2001 no curso de Licenciatura e Bacharelado em Física. Nesta época era possível cursar as duas modalidades ao mesmo tempo ou então escolher uma delas.
} 
um trabalho nessa linha. Não tenho dúvidas de que as experiências que tive como aluna, trabalhando em grupos, foram decisivas para minha escolha.

E quanto à psicanálise? Essa perspectiva fui aprendendo após entrar para o grupo de pesquisa Psicanálise e Educação e começar a trabalhar sob a orientação do professor Villani. O envolvimento com esse referencial aconteceu também por minha gradativa percepção de que através desse recorte eu poderia investigar algumas questões de ordem subjetiva que me inquietavam.

Quando as atividades do mestrado iniciaram, em março de 2005, estava acertado que eu pesquisaria grupos de alunos, e que utilizaria o viés da psicanálise para tentar responder às minhas perguntas. Durante algumas conversas com o orientador, ele comentou que conhecia um projeto de monitoria discente que havia sido implantado por um professor de Física do ensino médio na escola em que trabalhava. Ele conhecia a experiência através do relato do professor e sabia que o projeto era trabalhado através de reuniões semanais do grupo de monitores e o professor.

Logo pensamos que seria interessante acompanhar uma nova edição do projeto (que já vinha acontecendo há três anos) e pesquisar a dinâmica do novo grupo de monitores que se formaria. Para nossa surpresa, os eventos não se desenrolaram tão positivamente quanto havíamos imaginado e com isso formulamos novas questões a respeito daquela experiência. $\mathrm{O}$ que observamos foi um projeto de monitoria, que vinha em um processo de ascensão e sucesso dentro da instituição, entrar em declínio. Diante disso, resolvemos ampliar nosso olhar para a monitoria e buscamos respostas para perguntas relacionadas à implantação de projetos inovadores, mas, sem esquecer nossa motivação inicial sobre os grupos, vimos forte relação entre a dinâmica grupal estabelecida e o rumo do projeto na instituição.

Interessante, depois de revisitar experiências do passado, observar que a monitoria e a inovação curricular proposta na instituição em que cursei o ensino médio, embora fossem projetos de natureza diferentes e que envolviam atores institucionais diferentes, eram inovadores e tiveram trajetórias semelhantes: nascimento, ascensão, sucesso, declínio e morte em poucos anos.

\section{JUSTIFICATIVA E TRABALHOS RELACIONADOS}

Nos últimos tempos, a idéia de que se deve modificar o ensino tradicional que vem sendo praticado parece estar se tornando consenso, pois quer-se oferecer ao aluno 
maior possibilidade de motivação, de mais responsabilidade e de mais criatividade. Com isso, muitas propostas vêm sendo feitas e colocadas em prática, pensando não apenas no resultado final da aprendizagem, mas também no processo percorrido pelos alunos: projetos interdisciplinares, promoção de debates e discussões em sala de aula, ênfase nos problemas do cotidiano do aluno, entre outras. Novas metodologias surgem na tentativa de preparar os alunos para as demandas sócio-político-econômicas da nossa atual sociedade.

Os Parâmetros Curriculares Nacionais (1997), conhecidos como PCNs, são elaborados dentro dessa perspectiva de discutir as condições de ensino e os desafios para sua modificação. Idéias e atitudes educacionais já tão arraigadas, que se perpetuam em um processo transgeracional em que os novos professores atuam segundo os modelos com os quais aprenderam quando eram estudantes, não são nada fáceis de modificar. A própria instituição escola vem se eximindo de sua responsabilidade, se firmando como apenas o cenário no qual ocorre o processo de ensino. Para sairmos desse modelo engessado é necessário que haja mudanças na própria escola, que ela passe a desenvolver atitudes e valores, através de atividades dos educandos como discussões, leituras, observações, experimentações e projetos, e não apenas desenvolver competências como o domínio de conceitos e a capacidade de utilizar fórmulas. É necessário um movimento de mudança de postura em sala de aula.

Os PCNs (1997) enfatizam a necessidade de se adotar métodos de aprendizado ativo e interativo:

[...] Os alunos alcançam o aprendizado em um processo complexo, de elaboração pessoal, para o qual o professor e a escola contribuem permitindo ao aluno se comunicar, situar-se em seu grupo, debater sua compreensão, aprender a respeitar e a fazer-se respeitar; dando ao aluno oportunidade de construir modelos explicativos, linhas de argumentação e instrumentos de verificação de contradições; criando situações em que o aluno é instigado ou desafiado a participar e questionar; valorizando as atividades coletivas que propiciem a discussão e a elaboração conjunta de idéias e de práticas; desenvolvendo atividades lúdicas, nas quais o aluno deve se sentir desafiado pelo jogo do conhecimento e não somente pelos outros participantes.

Assim, aposta-se cada vez mais no aluno como construtor do conhecimento, tendo ele um papel de extrema importância na sala de aula principalmente como questionador. O professor passa a ser visto como um guia, que deve nortear o aluno no processo de apropriação dos conhecimentos científicos referentes aos fenômenos do 
mundo que o cerca e instigá-lo a levantar possíveis soluções para as situações-problema que venha a encontrar.

Diante desse novo cenário envolvendo a educação, e mesmo mais especificamente o ensino de ciências, uma estratégia que ganha cada vez mais espaço é a promoção de atividades em grupo. Dentro de sala de aula, esta é uma maneira de incentivar a participação dos alunos, pois por meio das atividades coletivas eles interagem uns com os outros e participam de discussões desenvolvendo suas idéias e resolvendo problemas. Essa estratégia permite que se aprenda não apenas o conteúdo específico da disciplina, mas também a argumentar, a escutar e a respeitar opiniões diversas e a colaborar em prol de um objetivo comum.

$\mathrm{Na}$ literatura da área é possível encontrar diversas pesquisas que ressaltam aspectos importantes do trabalho grupal. Para Brown et al. (1989), o trabalho em grupo se faz mais eficiente que o trabalho individual na medida em que promove a cooperação, oferecendo oportunidades para se debater idéias e esclarecer dúvidas. Coll (1992) propõe que sejam ensinadas estratégias de trabalho em equipe na escola. Segundo ele, a interação entre os componentes contribui para o desenvolvimento de um novo conhecimento, tendo em vista que esse desenvolvimento é social. Além disso, quando se trabalha em equipe é necessário expressar-se coerentemente devido às discussões que se fazem necessárias, e aprender a ouvir e respeitar outros pontos de vista.

Duschl (1995) e Wheatley (1991) acreditam que o trabalho em grupo promove uma oportunidade de discussão e argumentação imprescindível no processo de educação científica. Quando argumenta sobre seu ponto de vista o aluno desenvolve mais profundamente a sua compreensão sobre o problema. Kirschner (1992) acredita que o trabalho em grupo seja uma oportunidade de desenvolver as capacidades intelectuais e que compreender como se dão as relações entre os alunos participantes pode ajudar a nortear o professor na escolha de sua intervenção.

Mas não é apenas dentro de sala de aula que o trabalho coletivo pode ser bastante valioso. Podemos ter grupos de professores planejando estratégias e contribuindo para uma integração maior entre as diversas disciplinas. Por exemplo, Weigert et al. (2005) acompanharam o processo de construção de um trabalho interdisciplinar por um grupo de professores numa parceria entre uma escola de Ensino Médio e outras instituições de ensino e pesquisa. 


\section{O que é grupo?}

Antes de continuarmos nossa discussão a respeito dos grupos no ensino, devemos nos perguntar: mas afinal, o que é um grupo? Como diferenciar um agrupamento de pessoas e um grupo?

Pesquisando sobre o assunto, é possível perceber que existem várias possibilidades de abordagem para o tema grupo e diferentes classificações e definições para o termo.

Silva (2000) e Silva (2008), baseados nas obras de Fernández (2006) e Anzieu (1971), fizeram um breve levantamento da origem da palavra grupo para, a partir de sua etimologia, chegar a uma definição para o termo usado em seus trabalhos. Vamos trilhar esse mesmo caminho para definirmos o significado do termo grupo que adotaremos ao longo deste trabalho.

A origem e o uso do termo ainda são pouco conhecidos, mas é curioso que nos idiomas antigos não houvesse termo para reunião de pessoas com objetivo comum.

O vocábulo francês e castelhano têm origem no italiano groppo, que era usado nas belas artes para se referir a um conjunto de pessoas esculpidas ou pintadas.

[...] Groppo aludia a um conjunto de pessoas esculpidas ou pintadas, passando por volta do século XVIII a significar uma reunião de pessoas, e rapidamente seu uso coloquial se espalhou. O groppo scultorico é uma forma artística própria do Renascimento, através da qual as esculturas que em tempos medievais estavam sempre integradas ao edifício passam a ser expressões artísticas em volumes, separadas dos prédios, ao redor das quais é possível caminhar para apreciá-las, ou seja, é possível rodeá-las; muda assim a relação entre o homem, suas produções artísticas, o espaço e a transcendência. Ao mesmo tempo, outra das características do groppo scultorico a ser destacada é que suas figuras ganham mais sentido quando observadas como conjunto do que isoladamente. (FERNÁNDEZ, 2006, p. 17)

Segundo Anzieu (1971) o termo foi usado por escrito pela primeira vez por Molière em um poema (Poème du Val-de-Grâce). Depois dessa utilização a palavra grupo passou a fazer parte da linguagem corrente, usada para designar um conjunto de elementos. Mas foi no século XVIII que o termo groupe, em francês, adquiriu o significado de reunião de pessoas.

A etimologia da palavra está ligada a duas linhas de pensamento: vínculo (ou nó, representando o grau de coesão entre os membros do grupo) e círculo (representando a reunião das pessoas). Adjacente a essas noções está a idéia de igualdade. Como ilustração podemos recorrer à tradição dos Cavaleiros da Távola Redonda, que se 
reuniam com o Rei Arthur em torno de uma mesa circular para que não houvesse distinção hierárquica entre eles, pois todos eram iguais perante o Rei e perante Cristo; e ainda à ordem dos templários, cujo altar circular permitia que todos estivessem à mesma distância de Deus.

Em sua tentativa de definir o termo grupo, Anzieu caracterizou cinco diferentes tipos: multidão, bando, agrupamento, grupo primário e grupo secundário. Essa categorização está pautada no grau de organização a que chegam os grupos. Para este trabalho utilizaremos a noção dos grupos primários caracterizados por Anzieu para designar os grupos que trataremos, portanto, não entraremos em detalhes a respeito das outras categorias. O grupo primário é

[...] formado por um número reduzido de participantes, o que possibilita que a integração entre eles seja grande, favorecendo uma postura mais ativa, em que cada indivíduo assume os objetivos como sendo efetivamente seus e do grupo. Isso traz a noção de coletividade, de "nós", tornando possível o estreitamento dos laços afetivos e da clara interdependência e solidariedade intragrupal, por meio da qual os indivíduos manifestam condutas cooperativas. Há uma organização por meio de normas, crenças rituais e definição de papéis. Existe a preocupação de preservação física e idealizada (imagem) do grupo, de modo que seus participantes têm comportamentos que favorecem o relacionamento e a manutenção do grupo. Destaca-se a importância de comunicação entre seus membros, sem que alguém funcione como intermediário, havendo contato direto entre todos. (SILVA, 2000, p.12)

\section{Monitoria, grupos e psicanálise}

Anteriormente citamos alguns trabalhos que enfatizam os pontos favoráveis da utilização do trabalho em grupo dentro de sala de aula. Mas podemos ainda pensar em reunir alunos fora da sala de aula em pequenos grupos de estudos. E pensando nesse sentido: por que não um grupo de monitores discentes? É possível pensar em um projeto como esse para as escolas: um grupo de alunos que ficariam à disposição de seus colegas para ajudá-los com suas dúvidas. Tratar-se-ia de um projeto inovador dentro da instituição que poderia até mesmo passar a envolver outros professores.

A monitoria discente pode se tornar uma experiência de muitos ganhos. Se temos alunos com facilidade na disciplina e outros que precisam de mais tempo e atenção para compreender a matéria, por que não proporcionar uma oportunidade de esses alunos interagirem e se ajudarem? Dessa forma podemos obter ganhos em termos de aprendizagem, e também ganhos de relação entre pessoas. Participando de um projeto de monitoria, grupos de estudantes, que talvez nunca antes tenham tido um real 
contato além daquele imposto pela proximidade física dentro da sala de aula, podem interagir e aprender a respeitar a diferença, através de um estímulo à cooperação e crescimento mútuos. Dessa forma, o professor tem uma chance de atuar como promotor de interações no ambiente social escolar, criando uma possibilidade de trocas dentro desse ambiente, sendo a moeda de troca estabelecida pelos próprios alunos envolvidos.

Neste trabalho analisamos a trajetória de um projeto que envolvia alguns grupos de alunos monitores que atuavam na disciplina de Física. Essa análise poderia ser pensada por diversos vieses, mas optamos por um que nos permite enxergar os aspectos subjetivos que permeiam o trabalho coletivo. O funcionamento dos grupos acontece em dois planos: um da intencionalidade consciente e outro da interferência de fatores inconscientes, de modo que os grupos são também pautados pelo aparecimento de ansiedades, fantasias, resistências, mecanismos de defesa. Assim, acreditamos que as teorias psicanalíticas de grupo nos fornecem importantes elementos para entender o processo grupal.

Vários autores elaboraram teorias psicanalíticas de grupo que já foram usadas como referencial teórico para pesquisas na área de Ensino de Ciências. A seguir apontaremos algumas pesquisas que fizeram o acoplamento entre as teorias psicanalíticas e o campo educacional e que produziram resultados significativos envolvendo grupos de alunos e / ou professores nos diversos segmentos de ensino (fundamental, médio e superior).

Barros, Laburú e Rocha (2007) investigaram a dinâmica de um grupo de aprendizagem numa aula de ciências do ensino fundamental, utilizando, para análise e interpretação dos dados, referencial teórico de orientação psicanalítica, em especial a Teoria do Vínculo de Pichon-Rivière (1995). No início da investigação o grupo manifestou vínculos negativos, rejeitando um dos membros. A intervenção da professora, na tentativa de promover uma maior interação grupal, buscou uma aprendizagem cooperativa, e em certos momentos deixou os alunos do grupo à vontade para resolverem seus problemas sem tanta interferência. O referencial teórico adotado foi importante para compreender o papel da subjetividade e dos aspectos inconscientes do processo de ensino e aprendizagem, e contribuiu também para repensar a prática educativa, auxiliando o professor no desenvolvimento de competências profissionais para lidar com situações de impasse em sala de aula.

Sanchez (2002) explorou o modelo de grupos operativos proposto por Enrique Pichon-Rivière (1994) ao analisar grupos de alunos do ensino médio resolvendo tarefas 
de Física no laboratório. Já Silva (2008) analisou três grupos de alunos do ensino médio durante aulas de resolução de exercícios. Em especial ele analisou as intervenções do professor e seus efeitos na dinâmica grupal, entre as quais uma se destaca: a que atribuiu funções rotativas aos membros do grupo (líder, anotador e questionador). Utilizando conceitos da teoria de grupos operativos foi possível determinar características de cada grupo que permitiram classificá-los como grupos da mudança, da resistência e da dependência. $\mathrm{O}$ autor discutiu as características de cada grupo levantando alguns fatores que julga importantes para o processo: o próprio grupo enquanto organização, as intervenções do professor e as funções introduzidas e a tarefa explícita que revelava a relação dos estudantes com o conhecimento físico.

Julio e Vaz (2005) recorreram aos conceitos psicanalíticos de Grupo de Trabalho desenvolvidos por Bion (1975) e também ao conceito de Grupo Operativo, desenvolvido por Pichon-Rivière (1994). Com o intuito de analisar uma situação de aprendizagem em que grupos de alunos participavam de uma atividade de investigação guiada pelo professor, os autores se valeram dos conceitos psicanalíticos citados como apoio para estudar o comportamento do que chamaram de Grupos Pequenos e Grupo Grande, sendo este uma plenária envolvendo todos os alunos que participavam daqueles. Os Grupos Pequenos, nos quais os alunos foram distribuídos, realizavam tarefas específicas, atendendo a objetivos cognitivos - por exemplo, perceber que o fenômeno estudado era relacionado a estrelas -, enquanto o Grupo Grande, composto pela classe mais o professor, era voltado para objetivos educacionais mais amplos como estabelecer uma metodologia de investigação sobre o fenômeno observado - e regido pelo professor. Os autores analisaram os Grupos Pequenos conforme os Grupos de Trabalho de Bion, investigando como a ação do professor contribuía para que se articulassem em torno da tarefa. Já o Grupo Grande foi analisado do ponto de vista de um Grupo Operativo, de modo a verificar o tipo de intervenção realizada pelo professor e os efeitos que elas causaram na condução dos trabalhos dentro dos Grupos Pequenos e em sua interação com o Grupo Grande.

Barros e Villani (2004), em seu estudo sobre dois grupos de alunos de Física do Ensino Médio que participaram de duas disciplinas ministradas pelo mesmo professor, adotaram como referencial teórico a obra de Anzieu (1993) sobre grupos, também de orientação psicanalítica. Apesar de tanto o professor como a escola e o conteúdo trabalhado terem sido os mesmos para os dois grupos, o êxito que o primeiro grupo experimentou ao término da experiência não foi repetido pelo segundo grupo. Uma das 
falhas junto ao segundo grupo, por parte do professor, foi desejar que o segundo atuasse como um grupo operativo desde o início da experiência, situação que o primeiro grupo atingiu somente ao final da experiência correspondente por meio de intervenções adequadas do professor que visavam esse objetivo.

Barolli (1998) utilizou as idéias de Grupo de Trabalho e Grupo de Suposições Básicas, desenvolvidas pelo inglês W. R. Bion (1975), para analisar grupos de alunos em um laboratório didático de Física no ensino superior. Ela focalizou os aspectos que estavam associados ao modo como os grupos se estruturaram, ou seja, aos vínculos que foram se estabelecendo ao longo do processo entre os componentes, o professor e a tarefa. Assim, foi possível perceber que algumas posturas do grupo podem desviá-lo do objetivo da tarefa, e que a sua dinâmica pode ser pautada por aspectos objetivos ou por aspectos subjetivos, como emoções, que influenciam seu comportamento e sua disponibilidade para a tarefa.

A perspectiva do trabalho de Valadares (2002) é de compreender, descrevendo e interpretando, as relações estabelecidas entre os professores na construção de projetos coletivos e interdisciplinares. Com esse objetivo, ele adaptou a teoria de René Kaës (1991, 1997) para interpretar os avanços e retrocessos do grupo de professores que decidiu trabalhar coletivamente nessa nova perspectiva educacional em sua escola.

Valadares e Villani (2003) também utilizaram o referencial de René Kaës (1997) em uma análise dos diferentes graus de evolução grupal dentro do trabalho didático em grupos, por meio do estudo dos relatos de quatro experiências de educação em ciências. As experiências tratavam de diferentes grupos de alunos em sala de aula e de um grupo de professores que promoviam a construção de projetos interdisciplinares com alunos do ensino fundamental. Os quatro episódios relatados constituíram uma amostra das possibilidades de desenvolvimento de um grupo: um deles não conseguiu ultrapassar a serialidade; outro encontrou uma solução para um problema surgido e se estabilizou; um terceiro foi além, pois conseguiu reverter um quadro de estereotipia de papéis que proporcionou a troca de lideranças; e o último conseguiu atingir o pleno desenvolvimento da criatividade grupal. Os conceitos da teoria de Kaës ajudaram a caracterizar as diferenças entre eles e permitiram entender as falhas e sucessos na estruturação grupal a partir do conceito de intermediário. Com isso os autores concluem que este referencial pode ser frutífero para descrever e interpretar as várias possibilidades de evolução grupal de grupos de aprendizagem levando em conta as particularidades de cada contexto. 
Weigert et al. (2005) analisaram um grupo de professoras mobilizadas em torno do trabalho de construir um planejamento interdisciplinar, apesar dos conflitos e das dúvidas quanto às possibilidades de êxito. Para tanto se valeram da teoria de Kaës, para estudar os momentos do desenvolvimento grupal neste caso e assim analisaram diversos fatores que promoveram ou atrapalharam o trabalho coletivo.

Enquanto que nos trabalhos já citados, uma situação educacional específica foi analisada à luz de alguma das teorias de grupo de cunho psicanalítico, o trabalho de Silva (2000) traz um levantamento das teorias de grupo desenvolvidas no campo da psicologia clínica e social com o objetivo de secretar contribuições para o campo educacional, especialmente no que se refere à relação estabelecida entre o professor e o grupo de alunos. Seu estudo indica a necessidade de mudança da relação dual professoraluno para uma grupal professor-grupo de alunos e que é necessário o conhecimento da dimensão grupal para melhor lidar com situações que envolvam trabalho coletivo.

Assim, acreditamos que a principal vantagem de utilizarmos conceitos psicanalíticos na pesquisa de grupos de aprendizagem seja a possibilidade de compreensão da dinâmica grupal, considerando aspectos mais subjetivos a respeito das relações que se estabelecem (entre os membros, deles com a tarefa e com a instituição) e a respeito do contexto no qual estão inseridos.

Para analisar os eventos ocorridos com o grupo de monitoria que acompanhamos optamos por adotar o referencial de grupos operativos de Pichon-Rivière, pois os conceitos desenvolvidos por ele nos permitem entender as relações que os membros do grupo estabeleceram entre si e com a tarefa.

\section{A SEQÜÊNCIA}

Neste primeiro capítulo, justificamos a escolha do tema de trabalho e apresentamos uma breve revisão bibliográfica sobre trabalhos da área de interesse.

No capítulo 2, falamos da pesquisa, quais nossos objetivos, metodologia e o contexto em que foram feitas as coletas de dados.

No capítulo 3, apresentamos o referencial teórico utilizado para guiar nossa análise dos dados coletados. Discutiremos alguns dos principais conceitos da teoria de grupos operativos de Pichon-Rivière que nos auxiliarão na compreensão das dinâmicas grupais estabelecidas. 
Nos capítulos 4, 5 e 6 relatamos os eventos que marcaram o desenvolvimento dos grupos de monitores que fizeram parte do projeto de monitoria ao longo de seus cinco anos de existência. Ainda, uma análise da dinâmica grupal de cada edição é feita, relacionando os eventos ocorridos ao longo de cada ano e as entrevistas feitas com os participantes da monitoria. O capítulo 4 se refere às três primeiras edições do projeto, quando ainda não estávamos presentes no campo de pesquisa e, portanto, suas narrativas foram construídas a posteriori. Os capítulos 5 e 6 se referem aos dois últimos anos do projeto, que acompanhamos mais sistematicamente. Nesses três capítulos procuramos levantar características marcantes de cada grupo e identificar como eles encararam a tarefa proposta.

Finalmente, nas Considerações Finais, fazemos uma discussão sobre como as características de cada grupo influenciaram na trajetória do projeto naquela instituição. Ainda, discutimos a validade do projeto analisado e levantamos pontos importantes e questões a serem investigadas sobre a inserção de projetos inovadores em uma instituição escolar. 


\section{Capítulo 2}

\section{A Pesquisa}

A pesquisa ocorreu em uma escola particular da cidade de São Paulo, na qual, durante cinco anos, o professor de Física desenvolveu um projeto de monitoria discente. A idéia desse projeto era que os alunos monitores atuassem ajudando seus colegas na disciplina de Física. Essa ajuda poderia acontecer a qualquer momento, dentro de sala de aula ou fora dela, ou ainda no "plantão de dúvidas", que se tratava de um horário no contra-turno em que dois dos monitores ficavam à disposição para esclarecer as dúvidas de seus colegas.

A organização da monitoria discente era feita por meio de reuniões semanais de aproximadamente uma hora, das quais participavam o professor e todos os monitores. As reuniões tinham o objetivo de discutir os rumos do projeto de monitoria, quais seriam as atividades, a forma com que seriam desenvolvidas e as dificuldades encontradas. Além dos plantões de dúvidas, os monitores colaboravam com o professor relatando, durante essas reuniões, quais eram as perspectivas e dificuldades dos alunos, e também ajudavam no desenvolvimento de atividades que seriam propostas para a turma, opinando ainda sobre o momento em que essas atividades seriam propostas.

O projeto de monitoria foi concebido e implantado pela primeira vez em 2002. A partir daí a experiência teve continuidade nos anos seguintes: 2003 e 2004. Em todas essas edições o professor criador do projeto ministrava aulas para o primeiro ano do ensino médio, portanto, a cada ano, havia uma equipe de monitores diferente. Em 2005 e 2006 o professor ministrou aulas para o terceiro ano do ensino médio, fazendo com que naqueles anos a monitoria acontecesse em um contexto completamente diferente, com uma série de desafios novos. Sendo assim, o professor e os monitores constituíam um grupo de monitoria diferente a cada novo ano. $\mathrm{O}$ foco de nossa pesquisa é o projeto de monitoria discente de Física desenvolvido pelos diversos grupos formados ao longo de seus cinco anos de existência.

\section{OBJETIVOS}

Iniciamos esclarecendo de onde veio nossa motivação para pesquisar a monitoria discente. Era início de 2005 e tivemos contato com o relato desse professor sobre o modelo de monitoria que havia proposto à escola onde trabalhava e os resultados que 
estava obtendo, desde 2002, através desta experiência. Nosso interesse inicial era pesquisar a dinâmica de grupos no ensino e, ao saber dos bons resultados relatados pelo professor, nos interessamos em estudar a dinâmica de desenvolvimento do grupo de monitores daquele ano. Nosso interesse principal era pesquisar a evolução do grupo, como lidavam com os problemas que apareciam e como davam os saltos qualitativos (como nomeia Pichon-Rivière, conforme veremos a seguir, em nossa apresentação do referencial teórico adotado) rumo a uma configuração de maior autonomia.

Acompanhando o grupo de 2005, não obtivemos os resultados que imaginávamos: o grupo não evoluiu como nas experiências anteriores, ele ficou estagnado em uma situação de manutenção do espaço da monitoria, sem criatividade e sem resolução de conflitos (o que ficará claro nos capítulos posteriores). Assim, mudamos o foco de nossa pesquisa: passamos a nos interessar pelo projeto de monitoria e como os grupos se desenvolviam ao longo das suas edições. Para tanto, acompanhamos ainda o grupo formado em 2006 e recorremos ao relato do professor a respeito das edições anteriores: 2002, 2003 e 2004.

Considerando que sabíamos do sucesso já alcançado pela monitoria, com grupos criativos e que conseguiam resolver os problemas surgidos, e tendo constatado um comportamento diferente dos grupos que observamos, formulamos algumas questões que nortearam esse trabalho:

- Como cada grupo de monitoria se sustentou? Como se deu a dinâmica grupal? Quais fatores contribuíram para a permanência dos sujeitos no projeto?

- Como as características de cada grupo influenciaram a trajetória do projeto dentro da instituição?

- Quais fatores contribuíram para a ascensão do projeto? E quais influenciaram seu declínio?

\section{Metodologia}

Para esta pesquisa foi utilizada a metodologia da pesquisa qualitativa. Trata-se de uma investigação com ênfase nas informações qualitativas e nos enfoques interpretativos, sendo que o foco da pesquisa não se encontra apenas nos resultados finais, mas principalmente no processo que envolve o dinamismo dos grupos e conseqüentemente do projeto. 
Assim, a "pesquisa qualitativa é o termo que vem sendo usado alternativamente para designar várias abordagens à pesquisa em ensino, tais como pesquisa etnográfica, participativa observacional, estudo de caso [...]. Cada uma delas forma um todo coerente englobando suposições internamente consistentes sobre natureza humana, sociedade [...]”. (MOREIRA, 1990, p. 32).

As escolhas e encaminhamentos desta pesquisa foram feitas com base em uma metodologia que privilegia um recorte de pesquisa que focaliza as diferentes formas de relação que os sujeitos adotam frente ao conhecimento, e focaliza também os condicionantes subjetivos que fazem com que essa relação se estabeleça daquela forma, pelo menos naquele momento de sua história (VILLANI et al, 2006).

Para tanto, buscam-se situações concretas que possam ser analisadas por um referencial psicanalítico, permitindo a interpretação dos eventos também em uma dimensão subjetiva, e não apenas cognitiva. Podemos explicitar melhor a metodologia utilizada dividindo-a em três fases principais: a escolha do caso, a coleta dos dados e a análise. Nas subseções seguintes apresentaremos como nossa pesquisa se desenvolveu dentro dessa metodologia.

\section{A Escolha do Caso}

O primeiro passo de nosso processo investigativo é localizar alguma experiência que traga a possibilidade de produção de um novo conhecimento. Assim, primeiramente, escolhemos uma situação que carrega alguma novidade objetiva e que acreditamos ser caracterizada por uma configuração de natureza subjetiva que possa ser compreendida.

No caso desta pesquisa, a monitoria discente constituía uma experiência inovadora passível de ser investigada pelo viés da subjetividade, uma vez que nos interessávamos por questões relacionadas à sustentação e desenvolvimento dos grupos, pela dinâmica estabelecida entre os seus participantes e de que forma esses e outros fatores influenciaram a trajetória do projeto.

Outro aspecto importante da escolha do caso a ser estudado é a possibilidade de sua descrição por meio de uma narrativa que marca os momentos de dificuldade, de sucesso e mesmo fases que explicitem o processo. Essa narrativa, que é construída nas fases iniciais da pesquisa, pode ser feita de duas formas principais: pela reconstrução posterior dos eventos ou pelo acompanhamento on line da nova experiência. 
Para esta pesquisa, acoplamos os dois modos de pesquisa, pois optamos por abranger eventos anteriores $(2002,2003$ e 2004) e posteriores (2005 e 2006) à nossa entrada no campo de pesquisa. Então, construímos cinco narrativas (uma para cada ano), de modo que as três primeiras são reconstruções dos eventos baseadas em um relato do professor e as duas últimas são produto do acompanhamento on line dos eventos ligados à monitoria. Dessa forma, nos dois últimos anos, íamos construindo a narrativa durante a realização da experiência, o que permitiu que pudéssemos a todo instante nos questionar sobre as situações e planejar formas de coleta de dados (entrevistas, por exemplo) que dessem conta de explicitar melhor as dúvidas que surgiam.

\section{Coleta de Dados}

Como optamos por uma metodologia que se apóia nos procedimentos da pesquisa qualitativa ao mesmo tempo em que se propõe a explorar um referencial de análise psicanalítico, foi preciso coletar os dados de forma a proporcionar uma riqueza de detalhes. Dessa forma, o registro dos dados precisou ser feito por vários meios diferentes: gravações em vídeo/ áudio, entrevistas, registros escritos dos participantes da experiência e notas de campo do pesquisador.

A utilização simultânea dessas várias formas de registro dos dados permite ampliar as informações consideradas na construção da narrativa histórica da experiência. O acoplamento de todos esses registros é um processo longo e complexo, mas que se torna muito vantajoso pela multiplicidade de indícios e pelas possibilidades de triangulação e verificação mútua ao longo do processo de construção da narrativa e, posteriormente, de análise.

A primeira parte de nossos dados, referentes aos eventos da monitoria nos anos anteriores à nossa entrada no campo de pesquisa, foi obtida através de um relato detalhado do professor. Como ele também desenvolvia uma pesquisa durante aquele tempo, seu relato é permeado por trechos de entrevistas com os monitores e respostas de questionários formulados por ele.

A nossa coleta de dados ocorreu em duas etapas: uma delas de abril a novembro de 2005, tendo seu início na segunda reunião do grupo e final na última reunião do ano; e a segunda etapa de abril a novembro de 2006 , tendo seu início na quarta reunião do grupo e final na última reunião do ano. Os alunos participantes do grupo de monitoria 
nos anos de 2005 e 2006 não eram os mesmos, tendo em vista que se tratava de grupos de alunos de terceiro ano de Ensino Médio.

Para tanto, foi utilizada a técnica da observação participante, de cunho etnográfico, onde a pesquisadora permaneceu no ambiente de pesquisa durante os eventos fazendo notas de campo, pois estas permitem a reconstrução dos eventos mais significativos ocorridos durante o trabalho do grupo. O recurso da gravação em vídeo também foi utilizado, pois as gravações dos alunos podem fornecer subsídios mais detalhados para acompanhar o trabalho dos grupos.

A pesquisa não utilizou a gravação em vídeo durante os seis primeiros encontros do grupo de 2005, pois durante esse tempo estavam sendo tomadas providências para a permissão de sua utilização. Os primeiros encontros foram registrados apenas nas notas de campo da pesquisadora. A partir do segundo semestre, começaram as gravações audiovisuais, que ocorriam com a câmera fixa, sob operação da pesquisadora que a girava de forma a ser possível observar todos os participantes e gravar suas falas e comportamento gestual.

Os encontros ocorreram uma vez por semana, após a última aula do período da manhã e tiveram duração de aproximadamente uma hora.

Além das gravações em vídeo e das notas de campo também foram coletados dados por meio de entrevistas semi-estruturadas com os monitores e o professor. No ano de 2005 foram realizadas entrevistas em dois momentos: uma na metade do ano, e outra no encerramento das atividades de monitoria.

Em junho daquele ano fizemos uma entrevista narrativa com o professor a fim de reconstruir as bases do projeto de monitoria e perceber suas expectativas para o ano corrente. Foi feita também uma entrevista semi-estruturada com todos os monitores buscando entender o que os motivava a participar do projeto e qual a importância que eles davam ao trabalho em equipe durante as reuniões.

No fim do ano de 2005 a entrevista se dividiu em duas partes: uma individual, com todos os monitores, e outra em grupos de três monitores, de forma que todos participaram. Essa entrevista foi mais longa, pois teve a intenção de obter as impressões dos alunos sobre vários aspectos da monitoria e sobre eventos específicos que ocorreram ao longo do ano. A idéia de fazer também uma entrevista coletiva se deu pela expectativa de que em conjunto pudessem aparecer novos elementos que não seriam explicitados nas entrevistas individuais, e também para tentarmos obter mais pistas sobre o relacionamento dos monitores entre si. 
Já no ano de 2006, as entrevistas com os monitores foram todas individuais e foram realizadas apenas no encerramento das atividades, com o objetivo de uma sondagem maior e uma melhor compreensão dos eventos. Dessa forma, houve mais elementos para a redação da narrativa fazendo uma reconstrução histórica do grupo. Ainda nesse ano foi realizada mais uma entrevista com o professor a fim de obter informações sobre suas expectativas e o andamento do grupo de monitoria.

\section{Análise de dados}

Entre a coleta de dados e sua análise, nossa pesquisa passa por uma fase intermediária em que se tenta dar sentido aos dados sem a intervenção de um referencial teórico. Com isso, procuramos definir os eventos mais marcantes no processo e delinear o tipo de história que os dados permitem contar. Dessa forma, podemos propor perguntas aos dados e, cruzando as diferentes evidências obtidas através das filmagens, entrevistas e diário de campo, podemos reconstruir sua história levando em conta os aspectos subjetivos que permeiam o processo.

Feita a reconstrução histórica, são realizadas discussões de sínteses parciais do processo com o grupo de pesquisa. A contribuição do grupo é a de levantar questionamentos e hipóteses que ajudem o pesquisador a apurar seu olhar sobre os dados.

A partir daí é preciso escolher um referencial teórico que incorpora o papel da subjetividade e sua influência na experiência a ser analisada. A escolha do referencial tem a perspectiva de avançar nas interpretações preliminares, possibilitando a construção de novos conhecimentos.

Em nosso caso, decidimos trabalhar com as idéias de Pichon-Rivière sobre grupos operativos para analisar as relações que cada grupo estabeleceu com a tarefa. Entendemos que, uma vez que nos preocupávamos com a trajetória do projeto de monitoria ao longo do tempo, precisávamos analisar como cada grupo encarou a tarefa de ajuda aos colegas. Nessa perspectiva, Pichon-Rivière aponta elementos da dinâmica grupal importantes para nosso estudo.

Uma característica essencial do processo de análise de dados dentro desta metodologia é a participação de um grupo de pesquisadores no debate dos dados obtidos e análises preliminares. Cada pesquisador do grupo narra a situação investigada e alguns resultados obtidos por ele, e os outros pesquisadores, que não participaram da experiência analisada, levantam questões e sugerem hipóteses a partir do referencial 
adotado. $\mathrm{O}$ distanciamento dos dados permite que os pesquisadores do grupo enxerguem a totalidade do trabalho e ajudem na busca de sua lógica e coerência. Ainda, é possível que os pesquisadores contribuam através da identificação de ressonâncias com outros referenciais teóricos conhecidos por eles.

A intenção de envolver o grupo de pesquisa no processo de análise dos dados é "ir encadeando acontecimentos aparentemente desconectados, e colocando elos nos impasses vividos e lacunas geradas em busca de uma interpretação eficaz, mesmo que relativa." (VILLANI et al, 2006, p. 336).

Neste momento, o grupo trabalha de maneira positiva, dando muito mais ênfase às sugestões do que às críticas. Dessa forma, há um constante contato entre o pesquisador e o grupo de pesquisa, desenvolvendo e aprimorando as interpretações das situações analisadas. 


\section{Capítulo 3}

\section{GRUPOS OPERATIVOS}

A teoria de grupos operativos, que norteará nosso olhar para este trabalho, foi desenvolvida por Enrique Pichon-Rivière, psicanalista suíço que morou na Argentina durante quase toda sua vida. Sua vivência na Argentina despertou seu interesse pelas relações sociais. Ao se mudar de Genebra para Chaco, aos quatro anos de idade, Pichon vivenciou dois modelos culturais bastante diferentes: o europeu, preservado por sua família, e o argentino, que ele classifica como "primitivo". A observação da nova cultura na qual estava inserido, e que divergia daquela herdada por meio de suas raízes européias, despertaram seu interesse pela observação da realidade: “[...] Meu interesse pela observação da realidade teve, inicialmente, características pré-científicas e, mais exatamente, místicas e mágicas, adquirindo uma metodologia científica através da prática psiquiátrica." (PICHON-RIVIÈRE, 1994, p. VIII).

Vivendo entre populações rurais influenciadas pela cultura indígena, Pichon conviveu com uma concepção de mundo de caráter mágico, muito marcada pela mitologia guarani. Suas observações e vivências da infância e juventude foram determinantes para o desenvolvimento de suas idéias, que culminaram em uma teoria que explora a relação dialética entre o homem e seu meio:

O interesse pela observação dos personagens prototípicos, que nas pequenas populações adquirem uma significância particular, estava orientado, ainda não conscientemente, para a descoberta dos modelos simbólicos, através dos quais torna-se manifesto o interjogo de papéis que configura a vida de um grupo social em seu âmbito ecológico. (PICHON-RIVIÈRE, 1994, p. VIII)

Para Pichon, a psiquiatria atual é uma psiquiatria social, pois não é possível separar o indivíduo da sociedade. Os pensamentos e idéias de cada pessoa são uma representação particular e individual de como o mundo é captado, de acordo com a história pessoal de cada uma e de como o meio atua sobre ela. Dessa forma, o mundo é entendido por cada um através de uma fórmula pessoal.

A psicologia social tem como objeto de estudo a relação entre a estrutura social e a configuração do mundo interno do sujeito. Nessa perspectiva, o homem é um ser de necessidades que só são satisfeitas socialmente em relações que o determinam. O sujeito 
é produzido em uma práxis, sendo a resultante da interação entre indivíduo, grupos e classes.

Existem três dimensões de análise das relações entre o sujeito e seu meio social: a psicossocial (que parte do indivíduo para fora, refere-se às relações do sujeito com cada um dos membros do grupo ao qual pertence), a sociodinâmica (que analisa o grupo como estrutura, em sua totalidade, considerando as diferentes tensões entre todos os objetos que configuram a estrutura do grupo) e a institucional (que aborda o grupo como uma instituição, através do estudo de sua história e de suas relações intergrupais). Não existe uma separação clara entre esses campos de investigação, eles se integram sucessivamente. Assim, o campo operacional da psicologia social é o grupo, pois este permite a investigação do interjogo entre as três possíveis dimensões de análise.

A teoria e a técnica de grupos operativos começou a ganhar corpo a partir de uma experiência vivida por Pichon-Rivière no hospital psiquiátrico De Las Mercês, em Rosário, onde trabalhava como médico e professor. O pessoal da enfermagem do hospital entrou em greve; para atender os enfermos diante daquela situação crítica, ele colocou os pacientes menos comprometidos para tomar conta dos mais comprometidos.

Com a ruptura de papéis estereotipados, através do estabelecimento de novas funções para esses pacientes, e do novo processo de comunicação estabelecido, houve significativa melhora tanto daqueles que foram cuidados, como daqueles que cuidaram de seus colegas.

Os resultados obtidos com essa experiência e os estudos de Pichon-Rivière sobre fenômenos grupais a partir da psicanálise de Freud e Melanie Klein, da teoria de campo de Kurt Lewin e da teoria de Comunicação e Interação foram determinantes para se chegar a um corpo teórico consistente acerca do funcionamento grupal e que toma como referência a relação entre a doença mental e o grupo familiar do paciente.

Até então, a psiquiatria tinha uma concepção endógena da doença mental, ou seja, uma visão de que a doença é inerente ao indivíduo, tendo sua origem em causas intrínsecas ao sujeito. Uma visão oposta a essa seria a de uma concepção exógena - a de que a origem da doença é externa ao paciente. Pichon-Rivière propôs uma concepção dialética da doença, ou seja, que existe uma inter-relação entre o mundo interno do sujeito e a estrutura social na qual ele está inserido.

Em sua teoria, um grupo operativo é um “[...] conjunto de pessoas reunidas por constantes de tempo e espaço, articuladas por sua mútua representação interna, que se propõem, implícita ou explicitamente, uma tarefa que constitui sua finalidade." 
(PICHON-RIVIÈRE, 1994, p. 157). Esta tarefa pode ser de aprendizagem, diagnóstico ou cura.

Para ele, aprendizagem significa desenvolver uma leitura crítica da realidade para uma adaptação ativa à vida. A todo momento são encontradas dificuldades na realização da tarefa grupal, o que requer discussão e o estabelecimento de estratégias para superar essas dificuldades. Aprender, conforme a teoria pichoneana, é sinônimo de mudança.

Toda mudança provoca ansiedades caracterizadas por dois medos básicos: o medo de perder o já estabelecido e conhecido e o medo do desconhecido, do que está por vir, mas ainda não é. Portanto essas ansiedades estão a serviço da resistência à mudança. A atividade do grupo consiste em mobilizar as dificuldades geradas por essas ansiedades, uma vez que a realização de qualquer tarefa nova exige a modificação de padrões de funcionamento.

As relações interpessoais dentro do grupo são determinadas por uma dinâmica entre papéis assumidos e adjudicados. Existe sempre um interjogo dialético entre a assunção de um determinado papel e a adjudicação de um papel a outra pessoa. "Na medida em que um adjudica e o outro recebe, estabelece-se entre ambos uma relação que denominamos vínculo. Este tende a se desenvolver dialeticamente chegando a uma síntese dos dois papéis, que é o que dará as características do comportamento tanto do indivíduo quanto do grupo considerado" (PICHON-RIVIÈRE, 1995, p.129).

Quando os papéis ficam estereotipados, o grupo "patina" e não consegue avançar rumo à concretização de seu objetivo. É importante que as relações se estabeleçam de forma que haja uma plasticidade nos papéis, o que caracteriza uma disposição ao enfrentamento das dificuldades e realização da tarefa.

Através da elaboração ${ }^{2}$ das ansiedades o grupo caminha para o projeto, deixando de ser espectador e se tornando protagonista, vencendo as dificuldades com criatividade e planejando ações futuras.

Nesta proposta, podemos falar em teoria e técnica de grupos operativos. A técnica trata dos procedimentos a serem adotados na tentativa de levar um grupo à operatividade; ou seja, é uma forma de trabalho com grupos que visa promover, de

\footnotetext{
${ }^{2}$ Elaboração psíquica - expressão usada por Freud para designar, em diversos contextos, o trabalho realizado pelo aparelho psíquico com o fim de dominar as excitações que chegam até ele e cuja acumulação ameaça a ser patogênica. Este trabalho consiste em integrar as excitações no psiquismo e em estabelecer entre elas conexões associativas. (LAPLANCHE \& PONTALIS, 1988; p. 196)
} 
forma econômica, um processo de aprendizagem. Já a teoria trata de conceitos desenvolvidos dentro da psicologia social e que fundamentam a técnica.

Neste trabalho trataremos da teoria de grupos operativos. Assim, discutiremos os principais conceitos desenvolvidos por Pichon-Rivière para, nos capítulos seguintes, utilizá-los como forma de compreender os processos pelos quais os grupos de monitores que acompanhamos passaram. Portanto, é importante enfatizar que não aplicamos a técnica de grupos operativos com os estudantes, mas vamos utilizar a teoria como referencial teórico de análise dos eventos que marcaram o desenvolvimento dos grupos que participaram do referido projeto de monitoria discente de Física.

\section{GRUPOS CENTRADOS NA TAREFA}

\section{Idéias-base}

Segundo Bleger (2003, p. 59):

o grupo operativo [...] é um conjunto de pessoas com um objetivo comum que procuram abordar trabalhando como equipe. A estrutura de equipe só se consegue na medida em que opera; grande parte do trabalho do grupo operativo consiste, em resumo, no treinamento para trabalhar como equipe.

No campo do ensino, a operatividade do grupo está relacionada com a aprendizagem. No entanto, tal aprendizagem vai além da assimilação do conteúdo disciplinar, ela se inicia no desenvolvimento da capacidade de resolução das ansiedades ligadas à aprendizagem dessa disciplina.

Ao dizer que a estrutura de equipe é alcançada na medida em que opera, Bleger explicita que o grupo "prepara-se para aprender e isto só se alcança enquanto aprende, quer dizer, enquanto se trabalha”. (BLEGER, 2003, p. 59).

Ao longo do trabalho em torno de seu objetivo comum surgem problemas, conflitos e ansiedades que devem ser considerados e discutidos pelo grupo à medida que aparecem, buscando utilizar os recursos de que dispõem para superá-los, de acordo com a tarefa proposta.

Diante desta abordagem, desenvolvemos um olhar para o grupo que vai além de sua vinculação técnica com a tarefa, pois analisamos as relações estabelecidas entre seus membros e destes com a atividade a que se propõem. Enquanto um grupo de ensino, por exemplo, desenvolve um tópico de estudo dado, também se forma nos diferentes aspectos do fator humano. Desta forma, analisamos um espectro de elementos 
subjetivos que constitui o fator humano de um trabalho grupal em torno de uma tarefa objetiva.

Opomo-nos à velha ilusão, tão difundida, de que uma tarefa é mais bem realizada quando são excluídos os chamados fatores subjetivos e ela é considerada apenas "objetivamente"; pelo contrário, afirmamos e garantimos, na prática, que o mais alto grau de eficiência em uma tarefa é obtido quando se incorpora sistematicamente a ela o ser humano total. (BLEGER, 2003, p. 60)

\section{A tarefa}

Dizemos que os grupos operativos são grupos centrados na tarefa, tendo por finalidade aprender diante das dificuldades surgidas no campo grupal. Tal tarefa possui duas dimensões: uma explícita e uma implícita. Por tarefa explícita entendemos aquela que constitui o objetivo formal do grupo, aquele em torno do qual ele se reuniu, que pode ser a aprendizagem, a cura, a criação publicitária etc. Já a tarefa implícita está associada à ruptura, e o trabalho sobre ela visa à manutenção da coesão do grupo durante a realização da tarefa explícita. Ao longo do trabalho surgem ansiedades e dificuldades que tendem a dificultar a comunicação e, conseqüentemente, a realização da tarefa explícita. Ao se debruçar sobre a tarefa implícita o grupo trabalha em torno de aliviar essas ansiedades, contribuindo para o seu não-desmantelamento diante das dificuldades.

\section{O vínculo}

O vínculo é um conceito central na teoria pichoneana e aborda as relações existentes entre os sujeitos e os objetos que o cercam durante o processo de interação: “[...] Definimos o vínculo como a estrutura complexa que inclui o sujeito e o objeto, sua interação, momentos de comunicação e aprendizagem, configurando um processo em forma de espiral dialética [...].” (PICHON-RIVIÈRE, 1994, p. 48).

Assim, Pichon construiu uma Psiquiatria do Vínculo, ou seja, uma psiquiatria das relações interpessoais, que toma como base a maneira como cada indivíduo se relaciona com os outros, criando uma estrutura particular a cada momento, chamada de vínculo (PICHON-RIVIÈRE, 1995).

O vínculo estabelecido pelo indivíduo pode ter diversas configurações, indo daquele denominado normal até o estabelecimento de vínculos patológicos. Num grupo operativo pretende-se a mobilização de estruturas internas dos sujeitos visando à superação de obstáculos e problemas na comunicação. 
O mundo interno do sujeito tenta fazer a reconstrução da realidade externa, mas muitas vezes existem diferenças entre o cenário exterior e aquilo que foi internalizado pelo sujeito. Pichon, no início de suas investigações, voltou seu olhar para o tipo de vínculo que era estabelecido entre o paciente e sua família, o que permitiu que ele concluísse que existia uma relação causal entre a dinâmica do grupo familiar e o mundo interno do paciente. Portanto, o tipo de vínculo estabelecido entre os sujeitos é determinante para o desenvolvimento grupal.

Vínculo e Tarefa são os princípios organizadores de um grupo operativo. Para alcançar a operatividade e, portanto, a superação das dificuldades e a conseqüente aprendizagem, é essencial que o grupo esteja centrado em uma tarefa e que tenha como base a construção de vínculos. Além disso, as tarefas explícita e implícita andam lado a lado na busca da resolução das ansiedades provocadas por toda situação de novidade em busca dos objetivos explícitos. Como afirma Silva (2008, p. 47):

No que diz respeito à tarefa, há uma complementaridade entre suas dimensões: somente a realização da tarefa explícita levaria o grupo a uma completa desordem, o que poderia desintegrá-lo e por outro lado, somente a realização da tarefa implícita não teria sentido e se configuraria em um simples encontro de pessoas, pois é a primeira que funda o grupo.

\section{A DINÂMICA GRUPAL}

\section{Ansiedades básicas}

O grupo é fundado com a tarefa e cabe aos seus membros, em conjunto, trabalhar para resolver as questões objetivas colocadas. No entanto, não é possível a realização da atividade proposta sem que haja mudança, e diante da exigência de mudanças o indivíduo pode se posicionar a favor ou contra ela.

Quando adota uma atitude favorável, ele aceita enfrentar a necessidade de mudar. Já a atitude contrária é adotada quando o sujeito é tomado por uma resistência inconsciente à realização da tarefa que aparece devido às ansiedades e medos provocados pela nova situação.

Diante da situação de resistência à mudança surgem as ansiedades básicas: medo da perda e medo do ataque. O medo da perda, também chamado de ansiedade depressiva, caracteriza-se pelo receio de abandonar o vínculo anterior, aquilo que já está estabelecido, que já foi conquistado, uma maneira conhecida de fazer ou pensar. O medo do ataque, também chamado de ansiedade paranóide, caracteriza-se pelo receio 
em relação ao vínculo novo e pela conseqüente insegurança; é o medo do desconhecido, do perigo que se pode estar correndo, da insegurança por carência de instrumentação.

A proposta de Pichon é que o grupo mobilize essas ansiedades, rompendo estruturas estereotipadas que surgem em função dos medos básicos, permitindo assim o esclarecimento, a comunicação e a aprendizagem. É nesse sentido que dizemos que o grupo é centrado na tarefa, pois deve elaborar e superar essas ansiedades enquanto opera a tarefa.

\section{Papéis assumidos e adjudicados}

No acontecer grupal dos grupos operativos, a assunção e a adjudicação de papéis são mecanismos fundamentais, pois o grupo se estrutura sobre a base de um interjogo de papéis. As redes vincular e de comunicação são constituídas em função dos papéis assumidos e adjudicados entre os membros do grupo.

O papel é uma função particular que o sujeito desempenha ou tenta fazer chegar ao outro. Em nossa vida sempre assumimos e adjudicamos papéis aos outros. Inclusive, cada um de nós pode assumir vários papéis ao mesmo tempo, como de aluno na escola, filho em casa, amigo nas relações sociais etc. A assunção desses papéis pode acontecer por dois tipos de processos: em um deles o sujeito assume um papel consciente e voluntariamente; no outro, quando o ambiente ou os outros adjudicam um determinado papel, ele pode assumi-lo de forma inconsciente. Um interjogo entre o assumir e o adjudicar é estabelecido de forma a marcar as relações interpessoais em um grupo social, criando a coerência entre o grupo e os vínculos dentro dele. É na medida em que um adjudica e o outro recebe que se formam os vínculos.

Para sustentar suas afirmações, Pichon cria a "teoria dos três D" (depositante, depositário e depositado). Ao falar sobre o paciente e suas relações com o grupo familiar, Pichon diz que aquele adoeceu porque não conseguiu elaborar a alta carga de angústias e ansiedades que a família depositou nele. O paciente passa a ser o emergente das emoções e conflitos do grupo e traz à tona conteúdos emocionais que os outros membros do grupo não trazem. Nesta situação a família é o depositante, o paciente é o depositário e as angústias e ansiedades são o material depositado.

A teoria dos três $\mathrm{D}$ dá a base para o interjogo dialético de assunção e adjudicação de papéis, fundamental no desenvolvimento da teoria de grupos operativos:

Para que se estabeleça uma boa comunicação entre dois sujeitos, ambos devem assumir o papel que o outro lhe adjudica. Caso contrário, se um 
deles não assume o papel que o outro lhe adjudica, produz-se um malentendido entre ambos e dificulta-se a comunicação. Quando um dos dois (...) não assume o papel adjudicado (...) produz-se a indiferença e, nesse caso, a comunicação se interrompe. (PICHON-RIVIÈRE, 1995, p. 131)

Dentre os papéis surgidos na dinâmica grupal, Pichon destaca alguns por sua importância: o porta-voz, o líder, o bode-expiatório e o sabotador. Para alcançar a operatividade, os papéis não podem ser estereotipados, é preciso que eles sejam funcionais e rotativos.

O conceito de porta-voz é um dos pilares da teoria de Pichon. Ele é o membro que em determinado momento denuncia o acontecer grupal, o conteúdo latente do grupo que pode tratar de ansiedades, medos, necessidades, percepções e pensamentos da totalidade do grupo.

O porta-voz não fala só por si, mas por todos; o sujeito desempenha esse papel porque nele se dá uma articulação entre sua fantasia inconsciente e o acontecer do grupo em que se insere. O porta-voz atua como um radar e enuncia as angústias e necessidades que captou no grupo; e ele o faz porque essas angústias e necessidades estão relacionadas com sua história de vida.

Segundo Pichon, no porta-voz se conjugam dois níveis: o horizontal e o vertical. Por verticalidade entendemos aquilo que se refere à história pessoal do sujeito, permitindo-lhe a assunção de determinados papéis adjudicados pelos demais integrantes do grupo. Por horizontalidade entendemos aquilo que é o compartilhado pelo grupo, o denominador comum que o unifica. A horizontalidade não é a soma das verticalidades de seus membros, pois trata-se de uma construção coletiva que gera uma história própria do grupo e, conseqüentemente, uma identidade grupal. (PICHON-RIVIÈRE, 1994).

Quando o porta-voz enuncia algo, esses dois níveis estão articulados, pois o conteúdo enunciado é do grupo (horizontalidade) e ao mesmo tempo tem relação com a história pessoal do sujeito que assumiu o papel (verticalidade). O grupo deposita no porta-voz suas angústias e necessidades pela capacidade que o sujeito demonstra de suportar esse conteúdo. No entanto, exaurido também por suas próprias angústias, ele traz à tona os conteúdos emergentes, o que deve ser identificado e interpretado pelo coordenador do grupo visando uma intervenção que ajude o grupo a vencer as barreiras. Percebemos, assim, que o porta-voz tem grande importância, pois se torna depositário das ansiedades do grupo e veículo para sua emergência, sendo através de suas 
"denúncias" que o coordenador pode perceber o conteúdo latente do grupo e interpretálo.

Ainda, no processo de assunção e adjudicação de papéis, um sujeito pode se tornar depositário dos aspectos negativos do grupo ou da tarefa "num acordo tácito no qual tanto ele como os demais componentes do grupo estão comprometidos" (PICHONRIVIÈRE, 1994, p. 128). Nesta situação aparecem os mecanismos de segregação e o sujeito assume o papel de bode-expiatório.

Pelo mesmo processo, outro membro pode se tornar depositário de aspectos positivos do grupo, assumindo o papel de líder e atuando como facilitador na resolução da tarefa.

Já o papel de sabotador é assumido por aquele que representará a resistência à mudança. O sabotador aparece quando a ansiedade é muito grande, e em função disso outras necessidades são criadas e eleitas como mais importantes, com o intuito de fugir da tarefa e evitar a situação de mudança. Muitas vezes o discurso do sabotador pode ser favorável, mas na realidade ele faz da tarefa seu alvo de ataque.

Assim, a técnica operativa trata de mobilizar a estereotipia desses papéis e tornálos plásticos e móveis através da tarefa como consequiência da elaboração das ansiedades. Esses papéis devem ser tornar intercambiáveis para que o grupo se realimente e encare as tomadas de decisões.

\section{Momentos}

Para Pichon, o trabalho grupal abrange três momentos que se apresentam em uma sucessão evolutiva: a pré-tarefa, a tarefa ${ }^{3}$ e o projeto, "e sua aparição e interjogo constante podem situar-se diante de cada situação ou tarefa que envolva modificações no sujeito" (PICHON-RIVIÈRE, 1994, p. 19).

Esses momentos possuem características que em alguns momentos dificultam a tarefa e em outros a viabilizam. É importante que o coordenador consiga perceber tais características e interpretá-las para pensar em intervenções mais eficientes que ajudem o grupo a alcançar os objetivos.

O momento da pré-tarefa é caracterizado pela presença das técnicas defensivas que estão relacionadas à resistência à mudança (conseqüência do aparecimento das

\footnotetext{
${ }^{3}$ É importante destacar que ao longo do trabalho ora nos referimos à tarefa como o objetivo do grupo, o motivo pelo qual se reuniu, ora nos referimos ao momento do desenvolvimento grupal descrito por Pichon. Para diferenciar esses dois sentidos da palavra, sempre que "tarefa" se referir ao momento grupal, a palavra será escrita em itálico.
} 
ansiedades diante da situação de novidade). As ações presentes nesse momento se prestam a adiar a elaboração dos medos básicos que, "ao se intensificarem, operam como obstáculo epistemológico na leitura da realidade" (PICHON-RIVIÈRE, 1994, p.19).

Diante da impossibilidade de suportar frustrações de início e término de tarefas, o grupo inicia uma série de atividades para "passar o tempo" e passa a atuar "como se" estivesse executando a atividade objetiva. Assim, o grupo trabalha maneiras de não entrar na tarefa. Paradoxalmente, esse mecanismo criado diante de uma situação que o grupo não consegue suportar é também causador de uma frustração constante.

A pré-tarefa é um momento habitual do desenvolvimento grupal, sendo importante que o grupo a enfrente. No entanto, se houver um estancamento do acontecer grupal nesse momento, a produtividade será nula. O coordenador tem um papel fundamental para o vencimento desta etapa. Não se trata de evitar que o grupo passe pela pré-tarefa, mas sim de conduzi-lo "à análise sistemática dos fatores que impedem a penetração no segundo período, que é o da elaboração da tarefa" (PICHON-RIVIÈRE, 1994, p. 106).

O momento de tarefa é caracterizado pela abordagem e elaboração das ansiedades. As estruturas estereotipadas são rompidas e o grupo busca condições para a realização da tarefa objetiva. Dessa forma, o sujeito aparece com uma "percepção global" dos elementos em jogo e tem a possibilidade de elaborar estratégias e táticas para intervir nas situações e provocar mudanças. "Seria esquemático resumir, sob a noção de tarefa, tudo o que implica modificação em dupla direção (a partir do sujeito e para o sujeito), envolvendo assim a constituição de um vínculo" (PICHON-RIVIÈRE, 1994, p. 19, grifo nosso).

O momento do projeto se dá quando o grupo já aprendeu a superar as ansiedades básicas e se torna capaz de planejar ações e objetivos para o futuro. Na realidade, como todo mecanismo de criação, o projeto visa superar a "situação de morte", vivenciada quando percebem que com a realização da tarefa existe a possibilidade de separação ou finalização do grupo. Portanto, a projeção de novos objetivos futuros e de estratégias para alcançá-los está associada ao desejo de permanecerem juntos e constitui uma forma de lidar com os medos provocados pela possibilidade de separação.

Sendo assim, em seu caminho rumo à operatividade o grupo enfrentou ansiedades e as superou, realizou a tarefa objetiva e planejou objetivos e estratégias futuras. Ao longo desse processo, o grupo passa por transformações. As transformações 
sofridas e os novos objetivos colocados no projeto modificam a situação, que se tornará nova para o sujeito, dando novo início ao processo. Essa dinâmica é descrita por Pichon como o "modelo da espiral".

Portanto, quando atinge o projeto o grupo chega ao final de um ciclo e início de outro, já que irá se mobilizar para concretizar novas tarefas. Sendo assim, novamente ele passará pelos momentos de pré-tarefa, tarefa e um novo projeto, porém, a cada novo ciclo há um "aprofundamento", com saltos quantitativos de aprendizagem e também qualitativos no trabalho grupal.

Através desse processo, o grupo passa do implícito para o explícito, numa espiral dialética, representada num cone invertido, como mostra a figura 1. Isso significa que a cada novo ciclo a espiral se abre horizontalmente e cresce verticalmente, proporcionando saltos qualitativos associados a um acúmulo quantitativo em sua aprendizagem.

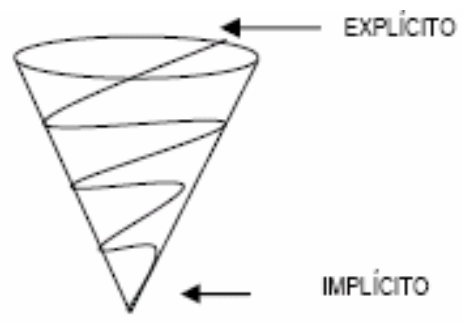

Figura 1: espiral dialética descrita por Pichon.

\section{VETORES DE AVALIAÇÃO DA DINÂMICA GRUPAL}

Todo grupo passa por momentos de estruturação, desestruturação e reestruturação ao longo de sua atividade conjunta. Diante disso, surge a necessidade de avaliar a operatividade do grupo, o que é complexo e subjetivo.

Pichon (1994), baseado em suas observações de fenômenos grupais, construiu uma escala de avaliação que é ponto de referência para a construção de interpretações. Fazem parte dessa escala sete vetores descritos a seguir:

Afiliação: trata-se do primeiro grau de identificação dos sujeitos com a tarefa e com os outros membros do grupo. O sujeito ainda guarda um certo distanciamento dos processos grupais, não se incluindo totalmente no grupo.

Pertença: com o desenvolvimento do grupo a afiliação vai se transformando em pertença. Desenvolve-se uma maior identificação e integração grupal, o que permite que se debrucem sobre a tarefa, elaborando uma estratégia, uma tática, uma técnica e uma 
logística. As distâncias são superadas e o grupo assume responsabilidade em relação ao desenvolvimento da tarefa.

Cooperação: é uma contribuição, ainda que silenciosa, para a tarefa grupal. A cooperação se estabelece sobre a contribuição de cada um para a tarefa de modo que haja um intercâmbio de papéis. O desenvolvimento de papéis deve ocorrer de forma complementar e intercambiável, permitindo a manifestação do caráter interdisciplinar do grupo e o interjogo entre a horizontalidade e a verticalidade.

Pertinência: é quando o grupo centra-se na tarefa. "Avalia-se a qualidade desta pertinência de acordo com o montante da pré-tarefa, da criatividade e da produtividade do grupo e suas aberturas para um projeto" (PICHON-RIVIÈRE, 1994, p. 125).

Comunicação: é um vetor fundamental de interação grupal, que pode ocorrer não apenas de forma verbal, mas também gestual. Neste vetor leva-se em conta, além do conteúdo da mensagem, a forma como ela é transmitida e para quem ela se dirige.

Aprendizagem: é dada pela soma das informações dos membros do grupo e ocorre de forma dialética, transformando quantidade em qualidade. A mudança qualitativa ocorrida no grupo implica em resolução de ansiedades, adaptação ativa à realidade, criatividade, projetos, etc.

Telê: é o clima estabelecido no grupo, trata-se de uma disposição positiva ou negativa para trabalhar com um membro do grupo.

O grupo, pela pertença, pela cooperação e fundamentalmente pela pertinência, na qual entram em jogo a comunicação, a aprendizagem e a telê, chega a uma totalização, no sentido de fazer-se em seu caminhar, em sua tarefa, em seu trabalhar-se como grupo. (PICHON-RIVIÈRE, 1994, p. 158)

\section{CONCLUindo}

Um grupo operativo é aquele que possui uma boa rede de comunicação, que se desenvolve eficazmente em sua tarefa e no qual cada membro assume um papel específico, mas com um grau de plasticidade que lhe permita assumir outros papéis funcionais. "Na assunção de papéis necessitados situacionalmente, configura-se um processo de aprendizagem da realidade, tarefa fundamental do grupo" (PICHONRIVIÈRE, 1994, p. 53).

A tarefa do grupo operativo está relacionada à mudança e à aprendizagem através da mobilização de estruturas estereotipadas, dificuldades de aprendizagem e comunicação provocadas pelas ansiedades surgidas no processo. 
Neste processo, é de fundamental importância o papel de porta-voz que, sendo o depositário das ansiedades do grupo, denuncia os problemas vividos por ele. Cabe ao coordenador decodificar a mensagem transmitida pelo porta-voz e pensar em estratégias para intervir no grupo em favor da sua operatividade. É o coordenador que favorece o vínculo entre o grupo e o campo de sua tarefa.

Encerramos este capítulo com as palavras de Pichon-Rivière (1994, p. 128):

Mencionamos o caráter interdisciplinar dos grupos. Isto nos permite reiterar um dos princípios básicos da técnica operativa: quanto maior a heterogeneidade dos membros - heterogeneidade adquirida através da diferenciação de papéis, na qual cada membro traz para o grupo toda a bagagem de suas experiências e conhecimentos - e quanto maior a homogeneidade em relação à tarefa - homogeneidade obtida pela somatória da informação, que adquire o ritmo de uma progressão geométrica, enriquecendo como parcialidade a cada um dos integrantes e, como totalidade, ao grupo - maior a produtividade que se obtém. 


\section{Capítulo 4}

\section{MONITORIA DISCENTE DE FÍSICA: UMA EXPERIÊNCIA DE SUCESSO}

Neste capítulo, contaremos a história do início do projeto de monitoria. Qual é o modelo dessa monitoria de Física? Quem o concebeu? Em que circunstâncias? Com que objetivos? Como esse projeto evoluiu até 2005, ano em que começamos a acompanhar o grupo de monitoria?

Responder a essas questões é importante para entendermos a gênese do processo. A monitoria não começou com um formato totalmente engessado, as circunstâncias em que foi concebida são especiais e merecem atenção, e o desenvolvimento do processo de criação e adaptação do projeto nos ajudará a entender o grupo de 2005 e também o do ano seguinte, 2006.

Partindo dos dados obtidos através da leitura do relato escrito pelo professor criador da monitoria e das conversas que tivemos, durante os anos de 2005 e 2006, acerca das condições de implantação desse projeto na escola, vamos reconstruir os eventos que marcaram o início dessa experiência inovadora.

\section{A GÊNESE}

O trabalho de monitoria discutido nesta dissertação aconteceu em uma escola confessional localizada em um bairro de classe média-alta da cidade de São Paulo.

Em 2002 o colégio passou por uma reestruturação em seu corpo docente. Nesse contexto Emanuel foi contratado para assumir as seis turmas de $1^{\circ}$ ano do Ensino Médio, ministrando a disciplina de Física. A reestruturação não dizia respeito apenas à troca do quadro docente, mas também a uma adequação às novas orientações dos PCNs. A escola passou a se preocupar em mudar o ensino tradicional que vinha praticando até então, marcado por aulas expositivas e exercícios de fixação, e a vislumbrar um trabalho que enfatizasse a importância da ciência, como se dá seu desenvolvimento e seu emprego tecnológico. Assim, para a disciplina de Física, decidiu-se adotar as apostilas do GREF (Grupo de Reelaboração do Ensino de Física) (1998), por se tratar de um material que tem como estratégia discutir os conceitos partindo do cotidiano do aluno e privilegiando as aplicações tecnológicas. 
Nessa escola existem dois tipos de reuniões pedagógicas para o ensino médio: por área e por série. Da reunião da Área de Ciências da Natureza, Matemática e suas Tecnologias participavam os professores de Física, Química, Biologia e Matemática, e dois assessores pedagógicos. Os objetivos dessas reuniões eram pensar conjuntamente estratégias interdisciplinares (dentro da mesma área ou com outras, no caso das reuniões por série), e apresentar os planejamentos trimestrais e anuais em busca de partilhar idéias.

O início das aulas trouxe uma série de desafios para Emanuel. Como todo início em uma nova escola, o professor dependia de adaptação a esses novos alunos, ao novo material e à nova perspectiva de aulas dessa escola. E, ainda, foi necessário lidar com a forte resistência dos alunos às atividades propostas.

Em meio a esse cenário, durante a reunião de área do final do primeiro trimestre, foi esboçado um modelo de monitoria discente, cuja motivação era a de "promover um maior envolvimento dos alunos com o estudo da Mecânica" (relato do professor). Em linhas gerais a proposta era a seguinte:

A proposta inicial consistia em criar a figura dos monitores em cada uma das seis turmas de $1^{\circ}$ ano, cuja função principal seria dar apoio às atividades pedagógicas da disciplina como aulas de laboratório, na orientação de atividades em classe, ajuda na resolução de listas de exercícios, montagem de grupos de estudos com os demais alunos e o que mais surgisse conforme as demandas de cada turma. Esta estratégia seria uma oportunidade de partilha de responsabilidades quanto à construção do conhecimento através de grupos de estudo, grupos de trabalho e encaminhamentos de dificuldades. Isto tudo além de um desejo de significativa ajuda durante as aulas, visto que os monitores, partilhando o mesmo universo cultural dos demais alunos de sua turma, estariam numa posição mais privilegiada para esclarecerem ou encaminharem alguma dúvida sobre os assuntos tratados nas aulas. (Emanuel)

Operacionalmente a monitoria funcionaria da seguinte forma: o professor indicaria dois alunos de cada turma para serem monitores de seus colegas. Esses primeiros doze monitores (pois havia seis turmas) atuariam durante um trimestre, sendo que ao final desse período outros dois monitores de cada turma seriam indicados pelo professor para substituí-los no trimestre seguinte. Essa dinâmica foi pensada para que a perspectiva de poder se tornar monitor estivesse presente entre os alunos durante todo o ano. E qual seria o critério de indicação do professor? A idéia era convidar os dois alunos de cada turma que tivessem as maiores médias em Física, uma vez que a função 
principal desses monitores seria a de ajudar os colegas com suas dificuldades na matéria.

Os assessores pedagógicos apoiaram a proposta da monitoria discente, apenas sugerindo que os monitores não fossem trocados ao final do trimestre, mas sim fossem somados. Dessa forma continuaria havendo mais de uma seleção de monitores durante o ano, porém os primeiros monitores continuariam atuando junto com os novos, ao invés de saírem e darem lugar a eles. O grupo então cresceria a cada nova seleção.

A quantidade total de monitores passou a ser uma preocupação que não se sabia como resolver, então foi decidido tentar e aprender na prática a administrar essa situação. Como forma de organização do trabalho decidiu-se por uma reunião semanal que contaria com a participação de todos os monitores e o professor, "na qual tudo o que ocorresse nas aulas de Física daquela semana, e mesmo fora delas, seria objeto de discussão, apontando acertos e ajustes necessários". (relato do professor, p. 50) Essas reuniões deveriam ocorrer fora do horário de aulas, com duração de aproximadamente uma hora, e a participação dos monitores em todas elas deveria ser o primeiro compromisso assumido por eles na monitoria.

Deveriam esses monitores receber algum tipo de pagamento por esse trabalho? Essa também era uma importante questão a ser resolvida. Decidiu-se por bonificá-los em suas médias trimestrais mediante avaliação de seus trabalhos como monitores; avaliação essa que seria feita pelo professor de modo bastante subjetivo.

E quanto às outras séries, os $2^{\circ}$ e $3^{\circ}$ anos? Afinal, Emanuel é professor de Física apenas do $1^{\circ}$ ano, sendo que outros dois professores ministravam aulas para o $2^{\circ}$ e $3^{\circ}$ anos. Como colocar a monitoria em prática inevitavelmente tomaria tempo dos professores, e sua implantação precisava ser imediata (afinal o primeiro trimestre já estava se encerrando), em meio a um clima de adaptação de professores e alunos às mudanças ocorridas na escola, os outros dois professores de Física se mostraram abertos ao projeto e ofereceram colaboração na sua implantação com os $1^{\circ}$ anos, mas não o aplicariam em suas séries.

Tendo todos esses pontos sido discutidos, o projeto foi levado à direção da escola que o apoiou prontamente. Sendo assim, estava tudo preparado para que uma nova experiência começasse a acontecer envolvendo alunos e professor da disciplina de Física do $1^{\circ}$ ano nessa escola. 


\section{2 - UM APRENDIZADO PARA O MODELO DE MONITORIA}

Esse foi o ano em que tudo começou, um ano de experimentações e de ajustes; ano de expectativas e de algumas desilusões, mas essencialmente foi o ano que forneceu um grande aprendizado sobre o funcionamento da monitoria.

Sem nos alongarmos muito com a experiência de 2002 vamos, em linhas gerais, pontuar o que de mais importante aconteceu neste ano e que forneceu bases de mudanças ou fortalecimento de atitudes para 2003. Como ao longo desse primeiro ano o professor coletava dados para o seu mestrado (através de questionários passados aos alunos e monitores, diário de campo produzido a partir das atas das reuniões de monitoria e gravações dessas reuniões), ele pôde estar atento a vários detalhes e, com isso, o projeto foi se modificando ao longo do tempo, em busca de maior eficiência.

A seleção foi feita exclusivamente pelo critério de desempenho nas avaliações, portanto, a escolha de quais alunos seriam convidados a se tornarem monitores partiu apenas do professor, sem que houvesse qualquer tipo de palpite ou influência das opiniões dos alunos.

Houve três seleções de monitores. Nas duas primeiras, foram selecionados dois monitores por turma e na última mais um. Lembrando que havia seis turmas de $1^{\circ}$ ano, ao final das três seleções a equipe contava com 30 monitores! A quantidade de monitores acarretou em problemas práticos para a coordenação do professor, para a distribuição de atividades (acabando por deixar alguns monitores "ociosos") e também para o atendimento às demandas de cada turma. Essa experiência mostrou que um número tão grande de monitores não torna a monitoria operacional, pelo contrário, acaba por gerar problemas que podem ser evitados ao se constituir uma equipe menor.

Foram três as principais atividades desenvolvidas durante essa edição da monitoria ${ }^{4}$. Uma delas era o Atendimento e Encaminhamento de Dúvidas dos Colegas de Classe. Essa atividade consistia basicamente na disponibilidade dos monitores para ajudar os colegas que precisassem deles. Eles deveriam atender os colegas com dificuldades a qualquer momento, podendo ser durante as aulas ou fora delas; o importante é que são os alunos que devem procurá-los e não o contrário.

Para melhor organização dessa atividade os monitores deviam preencher uma ficha de atendimento da monitoria que era entregue a eles pelo professor. Nessa ficha eles deviam colocar o nome do aluno atendido, a data, a dificuldade apresentada pelo

\footnotetext{
${ }^{4}$ Utilizaremos, em negrito, os mesmos nomes dados às atividades pelo professor Emanuel em seu relato.
} 
colega e assinalar se o problema foi resolvido por ele, se ficou pendente (necessitando de uma pequena pesquisa do monitor para responder posteriormente) ou se o professor devia assumir essa dúvida. Era necessário anotar os atendimentos durante toda uma semana e entregar ao professor na reunião de monitoria, ocasião em que receberiam uma nova ficha para os atendimentos da nova semana. Esses registros eram importantes para que o professor se familiarizasse com a natureza dos problemas apresentados pelos alunos, e pudesse verificar através de exercícios posteriores, se a dúvida foi mesmo sanada. Ao mesmo tempo, quando o monitor encaminhava uma dúvida ao professor, por não conseguir responder ele próprio, o professor podia procurar diretamente o aluno com dificuldade e conversar com ele.

Uma segunda responsabilidade dos monitores era o Controle das Inscrições para os Plantões de Física. Esses plantões ocorriam fora do horário das aulas e, com duração de uma hora, eram uma oportunidade a mais para que os alunos pudessem ter atendimento com relação a suas dúvidas com a disciplina. Nessa edição os plantões eram dados pelo professor junto com mais dois ou três monitores.

Os monitores eram responsáveis por registrar as inscrições dos alunos. Também para isso havia um formulário próprio que eles deveriam preencher, no qual constavam o nome dos alunos e o assunto que eles desejavam que fosse abordado. Além disso, os monitores deveriam, um dia antes do plantão, procurar os alunos para confirmar suas inscrições. Esse controle era importante, pois os plantões só podiam ocorrer caso houvesse alunos inscritos e, ainda, a indicação do assunto que os alunos gostariam de trabalhar permitia que o professor e os monitores se preparassem melhor.

E a terceira atividade dos monitores era o Apoio Pedagógico nos Plantões de Física. Embora o professor fosse o responsável por encaminhar o plantão, alguns monitores sempre o acompanhavam nessa tarefa. Como os alunos podiam indicar os assuntos que gostariam de trabalhar, o plantão era pensado para dar conta daqueles mais solicitados por eles, de forma que a questão que fosse mais apontada seria de responsabilidade do professor, e aos monitores caberiam atendimentos mais personalizados, de dúvidas mais pontuais.

Houve ainda situações em que os monitores encaminharam o plantão e o professor apenas supervisionou seu trabalho, sendo que essas situações foram todas muito bem sucedidas. E também em alguns momentos os monitores auxiliaram o professor no laboratório didático ou de informática, sendo devidamente preparados com antecedência. 
Essas eram as três principais atividades dos monitores. Ao final de cada trimestre eles eram avaliados pelo professor, de acordo com seu empenho nessas tarefas, para determinar quanto de bonificação em suas notas cada um receberia (embora, propositalmente, essa bonificação fizesse muito pouca diferença na média desses alunos).

Além dessa avaliação por parte do professor, houve também uma avaliação da monitoria feita pelos próprios monitores. Emanuel pediu que eles escrevessem um texto contando como foi a experiência. Pelos relatos, ela obteve muito sucesso, mas também apareceram muitas críticas e sugestões de mudanças. Tudo isso foi levado em conta pelo professor na edição seguinte da monitoria, em 2003.

\section{3 - A SEgunda Edição da Monitoria}

O relato da experiência da monitoria no ano de 2003 foi o que nos chamou a atenção para este projeto. Além disso, como veremos no capítulo seguinte, a turma que acompanhamos em 2005, no terceiro ano do Ensino Médio, era a mesma de 2003, quando estava no primeiro ano. Isto faz com que o relato dos eventos que marcaram esta segunda edição da monitoria seja duplamente importante para este trabalho: por um lado pontuaremos características importantes das bases do projeto de monitoria; por outro, os eventos narrados aqui serão importantes para entendermos os dados obtidos com o grupo de 2005.

A partir da experiência obtida em 2002 foi possível uma série de ajustes para 2003. Algumas mudanças significativas foram estabelecidas com relação à seleção dos monitores. Já em 2002, indiretamente, tinha sido possível verificar que o critério adotado para sua seleção - indicação do professor levando em consideração apenas os resultados nas avaliações de Física - não tinha sido a melhor opção. Em 2002, houve casos de monitores designados exclusivamente pelo professor que encontraram dificuldades de atuação, pois não foram reconhecidos por seus colegas de classe como alguém a quem eles poderiam procurar, ou que pudesse solucionar suas dúvidas. Já nessa época percebeu-se que, mais do que ter um bom desempenho na disciplina de Física, era importante que os monitores tivessem um bom trânsito entre os vários subgrupos de alunos que se formavam em suas turmas. Era necessário que esses monitores fossem reconhecidos como tais por seus colegas, que fossem pessoas de fácil 
acesso e de fácil comunicação, para que os alunos se sentissem seguros em procurá-los quando tivessem dúvidas com a matéria.

Sendo assim, para essa seleção de monitores, o professor, ao final do primeiro trimestre, pediu aos alunos de todas as turmas que respondessem a um questionário que contemplava suas visões e opiniões acerca da monitoria. Nesse mesmo questionário ele também pediu que cada aluno indicasse três colegas que ele gostaria que fosse seu monitor de Física (era possível que o aluno indicasse seu próprio nome se assim desejasse).

Tendo em vista a constatação de que era necessária a participação de todos os alunos no processo de escolha dos monitores que trabalhariam diretamente com eles, o pedido para que cada um indique três colegas se dá na crença de que ninguém melhor do que eles mesmos para dizer quem são as pessoas mais sociáveis e competentes para tal trabalho. Essas indicações acabam contemplando dois critérios de seleção: a sociabilidade (pois os alunos votam em colegas com quem eles têm uma boa relação) e, indiretamente, o de desempenho na disciplina (pois eles também sabem que para ajudálos com suas dúvidas os monitores devem ser "bons" em Física).

Ao analisar as respostas às várias perguntas desse questionário percebeu-se que a característica apontada como mais importante para um monitor foi a sociabilidade, corroborando o que já se tinha observado em 2002.

Então, os critérios adotados para a seleção de monitores de 2003 são:

1. Maiores médias trimestrais, desconsiderando os alunos cujas médias fossem menores que 7,5;

2. Maior quantidade de indicações dos colegas da turma, com limite mínimo de $1 / 3$ da quantidade de alunos na turma.

Em seguida, era preciso decidir quanto ao número de monitores, pois a experiência pregressa mostrava que 30 monitores era uma quantidade que gerava mais problemas que benefícios. Nesse ano, então, resolveu-se fazer duas seleções. Na primeira, em abril, seriam convidados dois alunos por turma e na segunda, em agosto, mais um aluno por turma seria chamado. Dessa forma, obteria-se uma equipe formada por 18 monitores (considerando as seis turmas de $1^{\circ}$ ano).

Com o número de monitores definidos e a lista de indicações associada ao desempenho dos indicados, o professor fez o convite a esses alunos. Caso algum deles não aceitasse (e isso aconteceu), seria então convidado o próximo da lista. 
Uma novidade importante apareceu em 2003. Alguns monitores do ano anterior gostariam muito de continuar participando do projeto, mas a mudança de série implicava em um novo professor que não havia aderido à monitoria. Assim, Emanuel abriu para que os alunos que estavam agora no segundo ano, e que haviam sido seus alunos no ano anterior, pudessem se inscrever para serem monitores inter-séries, ou seja, seriam monitores dos alunos do primeiro ano.

Seis alunos se inscreveram para a monitoria inter-séries e, somados aos 18 monitores do $1^{\circ}$ ano, compunham a equipe de monitoria que contou com um total de 24 monitores.

Marcou-se o dia da primeira reunião de monitoria: 05 de junho de 2003. Estar presente nessas reuniões era o primeiro compromisso que cada monitor assumia. Todos compareceram, inclusive os monitores inter-séries (alunos do $2^{\circ}$ ano que seriam monitores dos alunos de $1^{\circ}$ ), e as apresentações foram feitas. Nessa reunião inaugural, o professor explicitou melhor qual a função da monitoria, os compromisso dos monitores e a forma como seriam avaliados.

Nessa primeira reunião ficaram definidas as suas primeiras funções: os monitores do $1^{\circ}$ ano ficariam responsáveis pelo Atendimento às Dúvidas dos Colegas e Controle das Inscrições para o Plantão, enquanto que os monitores do $2^{\circ}$ ano ficariam responsáveis pelo Apoio Pedagógico nos Plantões de Física (nesse ano os plantões ficaram a cargo apenas desses monitores inter-séries).

[...] Chegou a reunião, que foi minha primeira ação como monitora. Recepção calorosa, bombons, boas vindas, foi só festa e tenho que admitir, fiquei bem mais segura...

Rossana

Ao convidar os alunos selecionados para a monitoria, o professor pediu para que cada um deles escrevesse um pequeno texto contando o que esperava ganhar e o que poderia oferecer na monitoria:

Sendo monitora de Física pretendo ajudar os colegas no que for possível, orientar o professor quanto às dúvidas da sala e a aceitação das aulas pelos alunos.

Gisele

Me tornando monitora espero ganhar conhecimento e facilidade com a matéria de Física, além de ajudar aos outros alunos a entenderem melhor a matéria. Também espero ajudar o professor a ver as dúvidas mais 
freqüentes da sala e descobrir os alunos com mais dificuldades, sempre com o intuito de ajudá-los.

Paula

Neste segundo trimestre, pelo que está dando para perceber, é preciso se esforçar e trabalhar bastante para entender a matéria e ter um bom desempenho, por isso eu acredito que ser monitora de física pode me ajudar bastante porque eu vou ter de me esforçar cada vez mais para, além de entender a matéria, conseguir passar meu aprendizado também para os meus colegas. Além disso, acho que sendo monitora de Física, eu posso passar os pensamentos dos meus colegas ao professor colaborando para aulas cada vez melhores. Espero conseguir cumprir com minhas obrigações para poder ser uma boa monitora e ajudar meus colegas.

Mônica

A partir do convite do professor para constituir um projeto inovador na escola em termos de estratégia pedagógica para a disciplina de Física, o grupo começa a se estabelecer para realizar a tarefa proposta, marcando o início do grupo. Quando aceitaram participar do projeto, cada um dos monitores e o professor organizaram, consciente e inconscientemente, representações de como seria realizar esse trabalho.

Podemos perceber pelo texto dos monitores que havia uma certa ansiedade em se preparar bem para a disciplina nesse primeiro ano de ensino médio. É recorrente em seus textos que eles esperam aprender mais e ter mais facilidade com essa disciplina, que costuma ser vista pelo corpo discente como o "terror" do Ensino Médio. Existe, portanto, um denominador comum a todos esses alunos-monitores: o interesse pelos estudos. Existe, anteriormente à constituição do grupo, um objeto de identificação entre os membros.

No final do ano também foi pedido aos monitores que escrevessem sobre como foi a experiência da monitoria. Um deles disse algo que nos remete a essa identificação:

[...] As reuniões de quinta-feira, além de ser um bom momento para você [professor] nos auxiliar, é também um bom momento para ver que no colégio existem também pessoas que pensam igual a você [ele mesmo], por isso eu até nomeei isso de N.A. (Nerds Anônimos)...

Felipe

No primeiro semestre os monitores não têm uma atuação muito grande, pois ainda estão se adaptando, mas grandes novidades para a monitoria aconteceram no segundo semestre. Como nossos dados para esse relato são apenas as passagens explicitadas por Emanuel, não temos a seqüência exata dos acontecimentos e nem detalhes de falas dos componentes do grupo. Apesar disso, podemos traçar uma linha 
condutora do que foi o trabalho da monitoria no segundo semestre através do relato dele sobre as atividades desenvolvidas nesse período, e de trechos da avaliação final dos monitores que se referem a esses momentos, bem como mensagens eletrônicas trocadas entre eles e trechos do diário de campo que estão contidos em seu relato.

Na primeira reunião do segundo semestre, Emanuel abriu para que os monitores expressassem suas impressões sobre o ritmo do curso (que ficou bem mais acelerado no segundo trimestre) e sobre o grau de exigência da prova realizada um pouco antes das férias de meio de ano. Os monitores falaram abertamente sobre o que pensavam a respeito desses dois assuntos, fizeram as reclamações que acharam pertinentes, mas também propuseram soluções para os problemas da sala de aula que estavam sendo manifestados naquela conversa. A transcrição do diário de campo de Emanuel, relativa a essa reunião, nos dá uma idéia da participação dos monitores:

Ruth e Stella: [...] Quanto ao ritmo das aulas elas nem acham que está puxado, mas que os seminários apresentados pelos alunos sobre as aulas do GREF estão com problemas, pois eu estou me intrometendo muito durante a fala dos alunos, estragando tudo o que os alunos prepararam. Eu argumentei que fiquei preocupado com os conteúdos trabalhados nos seminários e que tinha a intenção de dinamizar a aula e dialogar mais com os seminaristas.

Amanda: Ela levanta a proposta de eu dar a aula antes dos seminários dos alunos para que os alunos seminaristas não comprometam o conteúdo uma vez que fica muito difícil fazer perguntas para o grupo que está apresentando o seminário, pois isto os desconcentra e criaria intrigas posteriores. Eu falei que fiquei amarrado no esquema montado no início e que mudar agora poderia causar um desconforto com os que já apresentaram seus seminários, uma vez que eles são avaliados. Eu levantei a preocupação de que todos os alunos devessem ler as aulas previamente, o que diminuiriam muito as dúvidas durante os seminários. A Ruth então deu a idéia de que eu poderia sortear alguns alunos, durante o seminário, para responder a algumas questões sobre o texto da apostila, e dar alguma nota dependendo das respostas. Isto forçaria todos a se prepararem para os seminários, lendo previamente, uma vez que qualquer um poderia ser sorteado para responder a alguma questão [...]

Emanuel

Este fato acaba inaugurando uma nova atividade para os monitores: a Discussão

sobre Aspectos Ligados às Avaliações Aplicadas. Não temos meios de saber com certeza se assuntos dessa natureza nunca haviam sido tratados nas reuniões de monitoria antes, mas pelo relato do professor podemos perceber que foi a primeira vez que chamou a atenção de todos, dadas as opiniões relevantes e boas sugestões que os 
monitores deram para assuntos referentes às aulas ministradas e avaliações propostas pelo professor.

Estes e outros assuntos eram freqüentemente debatidos nas reuniões que cada vez mais assumia o caráter de co-responsabilidade para com o curso de Física, particularmente acerca dos desafios que surgiram durante o curso. [...] Este fórum de discussões sobre o andamento do curso é recorrente sempre que atividades novas surgem ou momentos avaliativos se afiguram. (Emanuel)

Aqui já podemos perceber um movimento de mudança de atitude desse grupo. Enquanto que no primeiro semestre os monitores faziam apenas o que era solicitado pelo professor, a partir deste momento os monitores começam a contribuir com sugestões no sentido de produzir resultados melhores dentro da situação problemática apresentada pelo professor.

Tal atividade - ajudar o professor com seu planejamento e re-planejamento do curso de Física - marcou bastante esse grupo de monitores. Verificaremos isso ao analisar o grupo de monitores de 2005, cujos integrantes já tinham sido monitores nessa edição de 2003.

Ainda no início do segundo semestre, o professor propôs mais uma atribuição aos monitores inter-séries: a Correção de Listas de Exercícios de Mecânica dos Primeiros Anos. A idéia consistia em passar a lista antecipadamente para os monitores resolverem (afinal eles haviam estudado essa matéria um ano atrás) e posteriormente discutir com eles os conceitos, as principais dificuldades e proposições de soluções. Feita a proposta aos monitores inter-séries, eles concordaram e demonstraram gostar da idéia, dizendo que essa seria mais uma oportunidade para revisarem a matéria aprendida no ano anterior.

$\mathrm{Na}$ realidade, Emanuel relata que essa atividade não foi implementada da maneira como ele a idealizara: acabou por não haver discussão das resoluções prévias. Mas mesmo assim ele diz que a experiência foi válida, pois as correções foram feitas baseadas no gabarito e os monitores disseram ter aproveitado a oportunidade para aprender mais.

Na mesma reunião em que a proposta de correção da lista de exercícios foi feita, monitores e professor também conversaram sobre a possibilidade de fazer um Plantão de Física Virtual. Essa idéia era de abrir salas de bate-papo na Internet para que os alunos pudessem, de suas casas, acessar as salas e serem atendidos pelos monitores escalados. Todos os monitores se empenharam muito na tentativa de viabilizar essa 
idéia: fizeram testes e propuseram idéias para resolver os problemas surgidos. Infelizmente, apesar do empenho de todos, chegaram à conclusão de que não seria possível viabilizar a proposta nesse momento devido às limitações impostas por esse ambiente.

Fazendo parte do conjunto das inovações surgidas no início do segundo semestre, encontra-se também a Tutoria de Monitores a Alunos com Dificuldades Específicas. A idéia para mais essa função dentro da monitoria surgiu em 2002, quando uma monitora decidiu, por conta própria, acompanhar mais de perto uma colega que tinha dificuldades. Tendo observado a atitude dessa monitora e os bons resultados conseguidos por ela, Emanuel pensou em utilizar os monitores em algumas situações, como quando um aluno novo chega à escola no decorrer do ano letivo, quando um aluno se afasta da escola por problemas de saúde, ou mesmo com alunos que têm alguma dificuldade específica.

Em 2003, a tutoria funcionou muito bem em dois casos. Um deles foi o de uma aluna que veio de outra escola e que estava apresentando grande dificuldade de adaptação. Um dos monitores de sua turma foi escalado para acompanhá-la, ajudando a menina a estudar os conteúdos de mecânica vistos no semestre anterior. O outro caso foi o de uma aluna que ficou afastada da escola por dois meses devido a um problema de saúde e, quando voltou, também apresentou dificuldade para acompanhar a turma. Mais uma vez um monitor foi escalado para auxiliá-la.

Os dois casos da tutoria foram muito bem sucedidos, inclusive com as duas meninas tutoradas relatando o quanto foi importante e útil ter o monitor por perto e interessado em ajudá-las nesses momentos.

Uma das primeiras atividades pensadas para o emprego dos monitores quando da constituição do projeto era a Ajuda durante as Aulas e em Atividades Orientadas. Porém, "este recurso foi pouco explorado e, quando foi, ficou a sensação de que poderia ser mais bem elaborado" (relato de Emanuel, p. 193).

Em seu relato, Emanuel destaca uma atividade experimental realizada durante as aulas de Física, na qual obteve apoio dos monitores, circulando e atendendo os grupos de alunos. Para tanto, Emanuel aplicou a atividade antecipadamente com os monitores (durante uma das reuniões), incluindo realizar o experimento, construir os gráficos e confeccionar os relatórios. Dessa forma os monitores estariam bem preparados para auxiliar os colegas. 
De modo geral essa atividade transcorreu muito bem, com o auxílio dos monitores sendo importante na dinâmica da aula, pois não sobrecarregava o professor no atendimento aos grupos de alunos. Mas, em alguns casos, principalmente de grupos que não eram próximos dos monitores ou não acreditavam em sua capacidade de auxiliá-los, os monitores não foram úteis e ainda foram destratados por alguns colegas.

Para esse tipo de atividade não temos informações de como o grupo se comportou. Temos apenas um relato sucinto das atividades, mas sem maiores explicitações sobre posturas dos componentes do grupo.

A grande novidade nesse ano foi a criação de Grupos de Estudos Coordenados pelos Monitores, se tornando a atividade de maior aproveitamento da monitoria nesse ano. Esses pequenos grupos, formados por no máximo quatro alunos com dificuldade, se encontravam uma vez por semana, na escola, fora do horário de aulas, em dia e hora previamente combinados, para estudarem juntos, com um monitor presente para auxiliar com as dúvidas.

Os monitores são integralmente responsáveis pelos seus grupos de estudos, controlando a freqüência de seus membros, canalizando atenções a este ou àquele assunto, deliberando sobre a possibilidade de acontecer ou não seu grupo de estudos naquela semana. (Emanuel)

Para controle e organização dos grupos de estudos os monitores deveriam anotar, no verso da ficha de atendimento da monitoria, quais alunos compareceram ao encontro do grupo e como estava o andamento dos estudos.

O envolvimento com essa atividade foi muito grande. Mas eles não se limitavam a apenas cumprir à risca a proposta feita pelo professor e apresentar os resultados. Sua participação ia muito além, opinando sobre os moldes e funcionamento dos grupos, sobre qual sua melhor estruturação e dando sugestões importantes para o desenvolvimento das atividades. Algumas mensagens eletrônicas enviadas ao professor sobre esse assunto evidenciam isso:

Acho q desse jeito q vc separou os grupos não vão ter grandes problemas, ainda mais $q$ são poucas pessoa, é mais fácil controlar, e se fizer alguma mudança, vai acabar juntando o pessoal q vai acabar conversando... Bjus

Oi Emanuel, Acho que você deveria mudar o grupo 3, a Marcela e o Plínio iriam se atrapalhar!!!! Você poderia trocar o Plínio pelo Gabriel. Isso é só, até breve. Stéfano

Stéfano 
Oi oi psor! Recebi a mensagem sobre o grupo de estudo e recebi também a proposta da Stella de trocar o Luiz Felipe com o Gabriel. Eu, sinceramente preferiria que os grupos permanecessem os mesmos, pois eu já combinei com o Luiz Felipe e o Thiago Marcos que eles serão meus "alunos" e nossos grupos de estudo serão às terças-feiras, após a aula de inglês. E acho que se eu ficar com este grupo, poderei atingir bons resultados. Um abraço e bom domingo, Ruth.

Ruth

Também há vários comentários espontâneos deles sobre esses grupos em seus textos de avaliação no final do ano:

[...] Mais recentemente foram atribuídas mais responsabilidades aos monitores, que ficaram encarregados de auxiliar um pequeno grupo de alunos com mais dificuldade em horários fora da aula, a entenderem a matéria e não mais na véspera da prova, o que para mim não trouxe prejuízo algum, pois trata-se só de uma hora por semana que, com certeza será muito válida para as pessoas do grupo, que às vezes só vão mal por falta de atenção nas aulas, e elas têm mais uma chance de tentarem melhorar $[\ldots]$

Paula

[...] De fato, o professor foi bem sutil. A princípio parecia que só teria que tirar dúvidas dos colegas. Realmente no início foi assim. Agora já é preciso vir [...] para auxiliar os alunos do grupo de estudos do qual sou responsável.

Thais

Como dito anteriormente, o segundo semestre foi marcado por grandes inovações para a monitoria. Os monitores passaram a opinar freqüentemente no planejamento do curso e passaram a atuar cada vez mais como co-pensores das estratégias pedagógicas, passaram a corrigir listas de exercícios, começaram a se responsabilizar por alunos específicos através da tutoria e ainda se tornaram coordenadores de grupos de estudos com os alunos com dificuldades. E todas essas novidades surgiram quase que ao mesmo tempo: nas primeiras semanas de agosto. Se no início parecia que eles teriam apenas que estar à disposição para responder dúvidas dos colegas e "aparecer" para as reuniões semanais, agora eles percebem que têm muitas responsabilidades e compromissos, não apenas com os alunos de suas turmas, mas também com o próprio grupo de monitoria.

É importante salientar a evolução do projeto de monitoria nesta segunda edição. Muito foi aprendido no ano anterior, com relação ao número de monitores, à forma de seleção, com os trabalhos realizados pelos monitores; e isso propiciou uma segunda edição mais desenvolvida. Novidades surgiram especialmente no que se refere às 
atividades dos monitores e à inserção da monitoria inter-séries. Justamente por não ter sido pensada pelo professor, e sim proposta pelos ex-monitores que gostariam de continuar a viver aquela experiência, temos na monitoria inter-séries uma importante medida do crescimento do projeto e do espaço que ela vinha conquistando dentro da instituição, entre os alunos que dela participavam.

\section{4 - O COROAMENTO DA MONITORIA INTER-SÉRIES}

Sobre a terceira edição da monitoria temos poucos dados. O relato do professor Emanuel foi escrito quando esta experiência ainda estava em curso, e como esta edição não era seu foco (mas sim a de 2003), não temos informações precisas sobre o grupo formado neste ano.

Em seu relato, Emanuel enfatiza o crescimento da experiência inter-séries em 2004. Como a inserção desta modalidade no ano anterior foi bem sucedida, ela continuaria a ser cultivada. A seleção, agora dos alunos dos $2^{\circ}$ e $3^{\circ}$ anos (tendo todos passado pela experiência da monitoria anteriormente), era feita com base em uma lista de interessados. Poucos se inscreviam e isso facilitava uma possível seleção.

Os monitores que estiveram com ele em 2002, e pediram para continuar na monitoria em 2003, permaneceram em 2004 sendo monitores dos alunos dos $1^{\circ}$ e $2^{\circ}$ anos. Essas seis monitoras foram apelidadas de "panteras", pois foram as pioneiras do projeto e encararam as "missões impossíveis", participando das três edições ininterruptamente. Se nos $1^{\circ}$ e $2^{\circ}$ anos ainda houve bonificação na nota para essas garotas, agora que cursavam o $3^{\circ}$ ano não receberiam qualquer nota em troca de seu trabalho como monitoras. Esse aspecto nos dá a idéia de que a participação no projeto era mais madura, não se fixando em recompensas burocráticas, como a nota, mas sim em ganhos que elas já tinham percebido que teriam: contínuo estudo (que era ainda mais valorizado pela proximidade do vestibular), participação nas reuniões (trocando informações e experiências com os outros monitores), e ainda a proximidade e o laço afetivo estabelecidos com o professor.

Os alunos do $2^{\circ}$ ano, que vivenciaram a monitoria pela primeira vez no ano anterior, também poderiam se inscrever para a monitoria inter-séries e vários deles o fizeram, querendo aprofundar a experiência. Neste caso, o interessante é que nem todos os inscritos haviam sido monitores antes, como Lucas e Nely, que participariam pela 
primeira vez. A bonificação na nota continuava a existir para esses monitores, a partir da comunicação entre Emanuel e a professora do $2^{\circ}$ ano.

Para completar a equipe, havia ainda os monitores intra-série, do $1^{\circ}$ ano, que seriam selecionados da mesma forma que no ano anterior, também recebendo bonificação em nota. Enquanto esses monitores seriam escolhidos apenas a partir do segundo trimestre, os monitores inter-séries já começavam a atuar desde o início do ano através dos plantões de Física, principalmente.

$\mathrm{Na}$ ocasião do relato de Emanuel, fazia parte do planejamento da monitoria daquele ano desenvolver atividades como: os plantões de Física, tutoria, correção de listas de exercícios, grupos de estudo; tudo desenvolvido através de escalas entre os monitores intra e inter-séries.

Contando com monitores das três séries do Ensino Médio, o projeto fica ainda mais enriquecido. Nas palavras de Emanuel:

\begin{abstract}
A contribuição que a monitoria inter-séries pode dar aos alunos dos $1^{\circ}$ anos vai além dos conteúdos. Dicas preciosas sobre o funcionamento e ritmo do curso, características do professor, caminhos que os alunos podem percorrer para conseguir um bom desempenho, fontes de informações extras além das trocas das vivências mútuas [...]
\end{abstract}

Os monitores inter-séries, ainda, podem ajudar os monitores intra-séries através da troca de experiências, contribuindo até mesmo para a diminuição do tempo de adaptação desses novos monitores.

Embora não tenhamos os dados completos dos eventos de 2004, percebemos que o projeto continuava a pleno vapor, marcado por inovações e pelo sucesso da monitoria inter-séries, que também ganhava espaço importante dentro do projeto.

\title{
Portanto...
}

Essas eram as informações que tínhamos sobre a monitoria no início de 2005 e que nos mobilizaram a acompanhar o desenvolvimento do grupo de monitores. $\mathrm{O}$ relato nos chamou atenção pelo desenvolvimento alcançado pelo grupo. Especialmente no ano de 2003, cujo relato é mais extenso, percebemos que o grupo vai além de simplesmente seguir as orientações do professor, pois os monitores se empenham em encontrar alternativas e resolver os problemas surgidos, sempre focados no melhor para a monitoria. 
Não podemos deixar de destacar o quão interessante e original era esse projeto. O professor conseguiu implicar alunos do Ensino Médio em seus estudos de Física e na disseminação desse conhecimento entre os alunos que sentiam mais dificuldade com esses conteúdos. Na realidade, o objetivo estava fortemente ligado ao estudo da Física, mas ia além: o professor queria proporcionar uma experiência que marcasse esses alunos; uma experiência que os transformasse, balizando suas decisões e suas atitudes no futuro, deixando de lado uma postura assistencialista de esperar do outro a resolução de seus problemas e se implicar em um processo de negociação social, procurando o que é melhor para si ao mesmo tempo em que contribui para o melhor para o outro.

Acreditávamos na possibilidade de uma mudança na mentalidade discente a partir de um esforço por fazer passar uma oportunidade de experiência. Experiência esta que pretensamente marcaria os sujeitos envolvidos de modo a inserir em seus universos culturais novos elementos que perturbariam uma ilusão estática construída há tempos, expresso num saber ostentado com orgulho e que os alienava, imobilizava e os fazia esperar do outro e no outro, toda e qualquer responsabilidade sobre seu próprio destino. (relato de Emanuel, p. 216)

Da parte dos monitores como experiência de vida, eu acho que alguma coisa guarda, alguma coisa fica, como toda experiência fica. (...) em alguma medida, as opções que eles vão fazer daqui para frente podem ser, de alguma maneira, balizadas, ou influenciadas por essa experiência que teve. É uma esperança minha, uma crença minha de que toda experiência que significa, que marca, te caracteriza. E te caracteriza no sentido de te dar direção para tua vida.

Emanuel (em entrevista no final de 2006)

(...) esses monitores galgam degraus de maturidade significativos quando se vêem capazes de negociar, de se comunicar e de superar limitações, dando o protótipo do perfil cidadão que imaginamos devesse pautar uma postura atuante, consciente e capaz. (relato de Emanuel, p. 221)

Mesmo que todo mundo está consciente de que aprende muito nessa operação, e além de aprender muito tem o aspecto da negociação verbalizada, então a proposta... a evolução das propostas da monitoria é cada vez mais o monitor prestar menos ajuda aos colegas, pra que eles vão encontrando esses níveis de autonomia cada vez mais acentuados.

Emanuel (em entrevista, meados de 2005)

Percebemos pelos trechos do relato e de entrevistas do professor, que sua preocupação era bastante abrangente. A monitoria proposta por ele proporcionava diversos ganhos: de aprendizagem de Física, de maior proximidade com alunos que o 
ajudavam a pensar seu curso, de desmobilização dos alunos de um discurso de falta de oportunidades, de vivência de uma experiência marcante.

Que os monitores aprenderam mais Física não há dúvidas. Eles relatam que por ter que ajudar os colegas são obrigados a estudar mais, e gostam disso. Se os alunos aprenderam mais Física não podemos dizer, mas existe a tranqüilidade de que mais uma ferramenta para auxiliar aqueles que se interessaram foi oferecida.

Com relação ao desenvolvimento grupal, a fundação foi dada pelo convite do professor para viver uma nova experiência. O grupo se constitui em torno da tarefa proposta por ele, mas avança. Toda novidade causa no sujeito uma ansiedade que tende a paralisar o trabalho objetivo: é quando o grupo se encontra na pré-tarefa. Entram em ação os medos básicos e o grupo precisa elaborar as ansiedades para avançar para uma nova fase na qual vencem a fragmentação do vínculo e centram-se em seu objetivo: a tarefa.

Percebemos pelo relato do professor que ao longo do ano os monitores cada vez mais se implicaram verdadeiramente com a monitoria. Eles eram criativos, propunham resoluções para os problemas enfrentados e criavam novos desafios para si mesmos (como as novas atividades, muitas vezes propostas pelos próprios monitores, ou aprimoradas por eles quando eram propostas pelo professor). Quando acompanhamos o grupo em 2005 (formado pelos mesmos monitores do grupo de 2003) percebemos, por conversas informais com os monitores e o professor, que a experiência vivida em 2003 foi muito marcante e muito profícua para todos eles, pois sempre falavam muito positivamente do trabalho realizado. O relato de Emanuel nos permite identificar a entrada no momento de tarefa, pois o grupo passa da inércia e da resistência à mudança para o movimento e a disposição às mudanças, sempre contribuindo para as inovações da monitoria.

A criatividade apresentada pelo grupo é marca da entrada em tarefa e, portanto, da operatividade do grupo. De acordo com Pichón-Rivière (1994, p.108):

$\mathrm{O}$ aspecto criativo do grupo não deve ser negligenciado como fator de avaliação, já que o consideramos como o índice mais significativo da operatividade do grupo. Esta acontece na medida em que se enfrentam novas tarefas com técnicas novas, tornando-se o grupo plástico (não estereotipado), coerente e operativo. Quando o grupo opera com um pensamento criador, adquire funcionalidade. Então, aparece como um fato objetivo que a tarefa em comum é de um rendimento superior. 
Ainda, o processo de evolução grupal se modifica e avança a cada ano através da inserção dos monitores inter-séries. O professor mesmo coloca como um dos ganhos desta modalidade da monitoria o fato de que os monitores experientes, trabalhando junto com os novos, dão dicas sobre o funcionamento do curso e da monitoria, contribuindo com sua experiência para acalmar as ansiedades e medos de que é acometido o novo grupo de monitores frente à novidade que enfrentam. Tal contribuição pode ter ajudado os novos grupos a vencerem a pré-tarefa mais rapidamente, partindo para um momento de concentração em sua tarefa objetiva, e fazendo com que o projeto de monitoria amadurecesse ainda mais a cada ano. 


\section{Capítulo 5}

\section{Um Novo Ano. Uma Nova SÉrie. Uma Nova MONITORIA?}

No capítulo anterior apresentamos a gênese da monitoria e o desenvolvimento das edições anteriores ao início de nossa pesquisa junto à monitoria de Emanuel. Neste capítulo, vamos tratar do grupo que acompanhamos sistematicamente durante o ano de 2005 por meio de filmagens das reuniões semanais, entrevistas com os monitores e o professor e diário de campo.

Conforme já mencionado, muitos dos integrantes do grupo de 2003 compuseram o grupo de 2005. Vamos então, nas seções seguintes, explicar o novo contexto da monitoria em 2005, o perfil dos alunos que compunham o grupo e as circunstâncias e expectativas que envolviam essa nova edição do projeto. Em seguida, apresentaremos os eventos que marcaram sua história e faremos uma análise do desenvolvimento deste grupo, dentro do projeto de monitoria que vinha acontecendo há quatro anos.

\section{O CONTEXTo}

Três edições muito bem sucedidas da monitoria já haviam ocorrido: 2002, 2003 e 2004. Em todas elas, Emanuel ministrava aulas para as seis turmas de $1^{\circ}$ ano do Ensino Médio. Em 2005 uma importante mudança aconteceu: diante de mais uma reestruturação do corpo docente de Física na escola, Emanuel passou a ser o professor do $3^{\circ}$ ano do Ensino Médio.

Houve certa apreensão com relação à monitoria, pois o $3^{\circ}$ ano é um tanto atípico, por ser o último ano da escola e é o momento em que os alunos começam a pensar na carreira profissional que querem seguir e se preparam para o vestibular. Portanto, este costuma ser um ano bastante atribulado para os alunos, pois se por um lado existe a euforia de que a escola secundária está acabando, por outro surge uma pressão de ter que estudar muito para serem aprovados no curso e na universidade que escolheram.

A maioria dos alunos faz cursinho pré-vestibular concomitantemente à escola. Normalmente eles freqüentam o colégio pela manhã e o cursinho à tarde, ficando com apenas o horário da noite livre para estudar. Isso preocupava o professor com relação ao futuro da monitoria: num ano tão conturbado, com tantas responsabilidades e 
compromissos, haveria alunos interessados em disponibilizar seu tempo para ajudar os colegas?

O professor, que já estava nessa escola há três anos, conhecia bem a cultura escolar estabelecida e nos relatou que havia ainda mais um agravante, motivo de preocupação: os alunos acreditam que no terceiro ano não há risco de reprovação, eles acreditam que mesmo que não atinjam a nota mínima, o conselho irá aprová-los, pois não se reprova em ano de vestibular! Assim, mais algumas perguntas surgiam para o professor: como os alunos encarariam a monitoria nesse ano? Eles realmente estariam interessados em se dedicar e procurar os monitores?

Para o professor também seria um ano diferente: novas estratégias pedagógicas, aulas de um novo conteúdo e a necessidade de montar todo o curso e as atividades que seriam desenvolvidas.

Um ponto que contava muito a favor era que a monitoria não seria novidade para esses alunos. As turmas de $3^{\circ}$ ano que teriam aulas com ele em 2005 eram as mesmas que estiveram com ele em 2003, quando cursavam o $1^{\circ}$ ano. Portanto, muitos desses alunos já haviam sido monitores antes e todos eles tiveram a oportunidade de freqüentar plantões e procurar os monitores quando necessário.

\section{A FormaÇÃo do GruPo}

Como o $3^{\circ}$ ano é cheio de peculiaridades, também era importante adaptar alguns procedimentos já estabelecidos da monitoria. Nos anos anteriores tinha-se chegado à conclusão de que um bom momento para fazer a seleção dos monitores era no final do primeiro trimestre. Porém, devido aos exames do vestibular, o terceiro ano acaba um pouco antes, no início de novembro e, por isso, seria interessante que os monitores pudessem começar a atuar mais cedo, ainda durante o primeiro trimestre.

A seleção foi feita nos mesmos moldes de 2003. Emanuel passou um questionário a todos os alunos de todas as turmas e pedia para que cada um indicasse três alunos que eles gostariam que fossem seus monitores (novamente, era possível uma auto-indicação). Com esse resultado em mãos, e considerando também as notas, Emanuel chegou aos nomes dos alunos que convidaria para a monitoria.

Nesse ano, o professor decidiu escolher dois monitores por turma em apenas uma seleção. Assim, haveria um total de doze monitores que atuariam, a princípio, na sua própria série. Como Emanuel tinha um bom diálogo com a professora que assumiu 
as turmas de $1^{\circ}$ ano, e como ela se mostrou muito interessada na monitoria, havia ainda a possibilidade de os monitores do $3^{\circ}$ ano trabalharem também junto aos alunos do $1^{\circ}$ ano.

A seleção foi feita no início do mês de abril, época em que o primeiro trimestre já se encaminhava para a sua etapa final. Como Emanuel já suspeitava, muitos alunos estavam profundamente implicados com seus estudos para o vestibular, alguns fazendo cursinho já desde o começo do ano e outros planejando começá-lo no segundo semestre. A conseqüência disso foi que muitos alunos recusaram o convite para participar da monitoria, alegando que não teriam tempo de se dedicar a essa atividade devido ao tempo que destinariam aos seus estudos para o vestibular. Em algumas turmas apenas um aluno aceitou ser monitor, fazendo com que a equipe fosse bastante reduzida se comparada à dos anos anteriores.

Emanuel decidiu iniciar as reuniões da monitoria com aqueles que haviam aceitado seu convite, mas não desistiu de conseguir mais alguns monitores; ele apenas adiou novos convites contando em pedir a ajuda dos que já haviam aceitado para convencer mais algum colega.

Como as turmas deste ano já haviam vivenciado a monitoria dois anos antes, não foi surpresa que a maioria dos indicados já tivesse atuado na monitoria anteriormente. Mas um fato interessante é que todos aqueles que aceitaram participar em 2005 já tinham participado de alguma das edições anteriores.

Novamente a reunião aconteceria semanalmente, em dia estabelecido de comum acordo entre os membros, com duração de aproximadamente 1 hora, e iniciaria após a última aula da manhã, às $12 \mathrm{~h} 30$.

A reunião inaugural foi marcada, porém nós não acompanhamos esse dia porque ainda estávamos buscando contato com Emanuel, sem saber que a monitoria já estava começando. Apenas estivemos presentes nas reuniões semanais a partir do segundo encontro. No início a equipe contava com oito monitores: Vanessa, Paula, Mônica, Tatiana, Lucas, Nely, Gisele e Silvio.

\section{OS EVENTOS}

Nesta seção, faremos a narrativa dos fatos que, em nossa visão, foram os principais eventos dentro das reuniões de monitoria ao longo de todo o ano. Enfatizaremos os trabalhos propostos, as atividades desenvolvidas pelos monitores e 
também as discussões que foram feitas dentro desse espaço. Como o ano foi cheio de acontecimentos, dividiremos os eventos em duas partes: aqueles que ocorreram no primeiro semestre (8 reuniões), e os que ocorreram no segundo semestre (10 reuniões). Essa divisão foi feita apenas com o intuito de facilitar a leitura, pois na prática não houve qualquer tipo de quebra ou ruptura das atividades na mudança de um semestre para o outro. Inclusive, muitas atividades começaram no primeiro semestre e tiveram continuidade no seguinte, como deixaremos claro. Embora tenhamos feito essa divisão, narraremos os eventos pautados pelas atividades desenvolvidas, e não necessariamente em ordem cronológica, reunião a reunião, mas deixaremos claro o tempo todo como os eventos estão ligados uns aos outros.

Neste ano, além de suas aulas na escola, Emanuel estava ministrando uma disciplina no ensino superior e também se encontrava envolvido com outros projetos profissionais. Todos esses compromissos acabaram por reduzir o tempo que ele tinha disponível para planejar as atividades da monitoria, o que culminou em um planejamento e uma sistematização das atividades da monitoria muito pequenos se comparados com o que ocorreu nos anos anteriores.

Durante o tempo de duração da reunião, vários assuntos são tratados. A idéia é que semanalmente sejam abordados os assuntos referentes àquela semana, como plantões, provas, dúvidas, andamento das aulas, dificuldades, entre outros. Portanto, o tempo da reunião era dividido entre a discussão de diversas atividades e acontecimentos relacionados à monitoria.

\section{$1^{\circ}$ semestre}

As primeiras quatro reuniões de monitoria foram realizadas com o intuito de se começar a organizar o trabalho que seria feito. Nesse início o grupo ainda não estava fechado e por esse motivo os monitores ainda não tinham sido formalmente apresentados às suas turmas.

No começo de suas atividades o grande desafio desse grupo era conseguir novos integrantes. Das seis turmas, apenas duas já tinham dois monitores e o grupo passou a discutir sobre nomes de alunos que eles acreditavam que poderiam ser bons monitores. Assim, o professor faria o convite a esses alunos, mesmo que eles não tivessem atendido os critérios de indicação dos colegas e/ou notas.

Essa não foi uma tarefa fácil e perpassou todo o primeiro semestre, fazendo parte das discussões de quase todas as reuniões. Professor e monitores levantavam 
possíveis nomes e discutiam sobre as condições de cada um, até chegar a um consenso. Quando um nome era aprovado, o professor procurava o aluno para fazer-lhe o convite, e o monitor também ficava responsável por procurá-lo e explicar como tudo funcionava e quais seriam suas atribuições. Esse esquema era bastante interessante porque, como os monitores eram muito próximos dos alunos, já sabiam de antemão aqueles que já tinham assumido compromissos com cursinho ou que teriam outras atividades que não permitiriam sua participação. Além disso, podiam dar informações ao professor que contribuíam para que ele pudesse pensar na melhor estratégia de abordar cada aluno para fazer o convite.

Dessa forma o grupo conseguiu mais dois integrantes: Marília e Ricardo. Os dois compareceram à quarta reunião do grupo apenas para conhecer a monitoria, sem compromisso de participarem, pois eles nunca haviam sido monitores. Ao final da reunião os dois demonstraram interesse e aceitaram integrar a equipe. Emanuel decidiu que, com a entrada deles, aquela era a hora de apresentar os monitores às suas turmas e inaugurar formalmente o início da monitoria perante os alunos.

As tentativas de conseguir mais monitores não pararam com a entrada de Marília e Ricardo, mas os outros alunos convidados por Emanuel não aceitaram a proposta. Muitos deles alegavam não ter tempo ou mesmo não ter jeito para ensinar a matéria. Assim, a equipe ficou definida em 10 monitores e o professor.

A partir da terceira reunião, Emanuel passou a trazer um pequeno lanche para os monitores. Em geral, ele trazia alguns pacotes de bolacha recheada e começava a distribuir entre eles já no início do encontro, de forma que todos podiam comer enquanto discutiam os assuntos daquele dia. Os monitores gostaram muito dessa idéia e inclusive cobravam quando Emanuel esquecia de distribuir o lanche logo no início da reunião. Embora pareça uma atitude simples, percebemos que esse foi um gesto bastante importante e muito valorizado pelos monitores. Essa atitude demonstrava que o professor se preocupava com eles, afinal estavam se encontrando no horário de almoço e todos já estavam com bastante fome.

Também na terceira reunião, Emanuel levantou uma discussão importante com os monitores: a bonificação na nota. Depois da experiência dos três anos anteriores e levando em conta que esses alunos já tinham tido a oportunidade de vivenciar a monitoria antes, a intenção de Emanuel dessa vez era a de não bonificá-los com qualquer valor de nota. Quando Emanuel perguntou se eles achavam que deveriam receber alguma bonificação, todos se manifestaram favoráveis a um ganho de nota na 
média, exceto Nely, que disse não estar preocupada com isso, mas sim em ajudar. Houve uma pequena discussão, com muitos falando ao mesmo tempo, mas o que predominou foi a idéia de que eles mereciam receber algo em troca do trabalho que estavam realizando. Dessa forma, ficou acertado que os monitores teriam suas médias sempre arredondadas para cima, com um máximo de ganho de 0,5 ponto.

Como dissemos, a monitoria para o terceiro ano só foi iniciada formalmente depois da entrada de Marília e Ricardo na quarta reunião, mas mesmo antes disso os monitores já vinham desenvolvendo uma importante atividade: a monitoria interséries, dando plantões para os alunos do $1^{\circ}$ ano. É importante destacar que nesse ano os monitores eram intra e inter-séries ao mesmo tempo, ou seja, o mesmo grupo de monitores auxiliava os seus colegas de classe do terceiro ano e também os alunos do primeiro ano (com a mudança de série do professor, todos os monitores faziam parte do terceiro ano).

Em função das experiências anteriores de sucesso com a monitoria inter-séries, Emanuel e a professora do primeiro ano, Caroline, decidiram investir nessa idéia. A professora participava do começo da reunião, comentando quais eram as necessidades de seus alunos, de que forma seria interessante que os monitores trabalhassem com eles e combinando datas para os plantões.

Embora possa parecer que não tivesse como dar errado visto que todos os envolvidos já tinham experiência anterior, as coisas não saíram como o esperado. De fato, os plantões para o primeiro ano chegaram a acontecer algumas vezes, mas aos poucos os monitores foram desistindo da proposta. Alguns desencontros ocorreram entre monitores e professores, por exemplo, com relação ao modo de resolução dos exercícios, pois Caroline havia ensinado a seus alunos um método de resolução diferente daquele que os monitores haviam aprendido com Emanuel no primeiro ano. A consequiência disso foi um desentendimento entre os monitores e alunos, desestimulando ambos os grupos a continuar investindo naquela modalidade - afinal, os monitores se sentiam perdidos, sem dar conta da demanda dos alunos e estes, por sua vez, sentiam que os monitores não poderiam ajudá-los de fato na aprendizagem do conteúdo.

No mês de junho, a professora compareceu a uma das reuniões pedindo que eles dessem plantão sobre velocidade angular para os seus alunos. Diferente da postura adotada normalmente pelos monitores, dessa vez eles disseram que não lembravam mais nada sobre isso e que não teriam tempo para estudar. Ninguém se mostrou disposto a 
investir mais nessa atividade. Mas em meio ao clima negativo que se estabeleceu, Nely se disse chateada e propôs então que, ao invés de ser um plantão, poderia ser um grupo de estudos, sob a coordenação dos monitores. Ninguém se interessou pela proposta e ela insistiu bastante com Lucas, que acabou aceitando. Assim, ficou acertado que os dois estudariam junto com os alunos do primeiro ano em um horário previamente marcado.

Depois desse episódio nunca mais se falou no assunto "monitoria inter-séries" em nenhuma reunião, nem mesmo para dizer que essa atividade deixaria de existir. A monitoria inter-séries simplesmente foi ignorada pelo grupo depois desse momento. $\mathrm{O}$ professor esclareceu o que houve com relação a esse assunto:

[...] a prof. Caroline, que esteve conosco no início do ano planejando estes plantões, parece que não conseguiu seduzir seus mancebos para terem aulas com os alunos dos 3 o anos, mesmo porque ela tinha os projetos dela e a escola não facilitava o entrosamento entre os professores. Deixo claro que não houve culpados, só descontinuação da proposta por desorganização e falta de empenho, tanto meu quanto da Caroline, pois havia outras demandas para darmos conta. Sendo assim, decidi não mais insistir em algo que gastava mais energia do que dava resultados, até porque os resultados não seriam necessariamente bem recebidos, caso desse algum problema neste processo (a escola não bancava os professores). Muito risco para pouco retorno. Pior para os alunos que perderam a oportunidade de viverem uma interessante experiência de trocas e ressignificação do conhecimento.

Após a apresentação dos monitores às suas respectivas turmas, marcando formalmente o início da monitoria para o terceiro ano, as principais atividades desenvolvidas seriam: o atendimento aos alunos com dificuldade a qualquer momento, o encaminhamento de plantões de dúvidas (que nesse ano aconteceriam, na maioria das vezes, sem a presença do professor) e o comparecimento às reuniões semanais.

Como comentamos anteriormente, Emanuel estava envolvido com outros projetos profissionais e já não dispunha de tanto tempo para o planejamento da monitoria como nos anos anteriores. Quando contamos a história de 2003, vimos que o professor havia instituído uma série de relatórios e fichas de atendimento que sistematizavam o trabalho dos monitores. Em 2005 nada disso aconteceu. Os monitores não precisavam preencher nenhum tipo de relatório a respeito dos atendimentos feitos durante a semana e nem sobre o andamento dos plantões.

No primeiro semestre foi possível observar algumas tentativas de organização do trabalho por parte do professor. Em uma das primeiras reuniões do ano, Emanuel 
chegou a anunciar que eles teriam que preparar um relatório da monitoria, mas isso nunca chegou a acontecer de fato. Os monitores apenas continuavam responsáveis pelas inscrições para os plantões, tendo que preencher a ficha com os alunos interessados e, mais tarde, tiveram que fazer relatórios sobre a tutoria (comentaremos sobre isso mais adiante).

Outra tentativa de organização feita pelo professor foi o pedido para que todos os monitores fizessem um resumo de alguns textos do livro didático. Com essa atitude ele pretendia que os monitores estudassem um pouco mais e, lendo o livro, fossem capazes de formular suas dúvidas antecipadamente, favorecendo seu trabalho como monitores. Porém, ao fazer essa proposta ele avisou que não leria esses resumos, o que causou bastante revolta entre os monitores, que não viam sentido em fazer algo que não seria lido. Emanuel insistiu na importância de eles fazerem isso, como forma de sistematizar seus próprios estudos e, embora aparentemente eles tivessem aceitado, o que se passou é que apenas uma monitora fez os resumos.

Além disso, ficou claro durante o decorrer das reuniões que não havia qualquer tipo de planejamento do que seria tratado em cada uma delas. Aparentemente Emanuel deixava os assuntos surgirem e tratava deles conforme a demanda, sem uma reflexão prévia de sua parte sobre quais eram as necessidades do grupo.

De fato, em conversa informal antes de uma das reuniões, o professor confessou que não havia planejado nada para aquele dia e que pretendia deixar as demandas dos monitores pautarem o encontro. Ele comentou também que andava muito atarefado e sem tempo de organizar atividades e programar uma pauta para as reuniões. Essa situação permaneceu durante todo o ano e, em nossa visão, é uma informação importante para entendermos a dinâmica dos encontros.

Das oito reuniões do primeiro semestre, em três delas foram discutidos assuntos relacionados à matéria que estava sendo aprendida. Curiosamente, nessas três situações os monitores reclamavam. Reclamavam que não estavam conseguindo resolver o exercício, reclamavam que estavam com dúvidas na matéria e reclamavam principalmente da quantidade de tarefas escolares que tinham para fazer. Esses assuntos surgiam naturalmente; eles estavam conversando sobre algo e de repente alguém manifestava uma dúvida, um problema, ou alguém comentava sobre um trabalho e as queixas eram retomadas. Em geral a atitude do professor era de ouvi-los, argumentar sobre a necessidade dos trabalhos escolares e solucionar suas dúvidas, chegando até mesmo a propor que os monitores resolvessem os exercícios da lista durante uma das 
reuniões. É importante ressaltar que Emanuel sempre ouvia atentamente a todas as reclamações deles e sempre procurava argumentar sobre os motivos que o levavam a agir de uma forma ou de outra como professor. Em conversas informais os monitores comentaram algumas vezes que admiravam Emanuel, pois ao contrário dos outros professores, ele dava oportunidades para eles expressarem suas opiniões.

Na quarta reunião do grupo, quando Marília e Ricardo passaram a integrar a equipe, Emanuel apresentou as principais atividades que ele estava pensando em desenvolver naquele ano. Uma delas seria com relação à recuperação. Nesse ano não havia nenhum plano de vincular a recuperação paralela diretamente à monitoria, mas apenas instruir os monitores a estarem atentos aos alunos e ajudá-los em suas atividades.

Outra atribuição dos monitores seria corrigir as listas de exercícios. Embora tivessem aceitado essa atribuição nesse momento, o que se observou no decorrer do ano foi uma série de reclamações quando o professor pedia que eles corrigissem alguma lista. Inclusive, durante a entrevista do final do ano, alguns deles falaram negativamente sobre essa atribuição.

Ah,[corrigir as listas] é chato, é mais um trabalho pra casa né, parar e ficar lendo tudo. Aí tem coisa que você não tem certeza, não sabe se tá certo ou se não tá. [silêncio] Não sei, eu achei chato.

Ricardo

Como vimos no capítulo anterior, uma atividade de muito sucesso dentro da monitoria em 2003 foi o oferecimento de grupos de estudo coordenados por um monitor. Portanto, em 2005 Emanuel voltou a propor que esses grupos fossem organizados, inclusive colocando algumas novidades: os grupos não precisariam apenas estudar a matéria que estava sendo vista em sala, mas também poderiam ser organizados para estudar matérias dos anos anteriores, visando à preparação para o vestibular.

A grande surpresa foi que desde o primeiro momento os monitores foram contra a idéia dos grupos de estudo. Eles argumentavam que não haveria público e ainda que eles mesmos já dariam os plantões e não teriam tempo para se envolver também com os grupos de estudo. Todas as vezes que Emanuel tocou nesse assunto, os monitores rejeitaram a idéia, a ponto de ela ser abandonada. Quando perguntamos a ele o que houve com relação a essa atividade, ele nos respondeu o seguinte:

Tentamos formar grupos de estudos no começo dos trabalhos, mas vimos que a realidade dos 3 o anos era muito específica e diferente dos lo anos. $O$ contexto do lo ano era de adaptação à novidade de saída do ensino 
fundamental para o médio, o que facilitava muito a inserção da monitoria como novidade, assim como todos os projetos que dela advinham, como os próprios grupos de estudos. [...] Nos 30 anos a lógica (neste colégio) segundo minha interpretação, é de expectativa de finalização de uma experiência de tormentos e desgostos, no que diz respeito à média do senso comum discente referente às suas relações com o saber escolar. Nem a oferta dos grupos de estudos vingava, pois surgia a alegação de que os alunos faziam cursinho à tarde, tinham outras atividades e que, não tendo despertado o hábito de estudar fora das aulas regularmente durante todo seu ensino médio, não seria no 3 o ano que isto se tornaria viável.

Embora os argumentos do professor sejam bastante consistentes com relação à diferença de realidade vivida pelos alunos no $1^{\circ}$ ano e no $3^{\circ}$ ano, ainda assim é interessante a postura dos monitores, pois apesar do sucesso da experiência vivida em 2003, eles não quiseram nem ao menos tentar investir nos grupos de estudo novamente em 2005. Isso nos remete à cultura escolar estabelecida nesta escola. Por diversas vezes o professor nos relatou sua preocupação com relação a isso, pois os alunos não pareciam ter qualquer comprometimento com o conhecimento. $\mathrm{Na}$ opinião dele, o que eles queriam era apenas cumprir suas tarefas burocraticamente, para vencer essa etapa escolar de suas vidas o mais rapidamente possível.

Com a não realização dos grupos de estudo, Emanuel decidiu apostar em outra atividade da monitoria: a tutoria. Nesse ano a tutoria parecia ser o grande investimento do professor. Em 2003 ela já tinha figurado como uma das atividades realizadas, mas em 2005 ela parecia adquirir um ar de novidade e de esperança.

Na quarta reunião Emanuel colocou a proposta para os monitores, mas em tom de sondagem e de algo que ainda seria melhor pensado antes de ser colocado em prática. No encontro seguinte, o professor propôs a tutoria de forma mais estruturada. Ele disse que a idéia era que cada monitor ficasse responsável por um ou dois alunos de sua classe que estavam com notas baixas, e ele teria que procurar seus tutorados diariamente para perguntar se eles estavam com alguma dúvida, checar se eles estavam fazendo as tarefas e se tinham problemas com elas. Assim, foi feita a distribuição de tutorados por tutor para que os trabalhos se iniciassem. Como forma de organização desse trabalho, os monitores deveriam entregar semanalmente um relatório sobre seu tutorado. Mesmo que nada de novo tivesse acontecido naquela semana, o relatório deveria ser entregue constando que o aluno não teve nenhuma dúvida ou problema.

Comentamos anteriormente o fato de que os monitores não precisavam entregar qualquer tipo de ficha de acompanhamento ou relatório a respeito da monitoria. De fato, 
com a instituição da tutoria, essa passou a ser a única atividade da qual era exigida essa tarefa burocrática. E havia uma real cobrança do professor com relação à entrega desses relatórios.

No início da tutoria, parecia realmente que ela se constituiria no grande ganho da monitoria nesta edição. Quando da entrega dos relatórios nas reuniões, os monitores também relatavam oralmente o que estava acontecendo com seus tutorados e aproveitavam esse momento para trocar informações com o professor, que por sua vez também os instruía com relação à melhor maneira de tratar com esses alunos.

É importante ressaltar que todas as discussões que ocorreram tinham um caráter muito interessante: na maioria das vezes as conversas não eram compartilhadas por todos, elas costumavam ser polarizadas entre o professor e um dos monitores. Quando falamos em um grupo de monitores discutindo todos esses assuntos, a imagem mais provável que nos vem à cabeça é a de que todos participam ativamente, colaborando com opiniões e debatendo idéias; por isso é importante deixarmos claro que não era exatamente dessa forma que os encontros se desenrolavam. Por exemplo, quando comentamos que os monitores relatavam nas reuniões quais eram os problemas enfrentados pelos seus tutorados, em geral o professor perguntava a um monitor por vez sobre o andamento de sua tutoria, sem que os outros monitores interferissem na conversa, nem mesmo para dar sugestões caso o monitor estivesse relatando algum problema.

Parece que a forma de interação que predominava nesse grupo era a "dual”, em que cada monitor falava com o professor, mas com a presença do outro marcando a modalidade de comunicação com ele. Embora as conversas em geral fossem polarizadas, eles estavam em grupo, e estavam dispostos a manter esse tipo de interação com o professor em um espaço conjunto.

As atividades dos monitores que relatamos até agora se referiam ao contato direto deles com os outros alunos, mas havia outra atividade que se constituiu em algo muito forte e muito presente, que realmente instigava a participação deles e com a qual eles se envolviam com muito afinco: ajudar o professor.

Já desde o início dos encontros o professor pediu ajuda aos monitores para o trabalho trimestral, que compunha a média de Física de maneira significativa. A monitoria acabava por proporcionar um ambiente em que o professor tinha alguns alunos muito próximos, que poderiam contribuir com seu planejamento de aulas na medida em que conheciam muito bem a realidade de todos. Portanto, ele sempre pedia a 
opinião dos monitores com relação à possível adesão dos demais, prazos, ou mesmo pedindo que eles pensassem em algum trabalho que seria interessante para todos.

Da mesma forma, Emanuel também costumava perguntar aos monitores como os alunos receberam o trabalho proposto, se houve reclamações e de que tipo, se eles estavam fazendo ou não as tarefas. Essa fonte de informações era valiosa para o professor, pois ele poderia a qualquer momento replanejar estratégias que não estivessem funcionando bem.

Uma situação, ocorrida na última reunião do primeiro trimestre, foi bastante marcante. Nessa ocasião, Emanuel precisava montar uma atividade para o trabalho do segundo trimestre. Ele tinha uma idéia ainda muito vaga, pretendia utilizar uma coleção de revistas que estavam nas bancas na época, chamada "Gênios da Ciência", mas ainda não sabia como poderia fazer uso delas. Ele resolveu colocar o assunto em pauta na reunião de monitoria, pedindo que os monitores pensassem em possíveis atividades, usando aquelas revistas ou não, para que eles debatessem sobre as possibilidades. O que foi atípico é que, embora a discussão tenha começado sem muito empenho dos monitores, o problema acabou por capturar a todos de forma que o assunto foi debatido durante toda a reunião. Os monitores deram muitas idéias, algumas inclusive pouco aplicáveis, e o encontro foi encerrado sem que uma solução fosse encontrada. Esse episódio foi citado espontaneamente por alguns monitores durante a entrevista final, e outros comentaram sobre ele quando perguntados, sempre afirmando que essa foi uma importante função deles como monitores: ajudar o professor a resolver os problemas da disciplina.

Pesquisadora: E como que você se sentiu em ajudar o Emanuel a resolver esse tipo de problema, do trabalho trimestral?

Paula: Então, é bom porque às vezes chega final de semestre tá super carregado, cheio de coisa pra fazer, todo mundo tinha prova no final do trimestre, trabalho, então ele vê como que tá, se a gente tem como fazer ou não. Se é alguma coisa viável ou não. Então é bom você ter a visão de quem tá do outro lado.

$[\ldots]$

Paula: [quando o professor pede ajuda aos monitores] você tem uma amostra do que é legal e ainda pegando um pessoal que é interessado, que vai bem, que tá falando com consciência... 
Outro aspecto interessante é que o professor acabou optando por um tipo de trabalho que nada tinha a ver com qualquer das sugestões dos monitores. Quando perguntados sobre como se sentiram a esse respeito, os monitores defenderam sua contribuição dizendo que, embora o professor não tenha utilizado exatamente as idéias que eles deram, com certeza tudo o que foi dito lá foi importante para que ele elaborasse o trabalho da maneira como foi proposto.

Ah... eu acho que ele ouviu a gente sim. A gente deu a idéia e dentro das idéias tinham alguns aspectos que acho que ele levou em consideração. [...] Eu acho que mesmo ele não levando em consideração a idéia mesmo em si, ele levou o que tava dentro da idéia. Sei lá, eu acho até legal, que é uma idéia que não surgiu na hora, mas que eu acho que aquela opinião ajudou as idéias.

Marília

As reuniões eram essencialmente marcadas por momentos em que se discutiam todos os assuntos relacionados com a monitoria, mas estavam longe de ser um ambiente "profissional". Havia muito espaço para conversas diversas, sobre os desafios de fazer auto-escola, os problemas com os pais, angústias geradas pelo último ano escolar e principalmente sobre o vestibular. Essas conversas proporcionavam a esse grupo de alunos uma oportunidade de compartilhar dúvidas, angústias, alegrias, e conferiam ao espaço da reunião de monitoria um ar de "encontro de amigos". Encontro agradável, no qual se falava de trabalho sim, mas não apenas disso, era possível conversar sobre qualquer assunto.

Na reunião? Ah! Eu acho legal porque é uma coisa descontraída, parece às vezes que nem é, tipo, professor e aluno, aquela coisa, às vezes é tipo amigo, parece amigo que está conversando... então a gente conversa de tudo que precisa conversar, mas de uma maneira descontraída. Por isso que eu acho que, às vezes, se fosse uma coisa por obrigação que nem eram as outras monitorias, seria diferente, tipo... eu não falaria tanto. [...] Tem sim a obrigação de estar lá e conversar sobre tais assuntos, mas dentro desses assuntos a gente pode viajar. É, eu acho legal assim.

Marília

É muito interessante perceber que quando as discussões estavam relacionadas a ajudar o professor em seu trabalho ou mesmo quando conversavam sobre assuntos não relacionados diretamente com a monitoria, como a futura carreira ou suas angústias pessoais, a modalidade de interação dual se dissolvia e eles mantinham diálogos também uns com os outros, colaborando para resolver o problema do professor ou dando opinião sobre o que algum colega falava. 
As discussões que instigavam mais colaboração dos monitores eram as que envolviam alguma forma de ajuda ao professor. Quando discutiam os trabalhos trimestrais, ou assuntos relacionados ao trabalho do professor em sala de aula, os monitores costumavam conversar também entre si e não apenas com ele.

O primeiro semestre se encerrou com o encontro em que eles discutiram, durante todo o tempo, sobre qual poderia ser o trabalho trimestral que o professor proporia à turma. Quando chegou o horário do fim da reunião, Emanuel decidiu parar a discussão mesmo sem uma solução. Em seguida, monitores e professor fizeram uma pequena festa de encerramento das atividades do semestre. Cada um levou um prato de comida ou bebida e o momento foi de confraternização e descontração.

\section{$2^{\circ}$ semestre}

Logo na primeira semana de agosto, as reuniões de monitoria foram retomadas. Todos os monitores estavam de volta exceto Silvio, que abandonou o grupo devido a novos compromissos assumidos por ele em função da proximidade do vestibular.

Neste reinício dos trabalhos, Emanuel já tinha uma importante função para delegar aos monitores: ajudar os alunos novos na escola.

No segundo semestre, algumas turmas receberam novos alunos, alguns transferidos de outras escolas, outros chegando de intercâmbio no exterior. $\mathrm{O}$ fato é que era preciso checar qual a matéria que esses alunos estavam aprendendo em suas escolas anteriores, e verificar se eles conseguiriam acompanhar a disciplina normalmente ou se precisariam de ajuda devido a diferenças curriculares entre as escolas.

Os monitores foram incumbidos de procurar os alunos novos de suas turmas e perguntar o que eles já haviam aprendido em Física, apresentar as apostilas (do GREF) que Emanuel utilizava com os alunos, apontar a matéria que já tinha sido desenvolvida durante o primeiro semestre e as listas de exercícios que eles já haviam feito.

Esse foi apenas o primeiro passo, pois uma vez constatado que alguns deles não haviam estudado a mesma matéria que Emanuel ministrara, algo deveria ser feito para ajudar esses alunos. Para decidir o que fazer, o professor pediu sugestões aos monitores. Nely e Lucas se envolveram bastante nesta discussão propondo que os monitores procurassem esses alunos e pedissem para eles lerem a apostila. Emanuel gostou da idéia e completou que eles deveriam acompanhar se esses alunos estavam lendo e até mesmo colocar um prazo para que eles lessem tudo. Os outros monitores presentes não opinaram a respeito desse assunto e prevaleceram as idéias dadas por Nely e Lucas, 
completadas pelo professor. Na reunião seguinte, Emanuel perguntou aos monitores se eles já haviam conversado com os alunos novos, recebendo uma resposta positiva de quase todos eles.

A ajuda com o trabalho trimestral continuou ativa no segundo semestre. Logo na primeira reunião após as férias, Emanuel já se referiu ao trabalho perguntando o que os monitores acharam, pois naquela semana ele tinha anunciado em sala de aula que o trabalho seria montar um programa de rádio que abordasse algum conteúdo de Física (lembrando que isso não tinha nada a ver com as sugestões dadas pelos monitores). Eles disseram que gostaram muito, mas tinham muito pouco tempo para fazer tanta coisa. $\mathrm{O}$ trabalho teria um caráter interdisciplinar e, além de constituir a nota trimestral, seria também aproveitado para a mostra cultural que acontece na escola todos os anos. $\mathrm{O}$ programa de rádio deveria dar conta de várias disciplinas, como Física, Química, Biologia e Português, mas apenas a parte referente à Física contaria para a nota trimestral dessa disciplina.

Emanuel explicou em detalhes como o trabalho seria feito e houve um predomínio de sua fala. Mas os monitores mostraram a ele que existia um problema: o trabalho completo só ficaria pronto para o terceiro trimestre, então o que o professor poderia avaliar para dar a nota referente ao terceiro trimestre que já estava muito próximo de acabar?

Alguns monitores deram sugestões do que ele poderia fazer e Emanuel ouviu atentamente, mas acabou acatando a sugestão de Nely, sobre fazer um piloto do programa. Durante toda a discussão sobre detalhes do trabalho, apenas Nely, Mônica e Lucas participaram, sendo que os outros monitores apenas ouviram, sem manifestar qualquer opinião. Por isso, quando resolveu aceitar a sugestão de Nely, Emanuel fez questão de perguntar aos outros monitores o que eles acharam da idéia e todos concordaram.

Durante as semanas seguintes, Emanuel percebeu que uma grande confusão estava sendo gerada a respeito desse trabalho porque ele era constituído de várias partes, cada uma referente a uma disciplina, e os alunos estavam confundindo as instruções dadas por cada professor. Por isso, ele resolveu perguntar aos monitores se a parte referente à Física estava clara. Realmente havia uma grande confusão até mesmo entre os monitores; Emanuel esclareceu exatamente o que eles deveriam fazer com relação à disciplina de Física e pediu a ajuda deles para deixar isso claro aos outros alunos também. Ele queria que todos os grupos fizessem um resumo das pesquisas e gravassem 
uma fita sonora, uma espécie de programa de rádio piloto, como trabalho do terceiro trimestre. Os monitores aproveitaram o momento para reclamar que o tempo era muito pequeno para fazer tudo o que Emanuel estava pedindo. Então o professor pediu sugestões sobre o que fazer a esse respeito. Nely, Lucas e Mônica novamente foram os monitores que se envolveram nessa discussão, debatendo sobre possibilidades, enquanto os outros apenas escutavam as conversas. As discussões entre eles ficaram intensas, até que Nely sugeriu ao professor que ele usasse dois dias letivos para gravar o trabalho piloto, pois o maior problema apontado era tempo para que os grupos se reunissem fora da escola. Emanuel gostou muito dessa sugestão, mas ninguém estava prestando atenção quando Nely falou, então ele chamou a atenção de todos os monitores e completou a idéia dela, encerrando o assunto com uma solução que satisfazia a todos.

$\mathrm{Na}$ reunião seguinte, o professor comentou que a sugestão de Nely foi boa porque acalmou os alunos. Com isso, eles conversaram mais uma vez sobre a confusão gerada pelas informações diferentes que cada professor dava, e Emanuel comentou com eles qual seria seu planejamento para conciliar as aulas com o trabalho.

Outra atividade que teve continuidade foi a tutoria. Na primeira reunião do segundo semestre Emanuel avisou aos monitores que na semana seguinte essa atividade deveria recomeçar. Imediatamente começaram as reclamações! Os monitores reclamavam que a tutoria não funcionava, que eles tinham que ficar "no pé" dos alunos que só dormiam durante toda a aula, não faziam as tarefas e nem se empenhavam para melhorar sua aprendizagem. O professor ouviu todas as reclamações com muita atenção e respondeu uma a uma, enfatizando que esse trabalho era importante e que deveria continuar. Embora desse atenção às reclamações dos monitores, o professor permaneceu firme com relação à manutenção dessa estratégia. Sempre que as reclamações surgiam, ele argumentava sobre a importância da tutoria e dava sugestões sobre como os monitores poderiam lidar com as situações que os incomodavam. Se o tutorado não fazia nada, não havia problema algum para o monitor, bastava que ele escrevesse isso detalhadamente no relatório da tutoria.

Durante o resto do semestre não se falou mais na tutoria dentro das reuniões. Esse fato é bastante interessante, visto que era um trabalho permanente dos monitores e uma grande aposta do professor. Em entrevista no final do ano, quase todos os monitores reclamaram da tutoria e a citaram como um ponto negativo daquele ano. Eles alegavam que era muito desconfortável ter que procurar os tutorados todos os dias e cobrar que eles estudassem, principalmente porque eles não viam qualquer esforço 
desses alunos para se recuperarem. Para eles, os alunos deveriam procurá-los caso quisessem ajuda, pois de nada adiantaria eles ficarem cobrando quem não queria ser ajudado.

A única coisa que eu acho que não deu muito certo... não é que foi ruim... mas que não deu muito certo, foi aquilo de a gente ficar na responsabilidade de uma pessoa só. [...] a partir do momento que vira obrigação ter uma monitora para aquela pessoa ela se sente obrigada a me dar... sei lá... as atitudes dela me mostram que ela quer mostrar que está indo bem... então sei lá.... acho que isso pressiona muito a pessoa, quer dizer que se fosse uma coisa mais solta ela seria mais fácil de... de entender as coisas e de perguntar.

Marília

Ah, a tutoria, acho que não deu tão certo... porque pelo menos comigo eu não ia correr sempre atrás, porque eu acho muito chato. A pessoa não vai querer fazer, não ta interessada, não adianta nada forçar. Eu acho que não dá certo você mandar um aluno ficar correndo atrás do outro.

Paula

Neste segundo semestre parece que a disponibilidade dos monitores para darem plantões também diminuiu bastante. Quase todas as vezes que Emanuel pediu candidatos para o plantão da semana não obteve resposta positiva de ninguém. Eles sempre alegavam que tinham outras provas para estudar, ou que não estavam entendendo a matéria o suficiente para se comprometerem com o plantão, ou ainda reclamavam que ninguém aparecia, a não ser em véspera de provas.

Em uma das últimas reuniões do ano, quando Emanuel pediu candidatos, mais uma vez eles se esquivaram dizendo que não estavam bem com a matéria e apenas Gisele aceitou prontamente. Paula disse que ainda não tinha estudado a matéria e o professor insistiu para que ela aceitasse dar o plantão e estudasse até lá, mas ela negou. Como não conseguia mais voluntários ele tentou convocar alguns monitores e pediu a Ricardo, que afirmou ter um compromisso no dia do plantão. O professor insistiu que era importante e pediu para que ele tentasse mudar o seu compromisso. Lucas também disse que não podia e Emanuel voltou a perguntar a Paula, que não cedeu de maneira alguma. Frustrado, o professor comentou que não podia mais contar com seus monitores e mudou de assunto.

Em meados de agosto, Emanuel precisou faltar ao trabalho por um dia, e então propôs um desafio aos monitores: eles dariam uma aula de exercícios no lugar do professor. Quando ele lançou a proposta, Mônica reclamou que a turma dela ainda não 
havia tido toda a matéria e ao conversar com ela sobre isso, Emanuel propôs que eles resolvessem os exercícios da lista naquele momento, durante a reunião.

Lançado o desafio, os monitores pegaram suas listas e começaram a resolvê-los individualmente. Aos poucos, alguns deles foram discutindo dúvidas com algum colega e começaram a trabalhar em duplas. Quando alguma dúvida surgia, chamavam o professor e, após uma solicitação dessas, Emanuel pediu que Ricardo tentasse resolver um exercício na lousa para ele perceber como iria se sentir nessa situação. O professor o incentivou dizendo que aquele era o momento de errar e fazer ajustes para se sentir mais seguro na hora da aula.

Após a resolução de Ricardo, o professor pediu aos monitores sugestões do que fazer para que os alunos prestassem atenção neles, afinal eles estariam sozinhos dando aula no lugar dele. Algumas sugestões surgiram, mas o assunto foi interrompido por uma pergunta sobre um dos exercícios, que era um problema conceitual. A questão era "por que o pássaro não leva choque quando pousa em um fio de luz?".

Para não dar a resposta logo, Emanuel resolveu fazer perguntas para guiar o pensamento deles, mas o que aconteceu foi que esse exercício acabou dando lugar a uma grande discussão a respeito do conceito de diferença de potencial. Conforme algumas perguntas de Emanuel iam sendo respondidas, outras dúvidas e outros problemas surgiam para o grupo resolver. Todos se envolveram muito nessa discussão e propuseram diversas explicações para o fenômeno, muitas vezes "aperfeiçoando" idéias dos colegas.

O problema acabou ficando bastante complicado e o professor também não sabia responder, então, como era chegada a hora de encerrar a reunião, Emanuel prometeu que estudaria uma maneira melhor de explicar o fenômeno a eles e depois lhes daria a resposta. Assim, ele indicou quais exercícios eles deveriam resolver na aula e encerrou a reunião.

No encontro seguinte, os comentários eram sobre como tinha sido a experiência. Emanuel pediu para que cada um contasse como se saiu e como os outros alunos se comportaram. Todos falaram que deu tudo certo, mas contaram sobre alguma dificuldade: Ricardo disse que os alunos não se interessaram muito, Paula disse que foi igual ao plantão, só que com mais alunos, Mônica disse que ficou com vergonha de ficar lá na frente, que se sentiu muito mal por estar falando e ninguém prestar atenção nela, e contou também que teve que dar bronca nos alunos. Mas, pelo relato deles, parece que o saldo da experiência foi bastante positivo. 
Um mês depois, os monitores foram novamente requisitados a atuar em sala de aula. A idéia do professor era que grupos de alunos, durante a aula de Física, construíssem um pequeno capacitor. A atuação dos monitores seria durante a aula, circulando entre os grupos e ajudando os alunos na montagem de seus capacitores. Para tanto, Emanuel levou para uma das reuniões todo o material necessário e propôs aos monitores que eles construíssem o pequeno aparelho durante a reunião, para depois, auxiliarem os alunos durante a aula.

Essa reunião foi quase toda ocupada com a construção do capacitor. O professor levou um como exemplo e explicou como montar. Cada um montaria o seu capacitor e durante o trabalho manual eles conversavam sobre assuntos diversos. Em princípio ninguém estava conseguindo fazer o capacitor funcionar, o que começou a gerar uma certa frustração entre eles. Mesmo assim, Emanuel insistia para que todos tentassem mais um pouco e aproveitava o momento de conversa durante a construção para pedir a opinião dos monitores sobre a melhor maneira de trabalhar em sala de aula.

Tatiana anunciou que conseguiu que seu capacitor funcionasse e todos comemoraram muito. Isso serviu de estímulo e eles passaram a tentar mais e com mais vontade. Enquanto todos tentavam carregar seus capacitores, Emanuel pediu que eles explicassem o funcionamento. Vários monitores participaram da discussão, com o professor estimulando o debate por meio de perguntas e devolvendo dúvidas para o grupo pensar.

$\mathrm{Na}$ seqüência, outros monitores também conseguiram que seus capacitores funcionassem e uma nova discussão foi aberta a respeito de como proceder no dia da aula. Ficou acertado que os alunos seriam divididos em seis grupos e cada grupo construiria um, mas o professor disse que ainda ia pensar melhor sobre como seria a atuação dos monitores e depois avisaria a eles.

A atividade foi feita e os monitores atuaram circulando entre os grupos, ajudando com a construção do capacitor e também ajudando a responder às questões teóricas que o professor havia proposto. Curiosamente, durante as reuniões nada foi falado a respeito de como foi essa aula, mas temos alguns depoimentos obtidos durante a entrevista.

Ah, foi bastante tranqüilo né. Como eu já tinha feito antes, eu ajudei boa parte da classe. Porque tinham algumas coisas que eles estavam fazendo errado, eu pude ajudar bastante naquela atividade. Foi uma das tarefas que eu participei, assim, dentro da classe. [...] Ah, eu me senti bem aquela hora, 
porque eu tava tranqüilo, só precisava passear pela classe e ver o que tava errado, dava pra arrumar, aí conversava com eles sobre isso. Pra mim foi bastante sossegado.

Ricardo

Então... eu acho que... achei que foi legal porque... eu até pensei na hora... "ué? Mas a gente não vai ter que fazer também?" Porque a gente já tinha feito... aí ele falou "não!" Aí eu pensei "ai que bom!" E aí acho que teve até uma coisa a mais pra gente. A gente não ficou só na parte que eles estavam fazendo... A gente fez aquilo e além... a gente ajudou... E acho que sempre que a gente ajuda uma pessoa estamos ajudando a nós mesmos. Que aí... na dúvida dele a gente tenta tirar as nossas dúvidas... até porque... como a gente é aluno... a gente tem dúvida também... a gente não sabe tudo.

Marília

Com a proximidade do fim do ano, as atividades relacionadas à recuperação se intensificaram. Assim, no final de setembro, Emanuel comentou com os monitores que pretendia controlar melhor a presença dos alunos nos plantões, para depois poder cobrar deles, pois foi oferecida uma oportunidade e eles não aproveitaram. Na semana seguinte, o professor iniciou a reunião falando quais alunos precisavam de nota e quanta nota cada um precisava. Os monitores apenas ouviam. Então, Emanuel explicou que a atividade de recuperação era constituída de um roteiro com diversas atividades que os alunos teriam que entregar regularmente, e pediu que os monitores ajudassem os alunos valendo-se de um esquema parecido com o da tutoria, de procurá-los constantemente para saber sobre o andamento das atividades. Lucas pediu para opinar e disse que achava que esse esquema não funcionaria porque os alunos não os procurariam. Gisele concordou com ele e os dois monitores conversaram sobre esse assunto com o professor até que Tatiana disse que eles não podem obrigar ninguém a fazer as atividades. Poucos monitores falaram, mas era consenso entre eles que os alunos que se interessam é que deveriam procurá-los.

A discussão continuou, mas enveredando para o lado do papel das avaliações na escola e da função da recuperação. O professor falou durante um longo tempo sobre o que ele pensava a respeito desses assuntos e os monitores ouviram com bastante atenção. No final dessa conversa, Emanuel reforçou que era importante que eles ajudassem os colegas que estavam interessados.

Nas últimas semanas de aula, a escola ofereceu aulas de recuperação para os alunos que estavam com notas baixas. Emanuel pediu que os monitores estivessem presentes durante essas aulas, pois ele pediria aos alunos para resolverem exercícios e os monitores poderiam auxiliar acompanhando os grupos de alunos. De fato, vários 
monitores compareceram à aula de recuperação e cada um sentou junto com um grupo de alunos e os auxiliou a resolver uma lista de exercícios preparada pelo professor. Uma das monitoras, Vanessa, optou por faltar ao cursinho para estar presente nesse dia.

Assim como no semestre anterior, foram três as reuniões em que se discutiram assuntos relacionados à matéria de sala de aula. Se no primeiro semestre comentamos que em geral esses assuntos surgiam naturalmente, dessa vez foi o professor que perguntou o que eles estavam achando das aulas, se estavam entendendo a matéria, e isso desencadeou as discussões. Dessa vez não foram reclamações que predominaram, mas sim perguntas sobre a seqüência do curso e sugestões, como por exemplo dar mais listas de exercícios e usar menos transparências nas aulas.

A última conversa desse tipo ocorreu na reunião do dia 23 de setembro e foi interessante porque inicialmente o professor perguntou se eles estavam entendendo a matéria, mas em seguida aproveitou para perguntar como estavam as aulas de Física. Com isso, ele conseguiu muitas informações importantes sobre como os alunos estavam encarando esse finalzinho de terceiro ano. Toda essa discussão acabou culminando em um aviso do professor de que na semana seguinte a atividade para montar um capacitor seria realizada em sala de aula. Nesse momento, Vanessa aproveitou para revelar que estava com muita dificuldade em entender a bateria. O professor devolveu essa pergunta para o próprio grupo, tentando envolver a todos nessa discussão. A partir daí, Mônica disse que não estava entendendo o capacitor e novamente o professor devolveu a pergunta para o grupo. Poucos se envolveram nessa discussão, tentando esclarecer os conceitos, mas a situação acabou revelando várias dúvidas a respeito dessa matéria.

No desenrolar da discussão, Emanuel acabou lançando um pequeno desafio para os monitores, um problema sobre capacitores que ele inventou naquela hora e cuja resolução se estendeu até o final dessa reunião. Apesar de parecer que esse seria um grande momento de interação entre todos, os monitores se empenharam pouco em tentar resolver o problema. Na tentativa de estimulá-los a participar, o professor se remetia a alguns individualmente, fazendo perguntas e, assim, acabou se tornando o ponto de convergência das falas.

Assim como no primeiro semestre, as discussões que mais instigaram a participação de todos foram aquelas que eles consideravam "descontraídas", os momentos em que eles conversavam sobre assuntos não necessariamente relacionados ao trabalho deles como monitores. No segundo semestre esses momentos de conversa foram bastante constantes nas reuniões. 
Logo no primeiro encontro após as férias, Emanuel perguntou a eles quais eram as expectativas para o semestre. Todos falaram sobre seus planos e angústias da reta final do Ensino Médio. Mônica comentou que no final do ano pretendia "abandonar" a escola e ficar só estudando para o vestibular. Lucas falou de sua dificuldade em escolher o curso para o qual prestaria o exame, ele disse que gostaria de fazer artes cênicas, mas isso não "dá dinheiro", então ele estava pensando em fazer direito, ou biotecnologia, ou diversos outros cursos que nada tinham a ver uns com os outros, e a conversa acabou tendo seu foco na escolha da profissão. Emanuel contou como foi a sua experiência até decidir ser professor, e os monitores ouviram muito atentamente, pois ele havia trilhado outros caminhos profissionais antes de encontrar aquele que realmente o satisfazia: a docência.

O vestibular acabou sendo foco de muitas conversas ao longo do ano. Em outro encontro, Lucas comentou que ao pegar o manual da FUVEST começou a chorar porque não sabia nada dos conteúdos listados lá. Esse comentário acabou gerando uma interessante discussão a respeito de notas, estudos e possíveis desempenhos no vestibular.

Em outros dois momentos foi o professor que desabafou com os monitores. Em um deles, ele comentou sobre os problemas que estava enfrentando por ter uma quantidade de trabalho muito grande e não estar dando conta de corrigir as provas e trabalhos, e também falou de sua preocupação com o trabalho trimestral. Os monitores o incentivaram a desabafar com eles e se solidarizaram com o professor, dando apoio a ele.

Em outro momento, Emanuel estava muito chateado porque havia constatado que todos colaram na prova de Física. Ele chegou muito desanimado à reunião e comentou sobre isso com os monitores. A conversa sobre a cola acabou gerando uma longa discussão sobre notas e tipos de questões das provas.

A viagem de formatura que se aproximava também foi assunto recorrente nas reuniões. Emanuel se preocupava com os efeitos que a viagem teria sobre os estudos do pessoal, por isso ele perguntava aos monitores como estavam as expectativas e eles discutiam sobre o que poderia ser feito para que o pessoal focasse novamente nos estudos.

Além disso, houve espaço para pequenas festas. No dia do aniversário de Nely houve bolo e refrigerante e alguns minutos da reunião dedicados a festejar a data. $\mathrm{E}$ mesmo fofocas da escola tinham espaço durante a reunião, como no dia em que duas 
meninas tinham brigado fisicamente na escola, rendendo muitos comentários durante o encontro da monitoria, pois Emanuel não assistiu à briga e os monitores queriam contar tudo a ele em detalhes, comentando sobre os motivos e consequiências da briga.

\section{Algumas reflexões sobre a formação deste grupo}

No quarto ano de projeto, Emanuel novamente convocou os monitores para constituírem um grupo. Todos os oito alunos convocados no primeiro momento, logo após a análise dos questionários de indicação, já haviam sido monitores em alguma das edições anteriores do projeto. A maioria deles fez parte do grupo de 2003, que apresentamos no capítulo anterior, mas alguns passaram a integrar o grupo apenas no ano seguinte, durante a monitoria inter-séries.

Diante disso, devemos levar em conta que esses monitores atenderam à convocação do professor já sabendo o que é a monitoria e com a bagagem da experiência vivida anteriormente. Se em 2003 era muito fácil que eles, inicialmente, estivessem presos ao discurso do professor e àquilo que ele concebia como importante para a monitoria, neste novo ano eles já chegam ao grupo com suas próprias idéias a respeito do trabalho de monitor. Não era mais apenas a palavra do professor e suas idéias e propostas que valiam, mas tudo o que eles aprenderam e desenvolveram nos anos anteriores também contribuiu para sua decisão de integrar a equipe novamente.

Então, o grupo se funda novamente a partir da convocação do professor com o objetivo de ajudar os colegas. Mas não podemos ignorar a experiência anterior desses alunos e alguns pontos devem ser considerados. O grupo todo fez parte da experiência de 2003 e chega em 2005 com identificações construídas e representações de como é o trabalho da monitoria, pautadas por sua experiência pregressa. Isso é uma peculiaridade importante, embora devamos lembrar que o grupo conta com menos integrantes e está inserido em um novo contexto.

De fato esses monitores chegam em 2005 já bastante entrosados e seguros com relação ao seu trabalho. Em entrevista, eles relatam sua angústia quando da primeira convocação para a monitoria, nas edições anteriores, quando eles ainda não sabiam muito bem o que deveriam fazer, e seu medo que assumindo esse compromisso eles fossem ter responsabilidades muito grandes. Ao mesmo tempo, dizem que no terceiro ano a decisão de participar tinha sido mais tranqüila porque eles já sabiam como as coisas funcionavam. 
[Quando o professor convocou no primeiro ano] eu não queria ser. Porque eu achava que é responsabilidade, achava que eu não ia conseguir. Eu falava "não psor, não quero não. Olha os outros alunos, eu não sou boa". Eu tinha uma nota mediana, mas eu não... eu sei bem, sei explicar... não queria ser. Mas aí depois que você entra, vê como realmente é, você começa a gostar. Mas eu achava muita responsabilidade. Muitos, o professor convidou muitos alunos também esse ano e eles não queriam porque eles achavam muita responsabilidade. [...] [Esse ano] É muita responsabilidade, mas que não me incomoda.

Vanessa

[...] aí ele perguntou se eu queria. Aí, tipo, no começo eu achei meio, meio esquisito, sabe? Nem curti muito a idéia e já falei que eu não queria, mas depois eu pensei bem e falei: "Ah, vou me esforçar, vai." Tipo, mais como desafio do que como vontade, assim. Entendeu?[...] No segundo [ano] eu continuei, aí eu gostei, vi que não era nenhum bicho de sete cabeças e continuei.

Tatiana

[A expectativa em 2005] era a mesma. Até porque você já conhece e eu disse "ah, acho que é a continuação do que era".

Paula

Portanto, percebemos que os integrantes desse novo grupo chegam mais seguros e certos do que querem. A experiência vivida anteriormente influencia no desenvolvimento grupal, uma vez que pode balizar atitudes e desejos.

\section{INTERPRETAÇÃO DO DESENVOLVER GRUPAL}

A partir da observação do grupo durante todo o ano, das entrevistas feitas e de conversas informais, nos surpreendemos com a diferença de resultado obtido em relação aos anos anteriores da monitoria. Ficou claro que não havia planejamento do professor e que faltava empenho dos monitores nas tarefas relacionadas a ajudar os colegas. As reclamações eram constantes, inclusive sobre atividades que tinham sido muito bem sucedidas no passado e que já tinham sido realizadas por esses mesmos monitores.

Nossa expectativa de encontrar um grupo operativo, caminhando da pré-tarefa para a tarefa e então para o momento do projeto, não se realizou. Pelo contrário, encontramos um grupo aparentemente estagnado, que não resolvia os problemas surgidos, que não inovava em suas funções e que parecia se contentar em fazer o mínimo possível. Enquanto que nos anos anteriores os grupos pareciam bastante envolvidos em solucionar os problemas que surgiam, em favor de uma monitoria mais bem estruturada e com mais possibilidades para ajuda aos colegas, no ano de 2005 o 
grupo parece querer se livrar das tarefas envolvendo os alunos e apenas valoriza aquelas que ajudam o professor.

Então, eu entrei na monitoria no primeiro ano, teve a seleção lá que a gente já falou. [...] Aí esse ano ele chamou de novo, ninguém mais queria ser também né. Aí eu acabei sendo. E esse ano até... pode-se dizer que teve um pouco menos de compromisso, porque não tem mais aquela obrigação da reunião em grupo, tal... vem dar plantão a tarde quando pode, então é um pouco mais leve. Aí tem as reuniões de sexta também e quando você pode, você fica pra dar o plantão também, mas... também é bem legal.

Paula (grifo nosso)

Em entrevista, Paula conta sobre sua entrada na monitoria em 2003 e seu retorno ao projeto em 2005. Fica evidente que neste ano existe algo diferente na monitoria, o compromisso exigido não foi o mesmo que nas edições anteriores.

Tatiana: Olha, eu acho que podia ser mais do que já foi. Os outros anos, tipo a monitoria foi mais, foi mais intensa, o pessoal colaborou mais com alunos aqui da sala, esse ano eu achei que ficou meio... como que eu posso falar. tipo... meio falta do que fazer... falta do que fazer não, mas, podia ter rendido mais. Eu acho que... que o pessoal não tava interessado, a gente tava muito, na monitoria, preocupado com o vestibular, mas eu acho que poderia ter rendido um pouco mais do que rendeu.

Pesquisadora: Em que sentido, render mais?

Tatiana: Ajudar as pessoas... é... a intenção da monitoria é ajudar o pessoal né... e acho que a gente não conseguiu fazer muito isso.

Tatiana, assim como Nely no trecho abaixo, também comparam as edições de monitoria que vivenciaram explicitando que as coisas tinham mudado e o projeto não funcionava mais como antes.

[Esse ano] acho que a gente não teve tanta interação com os alunos, de explicar matéria, como foi no outro ano, mas eu acho que ajudou muito o Emanuel, pra ele dar conta de passar o conteúdo, de saber o que estava acontecendo com as pessoas.

Não nos parece que tenha havido uma continuidade do projeto anterior, mas sim que houve uma ruptura; algo aconteceu que desmobilizou o professor e os monitores de uma evolução grupal em busca da autonomia e da criatividade. Diante disso, nesta seção, vamos analisar alguns aspectos importantes da monitoria no ano de 2005 , buscando entender o processo pelo qual este grupo passou. 


\section{Relações Estabelecidas}

Se todas essas mudanças ocorreram no projeto de monitoria, se a novidade e criatividade apresentadas nas edições anteriores não apareciam mais nesta quarta edição, nos perguntamos por que esse grupo continuava investindo na monitoria. A ruptura ocorrida os desmobilizou para seu trabalho de ajuda aos colegas, mas não causou o desmantelamento do grupo.

\section{As Reuniões}

No meio do ano nos deparamos com um fato curioso envolvendo uma das monitoras. Vanessa, que participava do projeto desde 2003, anunciou no final do primeiro semestre que não iria mais participar da monitoria porque começaria a fazer cursinho pré-vestibular no período da tarde e assim não seria mais possível para ela freqüentar as reuniões de monitoria e nem mesmo dar plantões de dúvidas. Mas o que aconteceu foi que ela não compareceu à primeira reunião do segundo semestre, mas logo em seguida voltou a participar desses encontros semanais. Realmente ela avisou que o plantão seria impossível, porém continuou a freqüentar a reunião.

Esse movimento da monitora é bastante interessante, pois ela não poderia mais contribuir ajudando os alunos com dificuldade (que podemos pensar como sendo a principal atividade dos monitores), mas ela continuou freqüentando as reuniões até o final do ano, sempre participando muito ativamente.

Pesquisadora: Você tinha dito que talvez você não fosse mais participar do projeto de monitoria. Por causa do cursinho?

Vanessa: É, porque eu não ia ter tempo de fazer plantão, mas deu tempo de conciliar com as reuniões.

Pesquisadora: Então plantão você não deu mais depois que você começou o cursinho?

Vanessa: Plantão eu não dei mais, só dei um dia que teve o... o... ai, a recuperação paralela do professor, que aí ele precisava de sempre uns dois monitores pra ajudar. Aí teve um dia que eu vim... foi legal, consegui ajudar as pessoas assim...

Pesquisadora: E por que você não parou de vir à reunião então?

Vanessa: Ah, então, porque eu acho legal essa interação de todos os monitores, de vê o que ta acontecendo, de poder ajudar, de poder reclamar... 
Percebemos pela entrevista que Vanessa gostava bastante das reuniões de monitoria, como também é evidenciado em outro trecho:

Pesquisadora: Por que você gosta de ser monitora?

Vanessa: Ah, eu gosto principalmente das reuniões, de dar opinião minha assim, sobre como tá o andamento das aulas. Falar das pessoas o que elas tão achando. Das reuniões é a parte que eu mais gosto. [...]

Perguntamos a todos os monitores a respeito da reunião de monitoria e todos disseram gostar muito dela, pois se tratava de um ambiente agradável, que tinha um clima informal e que permitia que eles conversassem sobre vários assuntos.

Eu gosto... Ah, as discussões são bem descontraídas, todo mundo se dá bem lá, ninguém tem problema com ninguém, então, dá pra conversar legal com cada um. Isso é gostoso, me sinto bem lá.

Ricardo

É importante até estar passando pro professor o que os alunos estão achando, o que os alunos estão pensando, e ela não é chata... você vê, ninguém vem arrastado pra cá, sabe? Você ri, você tem bolacha, você come... [risos] Então é tranqüilo assim. É bom pra discutir... É um tempo que você tem que ter pra poder discutir o que está acontecendo, pro Emanuel passar tudo que ele está achando, o que você precisa fazer... é importante.

Nely

Ah, ficar sabendo de algumas coisas antes de elas acontecerem né, trabalhos... já vai se preparando antes. Acho que principalmente isso que eu acho mais interessante.

Ricardo

[...] tem a reuniãozinha sexta feira, mas é uma coisa dinâmica, você fala e é tipo uma conversa mesmo e eu acho que nessa conversa surgem mais coisas que só sua obrigação, como eu pensava que era.

Marília

Na reunião? Ah! Eu acho legal porque é uma coisa descontraída, parece às vezes que nem é, tipo, professor e aluno, aquela coisa, às vezes é tipo amigo, parece amigo que está... conversando... então a gente conversa de tudo que precisa conversar, mas de uma maneira descontraída. Por isso que eu acho que às vezes se fosse uma coisa por obrigação que nem eram as outras monitorias seria diferente assim tipo... eu não falaria tanto.

Marília

[As reuniões] eu adoro! Eu acho muito divertido, acho muito legal! É que eu adoro conversar, e eu acho que a gente tem liberdade de falar tudo o que 
a gente precisa, e tem umas pessoas que eu gosto, mas que eu não falo direto [...] e eu gosto de estar com eles, me sinto bem em estar com eles.

Mônica

\section{O Professor}

Ainda com as entrevistas, foi possível perceber que a proximidade com o professor é um fator muito importante para a permanência deles na monitoria. Em algum momento da entrevista todos explicitaram que gostavam da relação mais próxima com ele proporcionada pela monitoria, que gostavam de ajudar o professor a decidir os trabalhos ou mesmo ajudá-lo informando sobre as dificuldades da turma. Alguns trechos de entrevista deixam esses pontos mais evidentes:

As reuniões eu adoro! Eu acho que foi bom também por poder conhecer melhor o professor. Tipo, ele é muito gente boa, assim, sabe? Quando tem uma relação só de professor você percebe, mas nem tanto assim. E por poder ajudar ele. A gente ajuda muito fazendo isso.

Mônica (grifo nosso)

[Depois de entrar para a monitoria] Eu acho que ficou mais próximo. Eu não conhecia o Emanuel do primeiro colegial como todos conheciam, porque eu era de outro colégio, então, era um professor novo pra mim, eu fui ver, gostei, mas eu não tinha muito contato com ele, depois que o Silvio [outro monitor da mesma turma que Ricardo] me chamou pra monitoria e eu comecei a conversar mais com o Emanuel, ficou mais próximo né, trocava idéia com ele direto. [...] De vez em quando você tem problema com a matéria, se você já tem um relacionamento mais aberto com o professor, fica mais fácil você chegar nele e... tirar uma dúvida e qualquer outro problema.

Ricardo

Uma das coisas mais válidas esse ano, além de poder ajudar, foi poder estar mais próxima do Emanuel, ter mais contato com ele, conhecer ele melhor. E acho que foi muito legal estar junto com ele nesse processo dele de adaptação pro terceiro ano, eu acho que é uma coisa que deu pra ajudar bastante.

Nely

Algumas entrevistas foram feitas em pequenos grupos e em uma delas, com Tatiana, Vanessa e Paula, é possível perceber que para elas a monitoria é também uma oportunidade de aproximação com o professor:

Pesquisadora: E a relação com o professor, como é?

Vanessa: Muito boa, muito boa! (responde sorrindo e todas concordam com a cabeça) 
Tatiana: É, a gente vê uma pessoa diferente aqui do que é na sala de aula.

Vanessa: [...] Eu me sinto no direito de reclamar qualquer coisa com ele, que ele vai saber escutar.

É claro que eles também afirmam que se sentem bem em ajudar os colegas e por isso gostam de serem monitores. Porém, é muito marcante a importância da proximidade com o professor que a monitoria proporciona para eles. Nesse ano, mais do que desenvolver as tarefas da monitoria, eles estão interessados em manter essa relação de proximidade com o professor.

Ao longo do ano, observamos diversas reclamações deles no que dizia respeito a alguns aspectos da monitoria mais ligados ao seu contato com os outros alunos. Em diversas situações eles reclamaram da tutoria, da recuperação e até mesmo se recusavam a dar o plantão.

No início do segundo semestre, quando o professor pediu para que os monitores procurassem os alunos novos de suas turmas para perguntar o que eles já tinham aprendido em Física e deixá-los a par do que estava sendo aprendido na escola, Paula não havia procurado o aluno pelo qual ela havia ficado responsável. Em outra situação, Emanuel pedia algum monitor para dar um dos plantões e perguntou se Paula poderia ir e ela negou; o professor insistiu, mas ela não cedeu. Em entrevista ela comenta que deu apenas um ou dois plantões durante o ano todo. Com relação à tutoria também aconteceu de Emanuel cobrá-la sobre seu tutorado e a menina dizer que não havia procurado o aluno. Podemos interpretar que nessas diversas situações Paula foi portavoz do grupo, revelando explicitamente um desejo grupal: eles não queriam procurar os alunos para ajudá-los; eles estariam à disposição, mas não queriam ir atrás.

O porta-voz, devido à sua história pessoal, é sensível ao problema subjacente e detecta as fantasias, necessidades ou ansiedades do grupo, explicitando-as. O que é explicitado é também um problema do grupo - produto da interação dos membros entre si e com o coordenador - e por sua história pessoal, o porta-voz se identifica com aquele conteúdo e o enuncia.

Às vezes o porta-voz expressa a resistência à mudança, que o grupo adota como defesa diante da ansiedade que se produz, diante do sentimento de insegurança. Paula traz à tona um enunciado do grupo, de não envolvimento com as tarefas ligadas a ajudar os outros alunos.

Ao mesmo tempo, percebemos que uma atividade muito marcante para eles foi a ajuda ao professor. Em muitos momentos eles foram requisitados a opinar nos trabalhos 
trimestrais, no planejamento das aulas, em datas e prazos para avaliações e era nítida a mudança de postura deles durante esses momentos. Enquanto que quando falavam de seu trabalho na monitoria, relatando o desenvolvimento de seus tutorados, ou tirando dúvidas da matéria, ou falando sobre a correção das listas, o modo de interação era monitor-professor, sem interação com os outros monitores, quando o assunto era ajudar o professor essa interação dual se dissolvia e todos passavam a opinar e trabalhar em conjunto para resolver o problema colocado.

[...] é... essas tarefas trimestrais que tem o professor ouve as nossas opiniões, o que a gente acha, o que seria melhor, adequado. Por exemplo, teve um exemplo que a gente pediu que as atividades mesmo ocorressem em sala porque tem muita dificuldade de reunir todos os alunos fora do colégio. É mais isso também.

Vanessa

[...] E o que eu mais gosto... o que eu mais gosto é de dar opinião quando o Emanuel pede ajuda pra decidir sobre os trabalhos né... que a gente deve fazer e tudo mais, o que eu mais gosto é dar opinião mesmo e ajudar ele a ver qual a melhor forma de dar o trabalho depois.

Ricardo (grifo nosso)

[...] e é uma maneira de ajudar o Emanuel né, porque ele se sobrecarrega demais com as coisas, então acaba aliviando pro lado dele também.

Nely

E é mó legal porque... não é só isso de você ser monitora e ajudar os seus amigos. É uma coisa a mais, você ajuda o professor também, auxilia ele no que você pode e tal. E eu gostei bastante, é mó legal. Eu gosto porque aí você tem uma liberdade de falar as coisas também com o professor que você não tem normalmente na sala de aula e na reunião de monitoria você tem, porque é uma coisa mais fechada.

Marília

Esse ano foi mais tranqüilo, foi mais uma assessoria ao Emanuel mesmo, não foi uma coisa mais ligada às pessoas, era mais um trabalho de observação de como a pessoa se comportava e passar essas informações, passar a minha visão como aluna para o Emanuel, pra daí ele tratar diretamente com os alunos. Eu acho que foi mais esse, o papel.

Gisele

O professor, aos poucos, abriu espaço para os monitores se aproximarem ainda mais dele. Primeiro ele começou a levar as bolachas recheadas ao encontro, conferindo um ar mais informal e proporcionando um ambiente acolhedor durante as reuniões. As festas de aniversário também contribuíram para um ambiente ainda mais próximo entre monitores e professor. Os momentos em que Emanuel enfrentava problemas e 
desabafava com os monitores também contribuíram para que eles se sentissem responsáveis pelo professor.

Nos parece que as atenções dos monitores começaram a ficar cada vez mais voltadas a ajudar o professor em seu trabalho (planejando aulas e trabalhos escolares) do que ajudar os colegas e pensar estratégias que pudessem melhorar a eficiência da monitoria.

Quando o assunto é "ajudar o professor" o grupo muda sua postura, participando mais e se empenhando nesse objetivo. Como dito anteriormente, a modalidade dual de interação se desfaz e eles debatem os problemas, propondo soluções.

\section{Saber e Poder}

A proximidade com o professor proporcionada pela participação no projeto de monitoria aparece nas falas de todos os monitores. É perceptível que ajudar o professor em seu trabalho era tarefa das mais importantes para os monitores e esse fato pode estar diretamente relacionado a essa relação estabelecida entre monitores e professor. E não apenas os monitores valorizam muito essa relação, mas o próprio professor coloca isso como sendo um dos grandes ganhos da monitoria.

O gostoso é essa relação que fica né, professor-aluno, eu acho que é... essa relação eu acho que é... ela já por si só é muito... é um grande ganho. [...] Mas o ganho significativo mesmo foi... eu acredito ter sido em função dessa relação... com os monitores.

Emanuel

Diante disso, e nos lembrando ainda que o modo de interação dentro desse grupo era essencialmente dual (professor-monitor), formulamos a hipótese de que o grupo se mantém unido para manter a relação individual com o professor.

Se a monitoria não existisse, nenhum deles teria espaço para manter essa relação próxima com ele. Sem a monitoria eles não poderiam opinar sobre o trabalho do professor, reclamar e sugerir com tanta liberdade. A única forma de manter esse espaço de proximidade com ele é mantendo-se em grupo.

O que nos perguntamos diante dessa hipótese é: o que essa proximidade com o professor garante a eles?

Os monitores sempre dizem que querem estudar mais e sempre estão em busca de melhorar. Inclusive deixam claro que a identificação dos membros do grupo está 
fortemente marcada pela questão do conhecimento e do interesse em saber cada vez mais.

Você assume um compromisso com você mesmo, e a monitoria tem que estudar mais Física. [...] tem o negócio de você querer ajudar os outros, mas também é muito pra mim, assim... eu gosto porque me faz estudar mais, me faz entender mais.

Vanessa

Mas eu gosto sim, porque eи me preocupo mais, assim, sabe? Eu estudo mais, eu corro mais atrás e dá pra aproveitar mais assim, de correr atrás e ainda ajudar os outros, né.

Mônica

Ah, eu gosto, eu acho que aprende mais, assim explicando pros outros.

Lucas

Aí você se esforça um pouco mais, e isso eu acho bom. E ainda ano de vestibular ajuda a forçar um pouquinho mais também.

Paula

[...] eu gosto de estar entre o pessoal que é interessado, que é estudioso, tipo é legal encontrar com todo mundo na sexta feira sabe... eu gostei...

Tatiana

O que eu mais gosto, pra mim, é que eu estudo mais pra explicar pros outros [...]

Mônica

Assim, a monitoria pode proporcionar uma proximidade com o saber através do professor.

É claro que numa situação escolar o professor é a figura de referência de conhecimento, afinal é ele a pessoa incumbida de guiar os estudos dos alunos. Por isso, os monitores, em busca do saber, procuram valores depositados no professor que estão ligados ao conhecimento.

Dessa forma, podemos entender melhor a dinâmica de interação dentro do grupo, em que cada monitor falava quase que exclusivamente com o professor. Agindo assim eles estão preservando a hierarquia com relação ao saber. A pessoa em quem o conhecimento é depositado é o professor, e apenas ele pode responder pelos problemas enfrentados. As falas acabam individualizadas porque eles mesmos não vêem entre seus colegas alguém capaz de ajudá-los, uma vez que em relação ao saber, todos os monitores se encontram no mesmo nível hierárquico. 
Neste grupo, a relação estabelecida se dá na forma de filiação, ou seja, o professor é o detentor do saber e confia aos monitores a possibilidade de transmitir esse conhecimento para os outros alunos. Os monitores têm a possibilidade de conviver mais de perto com essa figura de referência, ao mesmo tempo se sentem valorizados pela confiança que o professor deposita neles e, assim, mantêm a hierarquia com relação ao saber.

Por outro lado, os monitores ganham também status na instituição através da monitoria. Depois das experiências muito bem sucedidas dos anos anteriores, o projeto já era conhecido na escola e os comentários eram todos favoráveis. Alguns professores de outras disciplinas também acabaram por aderir à monitoria, montando seu próprio esquema de funcionamento e convocando os monitores de acordo com os critérios que achavam mais interessantes. O fato é que, até então, a monitoria era considerada uma ótima experiência.

Ao contrário do que ocorreu nas edições anteriores, desta vez os monitores quase não faziam novas propostas para a monitoria no que dizia respeito ao seu trabalho com os outros alunos. O que nos parece é que desta vez eles não estavam interessados em novidades, pois já tinham um status que foi adquirido anteriormente, e agora era necessário apenas se manter nesta posição de destaque. Novidades podem ser ameaçadoras ao grupo, pois nunca se sabe se serão bem sucedidas, por isso era muito mais interessante simplesmente manter a posição já alcançada, fazendo o mínimo para parecer que a monitoria funcionava.

Mais uma hipótese é a de que eles queriam ser objeto de reconhecimento. Pode ser um reconhecimento institucional, mas também pode ser um reconhecimento pelo professor, que confirma que eles são bons, já que se trata da figura de referência com relação ao saber ouvindo suas opiniões e confiando a eles parte de seu trabalho. Sendo assim, a monitoria proporciona a eles um poder dentro da instituição.

Quando os monitores opinam sobre os moldes da disciplina e o professor os ouve e tenta se ajustar às suas sugestões, eles conseguem poder institucional. Embora sejam "apenas" alunos, eles têm lugar de destaque, pois têm poder para sugerir mudanças e a certeza de que são ouvidos.

Por outro lado, eles também vivenciam o poder diante de seus colegas. Nas entrevistas também é possível perceber que muitos deles se referem à Física como uma disciplina difícil, e essa é uma opinião bastante comum entre os discentes. Saber Física 
dá mais status a eles, pois os colegas os admiram por serem monitores de uma matéria tão difícil.

[...] é uma coisa que eu acho interessante, a física. Eu acho que física é uma coisa pra responder umas coisas que a gente nunca entendeu. Eu acho difícil... pra mim nem tanto mas talvez pros meus amigos, que é difícil entender, que é muito difícil assim você pensar e imaginar uma coisa que você não consegue ver, tipo um elétron e tal, essas coisas, é difícil de pensar e aí que eu acho que a física pega todo mundo, e aí o pessoal acha que a física é um bicho de sete cabeças.

Marília

Eu acho que eu quero ser professora quando eu crescer. [...] eu queria muito gostar de física pra ser professora de física, só que eu acho uma matéria muito difícil. Então acho que exige muito... assim, precisa ter muito dom pra você conseguir dar a física. Eu queria... eu queria... conseguir ensinar física pros meus alunos, que é muito difícil. Mas eu gosto muito de humanas: literatura, história, história da arte... então acho que eu vou seguir alguma coisa ali.

Nely

A física é uma coisa que quando você fala de física os alunos já olham já de um jeito...[faz uma cara feia] e... é uma das matérias que é um horror pra qualquer um.

Marília

Assim, percebemos que as relações que foram se estabelecendo ao longo desta edição da monitoria marcaram fortemente esse grupo e sua tarefa. As relações afetivas estabelecidas, que já vinham desde uma experiência anterior, marcaram o modo de funcionamento do grupo, fazendo com que ele se diferenciasse fortemente daquele dos grupos anteriores. Aquela experiência permitiu que esses monitores vivenciassem o sucesso, o poder institucional e perante os colegas e a aproximação do saber através da figura do professor simpático, aberto, que sabia ouvir, em quem eles podiam confiar, e que confiava neles também.

Tudo isso contribuiu para que houvesse uma mudança de foco muito significativa. O grupo muda sua tarefa. Fica claro que o objetivo inicial, de desenvolver a monitoria e ajudar os colegas com dificuldade, deixa de existir. Uma nova tarefa é instituída dentro desse grupo, mesmo que não verbalmente, modificando sua estrutura e seu desenvolvimento. 


\section{A Nova Tarefa}

A nova tarefa elegida pelo grupo é a de continuar juntos. Não existe mais um problema para ser resolvido em conjunto; os monitores e o professor querem apenas manter a relação estabelecida e usam o espaço da monitoria para se manterem próximos. Enquanto que num grupo operativo os membros ficam juntos para resolver a tarefa, nos parece que na monitoria, eles fazem a "tarefa" para ficarem juntos.

O "ficar juntos" traz uma série de benefícios para esses monitores: eles se encontram às sextas-feiras, conversam, se distraem, comem, se aproximam do professor, ficam sabendo de todas as atividades antecipadamente, fazem os trabalhos escolares antes dos outros alunos com uma assistência mais próxima do professor, opinam no planejamento do curso e são ouvidos, compartilham experiências com o professor e com alunos que são estudiosos como eles, adquirem status, poder institucional e ainda ganham nota para isso!

A imagem da monitoria já estava construída, a posição de destaque já era dada mesmo antes do início de sua atuação no ano de 2005, a relação afetiva entre eles e, principalmente com o professor, já tinha sido consolidada anteriormente e eles já sabiam que o espaço de monitoria poderia lhes oferecer todas essas vantagens. Diante disso, ocorre o deslocamento da tarefa. O interesse em "ficar junto" supera a busca pelo objetivo.

Mas e o professor?

Também é possível perceber que ele investe na monitoria muito menos do que tinha feito nos anos anteriores. Nossa sensação ao final do processo era a de que não havia planejamento das reuniões e nem das atividades que seriam propostas aos monitores, parecendo que ele deixava as coisas acontecerem e ia tomando as decisões durante as reuniões. Seu investimento ainda é forte na palavra, mas fraco nas ações.

Devemos lembrar que de 2002 a 2004 a monitoria também era objeto de pesquisa de Emanuel para sua pós-graduação. Em 2005 seu mestrado já estava concluído, e poderíamos pensar que seu investimento na monitoria diminuiu em função disso. No entanto, ele já tinha formulado um projeto de doutorado - e o grupo de monitores de 2005 era seu objeto de pesquisa.

Com o início do doutorado, Emanuel conseguiu uma bolsa para ministrar aulas na graduação na Universidade de São Paulo. Ele trabalhou em dois cursos, um no primeiro e outro no segundo semestre de 2005. Esses cursos de graduação foram alvo de 
grande investimento para Emanuel, pois era um novo desafio ministrar aulas no ensino superior, para uma turma de licenciatura em Física, em cursos que visavam discutir o papel do ensino de Física. Diversas vezes ele relatou, em conversas informais e mesmo dentro das reuniões semanais, que ele estava com muito pouco tempo para o planejamento da monitoria, e mesmo para correção de tarefas de seus alunos do Ensino Médio, porque as aulas da faculdade estavam exigindo bastante dedicação dele.

Percebemos que as aulas na universidade passaram a ser um grande desafio para ele, assim como a monitoria já havia sido um dia. Existiu um deslocamento de parte da energia que era destinada à monitoria, para esta nova e desafiadora atividade do professor.

Além disso, Emanuel estava tendo problemas com a instituição. Diversas vezes ele disse que estava cansado daquela escola, pois a direção e coordenação não davam apoio aos professores e ele não concordava com muitas das orientações dadas pela direção. Ele estava bastante descontente e constantemente entrava em atrito com a coordenadora. Como na ocasião da coleta de dados, a relação dele com a instituição não era foco de nosso interesse, nada foi perguntado a ele em entrevista a respeito desse assunto. No entanto, o descontentamento e os atritos foram crescendo tanto que Emanuel comentou sobre sua relação com a instituição durante a entrevista que fizemos com ele no final de 2006:

[...] na sofreguidão do colégio lá, com as desorientações pedagógicas que acontecem lá e os questionamentos com relação a isso, aquilo e aquele outro $[\ldots]$

Tem a expectativa de eu sair do colégio, ir para um outro colégio. Eu estou torcendo pra isso. Obviamente não por causa dos alunos, mas por causa das minhas críticas com relação à organização do colégio e pra mudar de experiência.

Eu estou de saco cheio do colégio e acaba influenciando isso daí. Vai ficar muito ruim se eu tiver que ficar lá mais um ano...

Ainda no âmbito da instituição, percebemos, por nossa vivência no campo de pesquisa, que a escola admitia a monitoria como um bom projeto, mas que nunca houve um reconhecimento concreto do esforço de Emanuel. Exemplo disso é que todo final de ano o professor entregava um certificado de monitoria aos participantes, mas era um certificado confeccionado por ele, pois a escola não conferia este tipo de reconhecimento ao trabalho desenvolvido. 
Ainda, muitas vezes, Emanuel comentou seu desejo de que outros professores desenvolvessem também seus projetos de monitoria, já que a experiência vinha dando tão certo. É importante ressaltar que Emanuel sempre dizia que cada professor deveria desenvolver o seu próprio modelo de monitoria, que atendesse às necessidades da sua disciplina e que se adequasse à sua personalidade e à sua maneira de trabalhar. Isso nos remete a um desejo seu de uma institucionalização da monitoria, que não deixa também de ser um desejo por reconhecimento.

Não sabemos exatamente o teor do problema de Emanuel com a instituição porque este não havia sido alvo de nossa investigação; no entanto nos parece claro que a relação professor-instituição foi sendo minada, o que pode ter tido reflexo em seu empenho no projeto de monitoria.

Diante desses problemas enfrentados pelo professor - novo desafio (as aulas na faculdade) e um crescente desentendimento com a instituição - ele acaba também aderindo à mudança de tarefa.

Podemos pensar o professor como o coordenador do grupo. Portanto, cabe a ele identificar os momentos de desvio da tarefa proposta e intervir na tentativa de trazer o grupo novamente para o seu objetivo explícito. Pichon-Rivière (1994, p. 21) alerta para o risco de o coordenador de um grupo confundir a pré-tarefa com a tarefa, pois assim "sua tarefa converte-se em pré-tarefa, ao ter ele mesmo resistência a entrar em sua tarefa específica, por evitar o problema essencial do tornar-se responsável, do 'compromisso', do ser consciente e do projeto". Extrapolamos esse alerta de Pichon para a possibilidade de que o coordenador, como membro do grupo, esteja suscetível a grandes angústias diante do novo trabalho e acabe por deixar a tarefa de lado, se restringindo a apenas "estar em conjunto". Portanto, quando Emanuel se envolve com outras questões e se desilude com a instituição, ele também renuncia à evolução da monitoria e acaba por se restringir à manutenção daquele espaço, para ficar junto dos monitores.

Quando a vontade de simplesmente ficar junto supera a busca pelo objetivo o grupo deixa de ser operativo, uma vez que "o grupo operativo é um grupo centrado na tarefa, que tem por finalidade aprender a pensar em termos da resolução das dificuldades criadas e manifestadas no campo grupal" (PICHON-RIVIÈRE, 1994, p. 105).

Foi estabelecida uma dependência mútua nesse grupo: monitores dependem do professor, e este por sua vez, depende dos monitores. O fato é que as reuniões de 
monitoria proporcionavam a esse grupo um ambiente liberto de angústias, onde se podia falar à vontade, sobre qualquer assunto, ter um momento agradável com outras pessoas com quem se identificavam, e onde se estava seguro atrás de um status já alcançado. Novas atividades, novos desafios, novas preocupações poderiam tirá-los de posição tão privilegiada.

Seria natural que ansiedades surgissem no início desse grupo, caracterizando a pré-tarefa, principalmente pelo medo da perda do sucesso já obtido anteriormente. No entanto, diante das ansiedades surgidas e de um não-investimento do professor (o fundador!), o grupo não consegue elaborar os sentimentos que bloqueiam a entrada na tarefa e então, muda seu foco, deixando de lado o objetivo e entrando numa situação de manutenção do espaço conjunto. Neste momento o grupo deixa de ser um grupo operativo. 


\section{Capítulo 6}

\section{O Último ANo}

Em 2006, na quinta edição do projeto, novamente Emanuel ministrou aulas para o terceiro ano do Ensino Médio, e a monitoria aconteceu nessa série. Este foi o último ano da monitoria nessa instituição, pois no final de 2006 o professor mudou de escola, e os eventos dessa edição foram cruciais para nossa interpretação a respeito da evolução do projeto.

\section{Promessas de MUdAnÇa}

Após o encerramento das atividades de monitoria em 2005, tivemos uma longa conversa (informal, não como entrevista) com o professor sobre tudo o que havia acontecido naquele ano, sobre as impressões que tivemos e o que realmente aconteceu. Emanuel nos confirmou que não havia se dedicado à monitoria por falta de tempo - já que assumira outros compromissos - e também por conta de seu desânimo com o ambiente daquela escola. Foi consenso entre nós que naquele ano os monitores atuaram muito mais como "ajudantes do professor" do que como "ajudantes dos alunos", e que as reuniões pouco contribuíram para prepará-los para o seu contato com os demais alunos, tornando-se um espaço em que os monitores auxiliavam o professor a tomar suas decisões para a sala de aula e conversavam sobre a vida pessoal.

Feito o balanço de 2005, resolvemos tentar uma nova experiência em 2006. Emanuel continuaria ministrando aulas naquela mesma escola e já estava decidido a montar um grupo de monitoria com seus novos alunos do $3^{\circ}$ ano. Novamente, nós acompanharíamos a experiência, fazendo a coleta de dados como no ano anterior, por meio de gravações em vídeo, entrevistas e diário de campo. Porém, concordamos que desta vez seríamos colaboradores no planejamento da monitoria, ajudando a propor atividades e a acompanhar o trabalho dos monitores, sempre pensando em utilizar o espaço da reunião também para prepará-los melhor para suas funções com os outros alunos. Emanuel nos disse que sua expectativa para 2006 era evoluir com relação ao ano anterior; sua intenção era que os monitores ajudassem mais em sala de aula, pois em 2005 sua atuação junto aos alunos foi bastante pequena.

Esta conversa foi muito interessante e animadora para os dois lados. Para Emanuel porque teria mais uma pessoa junto com ele pensando a monitoria e 
coordenando as atividades. Para a pesquisa que fazíamos, porque teríamos a oportunidade de acompanhar o trabalho por mais um ano, numa perspectiva diferente da anterior, já que dessa vez haveria mais investimento e planejamento para o projeto.

\section{A FORMAÇÃO DO GRUPO E O INÍCIO DA PESQUISA}

A dificuldade de comunicação com Emanuel ficou evidente logo no início do ano. $\mathrm{O}$ combinado era que ele nos procurasse às vésperas do início do projeto para que juntos planejássemos ações para a monitoria. No entanto, o contato não ocorreu e, imaginando que a monitoria já teria começado, procuramos Emanuel, mas ele demorou a responder aos e-mails.

Quando o contato foi finalmente estabelecido, de fato a monitoria havia começado há mais de um mês. Emanuel argumentou que estava muito atarefado e esqueceu de nos avisar sobre o início do projeto. Dessa forma, não acompanhamos a seleção de monitores e a formação do grupo deste ano.

Pelas breves conversas que tivemos e pelo que disseram os monitores nas entrevistas, percebemos que a seleção foi feita nos mesmos moldes do ano anterior com indicação dos colegas e o critério de boas notas em Física - e que foram convidados dois alunos por turma para a monitoria. Assim como ocorreu no ano anterior, os alunos estavam comprometidos com os estudos para o vestibular e muitos não aceitaram o convite de Emanuel. Inicialmente, dez monitores integravam a equipe de 2006: Breno, Bárbara, Aline, Marina, Nelissa, Daniela, Mayara, Iago, Flavia e Michele. No segundo semestre Nelissa e Daniela se afastaram devido ao cursinho, mas Tamiris e Carine entraram para a equipe.

Os alunos deste ano já haviam tido aulas com Emanuel em 2004, quando estavam no primeiro ano. Mas, diferente do que ocorreu em 2005, apenas duas das monitoras deste ano já haviam participado do projeto em 2004: as irmãs gêmeas Bárbara e Aline. Todos os outros estavam estreando na monitoria - embora já conhecessem o projeto muito bem.

Logo após a primeira conversa com o professor, passamos a freqüentar a reunião semanal fazendo anotações no diário de campo. Emanuel pediu que só começássemos a filmar no segundo semestre, alegando que aquele período ainda era muito instável para o grupo, pois os monitores ainda estavam se conhecendo e ele temia que qualquer interferência nossa pudesse "espantá-los" da participação no projeto. 
Embora as reuniões de monitoria tenham sido retomadas no início de agosto, as filmagens só começaram em setembro, pois precisávamos que Emanuel levasse a câmera até a escola e demorou até que ele tivesse tempo de ir buscá-la. Assim, acompanhamos 11 encontros ao longo do ano, sendo que 6 foram filmados e de 5 temos apenas as anotações do diário de campo.

Os planos de trabalho conjunto não se concretizaram. Depois da conversa em que combinamos marcar reuniões para planejar a monitoria, nos desencontramos totalmente com relação a horários. Emanuel assumiu, novamente diversos compromissos profissionais em 2006, e não tinha tempo para marcar reuniões para discutirmos a monitoria. Sem a reunião com o professor para saber o que estava acontecendo com o curso em sala de aula (já que não acompanhávamos esses momentos) ficava difícil planejar atividades que pudessem ser desenvolvidas durante a reunião. Em nossa visão, as tarefas a serem propostas para a monitoria deveriam estar diretamente relacionadas ao conteúdo trabalhado em sala de aula e às necessidades dos alunos. Apenas o professor poderia nos fornecer essas informações, portanto, sem a sua ajuda nos vimos impossibilitados de propor atividades diferenciadas para os monitores e nos limitamos a acompanhar as reuniões como observadores participantes (da maneira como havia acontecido no ano anterior).

\section{OS EVENTOS}

A dinâmica das reuniões de 2006 era muito parecida com a de 2005 e, por esse motivo, vamos narrar os eventos de forma mais sucinta, marcando as semelhanças e diferenças com o processo observado na edição anterior.

Assim como nos anos anteriores, as principais atribuições dos monitores eram o atendimento aos alunos com dificuldade a qualquer momento, o encaminhamento de plantões de dúvidas e o comparecimento às reuniões semanais.

Nesse ano os plantões de dúvidas chamaram a atenção por terem sido muito bem sucedidos. Eles foram mais bem organizados que na edição anterior, pois desta vez o professor marcava todos os plantões do mês e já designava quais monitores seriam responsáveis por cada um. Ao contrário do ano anterior, os monitores desta edição sempre se voluntariavam para encaminhar os plantões e nunca aconteceu de não haver alguém disponível. Sempre que Emanuel pedia, os monitores relatavam o seu bom 
andamento e muitas vezes contavam que tinham resolvido vários exercícios com os alunos e que até chegaram a passar do horário de término do plantão.

Em algumas reuniões Emanuel elogiou os monitores por seu desempenho nessa atribuição. Em geral o professor não estava presente, mas muitas vezes, ao ficar na escola, verificava o andamento do plantão, constatando que eles estavam dominando muito bem aquele espaço: conseguiam controlar bem o grupo de alunos que aparecia e desenvolviam o conteúdo com segurança.

O envolvimento deles era tal que no segundo semestre os monitores idealizaram um novo esquema de trabalho, e o implantaram. Eles decidiram trabalhar de forma parecida com o que eram os antigos grupos de estudo: não mais ministravam uma aula de exercício, como vinha acontecendo em todas as edições do projeto, mas passaram a dividir os alunos em grupos e a trabalhar em conjunto com eles. Esse novo esquema foi elogiado pelos alunos e o professor chegou a sugerir que eles sempre trabalhassem dessa forma dali para frente.

O que funcionou de fato foi o plantão de dúvidas... onde a gente ajudava os alunos com dificuldades a resolver os exercícios...

Iago

Outra atribuição muito forte, principalmente no início, foi a correção de lista de exercícios. Também ao contrário do ano anterior, nesta edição os monitores não se importaram, em nenhum momento durante o ano, em corrigir as listas quando o professor solicitava.

Assuntos relacionados à matéria de sala de aula foram discutidos poucas vezes e, quando isso aconteceu, foi o professor que propôs algum desafio, pedindo que eles resolvessem um exercício da lista que seria foco de estudo no plantão da semana. Em uma ocasião, o professor, após a discussão de um dos exercícios da lista, pediu aos monitores que propusessem modificações (transformando-o em um exercício diferente) e resolvessem. Todos concordaram, e na reunião seguinte alguns apresentaram seus exercícios e discutiram as soluções. Essa era outra diferença significativa desse grupo: eles pareciam sempre dispostos a encarar as atividades propostas pelo professor, mesmo que isso demandasse trabalho extra deles.

É interessante notar que muitas das atribuições dos anos anteriores não estavam presentes nesta edição. Não se falou em tutoria, nem em grupos de estudo, nem em atuação dos monitores na recuperação paralela. Aparentemente as atividades que os antigos monitores mais criticavam foram excluídas dessa edição. Ao menos nas 
reuniões acompanhadas, nunca foi discutida a possibilidade de elas figurarem em 2006 (mas não há como ter certeza se isso não chegou a acontecer no período em que ainda não acompanhávamos o grupo).

Por outro lado, talvez devido à conversa que tivemos no final do ano anterior, o professor parecia estar realmente mais preocupado em inserir atribuições mais relacionadas à atuação dos monitores em sala de aula.

Logo no início de nossas observações os monitores já haviam recebido uma tarefa: em grupos, deveriam construir um telégrafo, de acordo com um pequeno roteiro entregue pelo professor. Na primeira reunião que acompanhamos, no início de junho, alguns monitores levaram o que conseguiram construir. Ninguém conseguiu fazer o experimento funcionar, mas relataram ao professor várias tentativas, mudando materiais e procurando peças alternativas àquelas indicadas no roteiro. Esses monitores tinham muita iniciativa, não se limitando ao roteiro que tinham em mãos. Cabe destacar que o professor pediu que eles montassem o experimento, mas ainda não sabia para que iria utilizá-lo. Pelo seu relato percebemos que ele gostaria de construir o telégrafo com os outros alunos e pensava em uma possível atuação dos monitores, mas não tinha idéia de como iria trabalhar.

Os monitores realmente não conseguiram que o telégrafo funcionasse, e o professor também nunca havia construído um e não sabia o que estava errado. Diante disso, essa atividade foi abandonada e não se falou mais sobre o assunto.

Aí ele passou um trabalho... aí eu não entendi direito o que ia acontecer... eu fiz o trabalho... que foi o trabalho do telefone... que não foi adiante, não teve nada a ver com a monitoria...

Outra tentativa do professor para uma maior atuação dos monitores foi a atividade de construção do capacitor. Da mesma forma como havia ocorrido no ano anterior, Emanuel levou para a reunião o material necessário para construir um pequeno capacitor e pediu que os monitores realizassem o experimento. Durante a construção ele aproveitou para instigar uma discussão sobre os conceitos físicos envolvidos e como o pequeno capacitor funcionava. Todos se envolveram muito nessa discussão levantando hipóteses e relacionando com o que haviam aprendido em sala de aula.

No entanto, o professor também não sabia ainda como seria a atuação dos monitores durante essa atividade quando ela fosse realizada em aula. Sua sugestão inicial foi de que eles dessem uma aula sobre capacitores, o que os assustou um pouco. 
$\mathrm{Na}$ reunião seguinte, Emanuel falou novamente sobre os capacitores e pediu sugestões dos monitores sobre como poderia ser sua atuação para tornar aquela atividade interessante. Eles iniciaram uma boa discussão sobre a viabilidade do desenvolvimento daquela atividade dentro de sala de aula, desde o problema de tempo (quantas aulas seriam necessárias para a construção do capacitor) até a utilidade de os alunos fazerem um experimento sem saber exatamente o que está acontecendo (pois ainda não tinham tido aula sobre capacitor). Em seguida, Emanuel propôs que os alunos realizassem o experimento em duplas e que os monitores circulassem pela sala, dando orientações sobre a construção e sobre a explicação do fenômeno, para que na aula seguinte o professor explicasse a teoria.

Na semana seguinte, durante a reunião e após a realização da atividade em sala de aula, Iago questionou o professor a respeito do papel deles durante a aula de capacitor, pois eles acabaram não atuando da maneira como havia sido combinado e ficaram limitados a acompanhar a construção do capacitor. Emanuel disse que eles foram um apoio e mudou de assunto, mas Iago voltou a insistir que queria que ele deixasse claro qual era o papel deles durante as aulas, pois o professor havia dito que os monitores iriam explicar o capacitor, e no fim ele mesmo explicou, deixando-os quase sem função. O professor entendeu que Iago estava cobrando um protagonismo maior para os monitores, mas confessou que também estava perdido, sem saber como coordenar.

Bárbara: É, na verdade ele queria que a gente ajudasse explicando a matéria, mas aí ficou meio corrido e não deu, e a gente ficou ajudando mais na parte da montagem... que tinha gente que tava com dificuldade de montar aí a gente ajudava: "não é assim que faz, é assim desse jeito e tal..." mas aí acontece né, a gente ajudou mais na parte prática. Na teoria ele explicou tudo.

Pesquisadora: E você acha que foi importante essa ajuda que vocês deram?

Bárbara: Na verdade nem tanto assim, acho que era uma coisa que dava pra ter feito tranqüilo sozinho, assim, o professor sem ajuda dos monitores.

E por fim, uma outra atividade em que Emanuel pretendia aproveitar a ajuda dos monitores era na construção de um rádio-galena, que aconteceria durante as aulas com os alunos divididos em grupos. Emanuel abordou esse tema em várias reuniões. Normalmente o professor se valia de grandes monólogos explicando o funcionamento do rádio e como seria feita a montagem, enquanto os monitores ficavam em silêncio 
prestando atenção nele. Nas duas últimas reuniões antes da montagem do rádio em aula, Emanuel explicou como seria a atuação dos monitores. Basicamente, eles teriam que ajudar desenrolando o carretel de fio da maneira adequada e resolvendo problemas que o grupo pudesse ter durante a montagem, já que eles haviam tido verdadeiras "aulas" sobre o rádio-galena durante as reuniões (Emanuel já havia explicado como seria a montagem, tinha levado um rádio pronto para eles verem como ficaria, e tinha antecipado alguns problemas que poderiam ocorrer e como os monitores poderiam resolvê-los caso o rádio não funcionasse).

Durante a reunião eles comentaram que sua atuação nessa atividade foi bem mais tranquiila do que eles haviam imaginado, pois precisaram apenas ajudar a desenrolar o fio e, como já sabiam construir, a equipe deles acabou fazendo tudo muito mais rápido. Não acompanhamos a aula do rádio, mas pelo relato dos monitores percebemos que novamente sua atuação foi mínima e muito menor do que o prometido pelo professor nas reuniões anteriores. Eles pouco auxiliaram os alunos da classe, tendo uma atuação mais significativa apenas dentro de seus próprios grupos.

Pesquisadora: E na atividade do rádio, a atuação dos monitores foi importante?

Aline: Foi mais ou menos... foi mais na hora de ajudar assim... ai, não lembro agora... Eu lembro que a gente montou... mas como eu e a Bárbara, a gente estava no mesmo grupo, a gente ficava mais no nosso grupo mesmo, então acho que não foi tão importante assim.

Pesquisadora: O que vocês poderiam ter feito para ajudar mais?

Aline: Ajudar na montagem, mas todo mundo já sabia montar, então não tinha muito o que fazer. O professor já tinha explicado tudo, todo mundo já sabia, acho que não tinham muitas dúvidas.

Foi uma coisa muito simples, porque ele [Emanuel] estava lá, e a gente só ajudou a galera a enrolar os fios de cobre lá. [...] Eu acho até que qualquer um dos alunos que tivesse um pouquinho mais de instrução faria aquilo que a gente fez. Eu acho que foi nada... foi só uma mãozinha.

Mayara

A ajuda ao professor, que tinha se tornado um investimento muito grande do grupo anterior, nesse ano não teve tanta força. Emanuel algumas vezes pediu a ajuda dos monitores, perguntando sobre o andamento do curso e sobre o que estava acontecendo com alguns alunos que tinham notas baixas. Em outros momentos foram os 
monitores que se manifestaram comentando suas dificuldades em provas, argumentando que o professor pedia uma quantidade de matéria muito grande e por isso os alunos não se saíam bem, relatando as reclamações a respeito dos trabalhos escolares passados por Emanuel e outros assuntos sempre relacionados ao desempenho dos alunos na disciplina. Percebemos, então, que mesmo que os momentos de ajuda ao professor tenham ocorrido, eles tiveram um caráter diferente daquele do ano anterior. Enquanto em 2005 as ajudas eram muito mais ligadas ao planejamento do professor, a prazos e formato de atividades, neste ano os monitores ajudaram trazendo para o professor principalmente os problemas dos alunos e os aspectos do curso de Física que estavam prejudicando o desempenho deles.

A questão da ajuda com o trabalho trimestral já era, aparentemente, considerada pelo professor como parte das funções dos monitores. Neste ano, novamente, o trabalho seria gravar um programa de rádio, mas o tema ainda não estava definido. Em várias reuniões Emanuel abordou esse assunto, pedindo que os monitores sugerissem como ele poderia avaliar os trabalhos, e também que eles pensassem em temas que fossem interessantes para serem trabalhados no programa. Em uma das reuniões, inclusive, o professor levou os programas de rádio produzidos no ano anterior para que eles escutassem e discutissem o que deu certo e o que não deu, para melhorar a proposta de 2006. Sempre que requisitados a discutir esse assunto os monitores se empenhavam e davam boas sugestões, que pudessem satisfazer as necessidades do professor e também dos alunos.

Essas foram as principais atribuições dos monitores em 2006. É fácil perceber que não houve qualquer nova atribuição neste ano. Pelo que acompanhamos, desde 2002 a cada novo ano sempre existia uma novidade; Emanuel sempre estava preocupado em inserir alguma nova função para os monitores que enriquecesse a monitoria. Em 2006 não só não houve nenhuma novidade, como muitas das atribuições já consagradas na monitoria desapareceram (caso da tutoria e da recuperação paralela, por exemplo). Por outro lado, não é possível ignorar a clara intenção do professor de que os alunos atuassem mais em sala de aula, mas foi nítido que mais uma vez não houve planejamento para as reuniões e para os trabalhos do grupo. Tal fato acabou resultando em informações desencontradas e preparação dos monitores para atuações que nunca aconteceram.

Ainda, uma importante diferença com relação ao ano anterior é a respeito da postura dos monitores dentro das reuniões. Diferente do que observamos em 2005, os 
novos monitores pouco reclamavam. Quando havia reclamações, geralmente eram a respeito de assuntos de sala de aula e muitas vezes os monitores estavam reportando incômodos relatados pelos alunos. Quase não se viu os monitores reclamarem de qualquer de suas atribuições ou qualquer atividade que Emanuel propusesse a eles (os momentos em que isso aconteceu foram protagonizados por Iago e vamos discuti-los na próxima seção).

Também ao contrário do que observamos no ano anterior, este novo grupo costumava se empenhar no que dizia respeito à ajuda aos alunos e trazia muitas boas sugestões para melhorar a monitoria. Como exemplo, citamos o novo esquema de plantões de dúvidas criado e colocado em prática por eles. Também em alguns momentos eles sugeriram que poderiam dar seminários para os outros alunos, pois acreditavam que eles prestam mais atenção quando a aula é dada por alunos. Neste caso em especial, Emanuel não gostou da idéia, por temer que estivesse delegando aos monitores funções que deveriam ser dele próprio mas, por fim, acabou aceitando a sugestão dos seminários. Essa postura é interessante porque não observamos atitudes como esta no grupo anterior, parecendo que em 2006 os monitores estavam preocupados em desempenhar funções junto aos alunos e criar condições mais favoráveis para seu aprendizado.

O mais importante [da monitoria] são os plantões que você marca e o pessoal vem. Já vem preparado assim, o que a gente vai dar, os conteúdos... e ajuda pra caramba. Muita gente já veio me procurar falando que gostou, que aprendeu bastante e tal, foi melhor na prova... eu acho mais legal isso, a gente ajuda direto.

Bárbara

Fica claro também que eles consideravam que sua principal função era ajudar os colegas, diferentemente da edição anterior, quando os monitores indicavam que ajudar o professor era atribuição até mais importante que ajudar os alunos.

Pesquisadora: E a função dos monitores é só de ajudar ou vocês tem alguma outra função fora essa?

Bárbara: É, às vezes o professor está dando alguma aula... às vezes ele chama o monitor pra dar essa aula entendeu? Mas é só isso, ajudar os alunos que tem dificuldade.

Percebemos que a dinâmica de trabalho deste grupo tem diferenças significativas em comparação com a do ano anterior. Primeiramente podemos destacar a modalidade 
de interação de seus membros. Durante as discussões, fossem relacionadas às suas funções como monitores ou à ajuda ao professor, todos opinavam, davam sugestões e trabalhavam em conjunto para resolver o problema surgido. A modalidade de interação predominante era de todos com todos, com raros momentos de interação dual. As intervenções de cada um na discussão sempre eram no sentido de agregar, de contribuir, discordando, concordando ou propondo novas soluções. Diferente do observado em 2005, não existia diferença de modalidade de interação conforme o tipo de tarefa abordada (ajudar os alunos ou o professor).

Outra importante diferença se refere ao teor das discussões surgidas durante as reuniões. Neste ano elas eram muito mais centradas no trabalho da monitoria que se relacionava à ajuda aos alunos. As conversas pessoais foram raras, e não houve momentos de descontração como festas de aniversário (exceto na última reunião do ano, na qual o professor organizou um lanche para comemorar o encerramento das atividades da monitoria e fazer a entrega dos certificados de participação). Este ponto é evidenciado nas entrevistas, quando pedimos aos monitores que nos contassem o que ocorria durante as reuniões semanais. Enquanto no ano anterior as respostas enfatizavam o caráter "descontraído" das reuniões, a abertura para poder conversar sobre "qualquer assunto", para reclamar e opinar no curso de Física e ficar sabendo com antecedência sobre as atividades, em 2006 os monitores focaram suas respostas na importância da reunião para organizar o trabalho que seria realizado com os outros alunos.

A reunião serve pra gente... depende, cada dia a gente fala uma coisa: um dia a gente fala como está indo o andamento, como está funcionando. Aí a gente marca os plantões, quando vão ser; a gente agenda tudo; a gente fala sobre a matéria que está por vir; os trabalhos que estão por vir; qual vai ser nossa função quanto a isso; o que que a gente vai dar de matéria...

Bárbara

[Nas reuniões] A gente discute mais em geral, como a galera está indo nas provas, o andamento dos trabalhos. [...] A gente precisa de um rumo pra seguir. Ele é o professor e ele tem que falar pra gente o que a gente tem que fazer ou às vezes um caso específico dizer que você tem que dar mais atenção pra tal aluno. [...] É uma direção, né.

Mayara

Ainda através das entrevistas, percebemos que os monitores se sentem valorizados pela confiança depositada neles por Emanuel. É um fator bastante importante para eles saber que, ao convocá-los para o projeto, o professor confiou essa 
tarefa a eles, e não a outros alunos. Mayara comenta que outros professores, que também desenvolviam projetos de monitoria na escola, pediam voluntários para se tornarem monitores, mas para ela o processo era diferente, pois o professor não estava depositando confiança nela, mas sim em qualquer aluno que quisesse participar.

O professor de química tentou fazer [uma monitoria], mas foi um fracasso. Porque ele não convocou os alunos como o Emanuel faz [...], o professor de química falou "qualquer um que quiser ser monitor pode chegar." [...] A gente gosta muito do Emanuel porque ele está confiando na gente. Nenhum outro professor faz isso. $O$ de química tentou, mas não é que ele confiou em você, ele confiou em todos.

Mayara

Eu continuo porque, além de me ajudar, é aquela coisa de você ficar satisfeito por saber que o professor confia em você [...] e querendo ou não ajuda alguns alunos que procuram às vezes.

Carine

O professor, por outro lado, também teve uma postura diferente com este grupo. Sua preocupação em utilizar os monitores em mais situações de interação com os outros alunos foi bem maior, mas ainda assim ele não conseguiu cumprir seu objetivo. Logo no início das atividades da monitoria ele comentou, durante uma reunião, que gostaria de aproveitar mais os monitores, ainda que não soubesse exatamente como faria isso. Apesar dessa intenção, as atividades criadas por ele com essa finalidade acabaram não tendo continuidade, sendo abandonadas antes de sua realização ou resultando numa participação quase nula dos monitores. Enquanto no ano anterior os monitores nunca fizeram qualquer tipo de crítica à monitoria, ou mais especificamente à eficiência de seu trabalho com os alunos, em 2006 o monitor Iago foi protagonista de uma série de críticas e questionamentos sobre a utilidade da monitoria nos moldes em que vinha sendo desenvolvida.

\section{IAGO: O PORTA-VOZ}

Iago chamou nossa atenção logo nas primeiras reuniões que acompanhamos por contestar Emanuel com frequiência. Ele questionava atitudes do professor dentro de sala de aula e também muitas das atribuições propostas aos monitores e os resultados obtidos por meio delas. Podemos separar as críticas de Iago naquelas dirigidas ao professor e aquelas dirigidas ao coordenador da monitoria, sendo que essa separação se justifica principalmente quando analisamos as reações dos outros monitores. 
Com relação às críticas ao professor, com freqüencia Iago aproveitava o espaço da reunião para falar sobre métodos utilizados por Emanuel para ensinar e com os quais ele não concordava. Por exemplo, ele reclamava do uso de transparências, criticava o fato do professor proibir o uso de calculadora, as brincadeiras feitas por ele durante as aulas e também algumas atividades, como a auto-avaliação. Já desde o ano anterior percebemos manifestações como essa por parte dos monitores, mas Iago se destacou pelos bons argumentos que apresentava e por sua postura firme e algumas vezes até um pouco agressiva com o professor. Quando Iago fazia esse tipo de crítica era constantemente apoiado pelos outros monitores.

Por outro lado, se destacaram ainda mais as críticas que ele fez à monitoria e eficiência do projeto. Nunca antes presenciamos um monitor fazer qualquer crítica, por menor que fosse, aos moldes da monitoria, mas Iago fazia isso constantemente e diretamente, sem meias palavras. Nessas situações os monitores se posicionavam contra ele, dizendo que ele já nasceu reclamando e que era muito estressado.

Ainda no primeiro semestre, Emanuel perguntou aos monitores, durante a reunião, como estava a monitoria e, enquanto os outros disseram que tudo ia bem, Iago reclamou que o professor tinha dito que eles iriam fazer várias coisas e que seria uma ótima experiência, mas eles apenas tinham dado plantões até aquele momento.

Iago costumava reivindicar um protagonismo maior dos monitores, que eles fizessem mais do que "apenas" dar plantões, e principalmente cobrava de Emanuel que cumprisse aquilo que prometia aos monitores em termos de oportunidades de atuação. Comentamos anteriormente sobre a atividade do telégrafo que foi proposta aos monitores no início do ano e que sumiu sem qualquer satisfação. Apenas Iago cobrou o sumiço dessa atividade, arrancando do professor uma confissão de que ele não sabia como proceder com relação a isso.

$\mathrm{Na}$ atividade do capacitor, Iago também foi o único que questionou a pequena atuação dos monitores. Embora os outros, em entrevista, também tenham dito que sua atuação nessa atividade foi pequena, Iago foi quem levantou questionamentos e perguntou o que Emanuel queria deles, considerando que ele costumava pedir que os monitores atuassem em determinadas atividades, preparava-os durante as reuniões, mas quando chegava na hora da aula, ele não os aproveitava.

[...] e aí teve os plantões que funcionaram até relativamente bem, e aí a princípio foi isso. A gente ajudou no rádio... que foi o único projeto dos dez 
que teve que a gente ajudou... nos outros projetos a gente não teve função nenhuma.

[...] a estrutura eu acho que... a base da estrutura está boa, entendeu? Mas o dinamismo dela poderia ser maior. Como eu falei, o projeto que a gente não levou adiante, pouca utilização dos monitores e tal.

Iago

Outro foco de críticas de Iago era com relação aos resultados obtidos pelos alunos com a existência da monitoria. Em uma das reuniões, Iago perguntou ao professor sobre o resultado das provas depois da monitoria e, quando Emanuel disse que a média das turmas tinha sido 2,5, ele criticou a eficácia dos plantões, pois se estes estivessem funcionando as notas dos alunos deveriam ser melhores.

Em outros momentos Iago fez críticas como essa, se referindo às constantes notas baixas dos alunos de todas as turmas (inclusive daqueles que freqüentavam os plantões), porém Emanuel respondia que o objetivo da monitoria era desmobilizar os alunos de um discurso de "não tive oportunidade". Mesmo assim, Iago insistia nesse ponto como sendo o principal termômetro de que a monitoria não ia bem. Sempre que isso acontecia, os outros monitores se posicionavam contra ele e diziam que, se pelo menos um aluno melhorou de nota, então o trabalho deles já tinha valido a pena.

Em uma das reuniões do mês de outubro, Emanuel resolveu conversar com os monitores e avisá-los que em breve eles seriam entrevistados para falar sobre a monitoria. Diante desse assunto Iago disse que achava a monitoria inútil. Todos ficaram perplexos diante dessa afirmação e logo se posicionaram contra Iago como podemos observar na transcrição do diálogo que se seguiu:

Iago: Eu acho inútil.

Flávia: Meu Deus cara, como você é estressado!

Iago: (fala calmamente) Eu estou estressado? Não. Foi um comentário, é algo inútil... é algo inútil... você está vendo alguém melhorar de nota, progressão do grupo?

Marina, Flávia e Bárbara: Eu.

Iago: Tá, fora os monitores. O grupo, alguém está progredindo? Não está.

Flávia: Você é muito pessimista.

Iago: Pessimista não, realista. Eu cheguei das férias e estava lá a tabela grudada na parede: 1,$0 ; 2,0 ; 0 ; 1,0 ; 2,0 ; 2,0 ; 3,0 .$. Não é pessimismo, estava lá na parede. 
Emanuel: Então por que você fica? Por que veio? Com o que sonhava?

Iago: Eu não sonhava nada, você me convocou. Eu falei "posso não ir?", e você falou "você vai!".

Emanuel: Eu falei “vai ver como é, depois não vai se não quiser”. Aí eu ofereci uma bolacha recheada e você...

Iago: Olha, a gente come, a gente ganha meio ponto, todo o trabalho já está meio que feito quando a gente vai fazer...

Flávia: Mais ou menos, né. Porque a gente ganha, mas tem que explicar, tem que agüentar gente que fala mal.

Bárbara: E se você ver, não é o grupo, você vê que tem pessoas que aproveitam. Você não quer também fazer milagre e fazer de repente 150 pessoas entenderem Física, mas se na sua classe tem pelo menos duas que progrediram já está valendo a pena.

Iago: Na minha classe ninguém progrediu.

Na seqüência da conversa Emanuel explica que em sua visão o importante é que a oportunidade seja oferecida ao aluno.

$\mathrm{Na}$ reunião seguinte, em que Iago não estava presente, Emanuel resolveu novamente conversar com os monitores e iniciou perguntando se eles não se sentiam subutilizados na monitoria. Essa pergunta do professor, uma semana após a crítica de Iago e quando esse monitor não estava presente, demonstra que ele também estava incomodado por não continuar inovando nas funções dos monitores e por acabar apenas mantendo o espaço da monitoria com um mínimo de atribuições. Os monitores disseram que não se sentiam subutilizados, que estavam acostumados com esse modelo de monitoria e não sabiam como poderia ser diferente.

Em entrevista, perguntamos a Iago sobre sua afirmação de que a monitoria era inútil.

Iago: É bem pouco útil eu acho, porque não tem muita utilidade... a maioria dos projetos que a gente tentou levar a frente não deu certo. A gente passava assim um mês, um mês e meio tentando produzir... no começo a gente tentou um mês e meio produzir acho que era um telégrafo e um telefone, o telefone ninguém conseguiu produzir e o telégrafo um grupo conseguiu... as gêmas conseguiram fazer o telégrafo e o Emanuel mostrou, fechou ali na monitoria e acabou, entendeu? Não foi levado pra sala e ninguém continuou... então a monitoria... tipo... o que eu vejo... foram os plantões... teve o trabalho do rádio também que a gente ajudou pouco também e teve uma aula que a gente deu sobre... não lembro o que que era a aula... era ah! Campo magnético dos elétrons. Então são três focos ao longo de seis meses de 
trabalho. Acho que é uma produtividade baixa, então inútil eu falo que não é, mas bem pouco produtivo eu achei.

Pesquisadora: O que é ser produtivo?

Iago: Ah, a produtividade vai muito do resultado, entendeu? Essas poucas coisas que a gente fez se tivesse tido um grande efeito aí você vai e fala "pô produziu alguma coisa concreta”, agora, muitas vezes depois das monitorias e tal você pega a folha de notas, de zero a cinco, aí duas ou três notas só ficaram acima, bem acima da média... então, sei lá, pelo menos na minha sala, nas últimas provas finais ficaram três, quatro notas acima da média... numa sala de vinte e três alunos é uma coisa que... se vocêfor ver não surtiu muito efeito. Então a produtividade vai muito do resultado e o resultado eu achei que foi baixo. Então se a gente tivesse feito pouca coisa, mas tivesse tido resultado aí eu diria que foi produtivo[...]

Diferente do que observamos no ano anterior, em 2006 havia um monitor que trazia à tona uma série de questões a respeito dos moldes e resultados alcançados pela monitoria. Iago enuncia um conteúdo que é do grupo: "as necessidades dos alunos não estão sendo supridas e os monitores poderiam atuar mais" e, portanto, assume o papel de porta-voz, que denuncia um conteúdo latente no grupo.

O grupo de monitores formado em 2006 também percebe as vantagens que o projeto lhes proporciona (ganho de nota, possibilidade de opinar na disciplina, proximidade com o professor), mas ao mesmo tempo é mais centrado nas questões que se relacionam com a ajuda aos colegas - estão sempre dispostos a novas atribuições, fazem sugestões de melhorias para a monitoria. Assim, embora percebam vantagens em permanecer juntos, sua tarefa é "ajudar os alunos". Um exemplo deste interesse em oferecer oportunidades aos colegas aconteceu em uma reunião em que Emanuel disse aos monitores que eles deveriam deixar os alunos "vagabundos" de lado e se concentrar apenas naqueles que realmente tinham dificuldade. Iago discordou do professor, argumentando que dessa forma eles estariam fechando as portas para alguns alunos, o que não seria justo, pois a monitoria deveria ser para todos. Os outros monitores apoiaram Iago e também disseram ao professor que não gostariam de atuar daquela forma porque não achavam justo.

Existe uma insatisfação pelo fato de o projeto de monitoria não estar dando conta de suprir as necessidades dos alunos que permanecem com notas muito baixas. Angustiados com a falta de resultados nas notas dos alunos e com sua pequena atuação, os monitores depositam esses sentimentos em Iago. Como depositário das ansiedades e 
necessidades do grupo, ele assume o papel de porta-voz e enuncia o conteúdo latente do grupo.

Segundo Pichon-Rivière (1994, p. 128):

o porta-voz de um grupo é o membro que em um momento denuncia o acontecer grupal, $[. .$.$] as ansiedades e necessidades do grupo. Mas o$ porta-voz não fala só por si, mas por todos; nele se conjugam o que chamamos de verticalidade e horizontalidade grupal, entendendo-se por verticalidade aquilo que se refere à história pessoal do sujeito, e por horizontalidade o processo atual que acontece no aqui-agora do grupo, na totalidade dos membros.

As necessidades e ansiedades enunciadas pelo porta-voz e a maneira como ele as formula estão relacionadas à sua história pessoal, enquanto que o fato de enunciá-las em um determinado momento está relacionado ao momento vivido pelo grupo.

No caso de Iago, o conteúdo trazido à tona, embora compartilhado por todos os membros, carrega uma ameaça à grupalidade: se a monitoria não é útil então ela pode acabar e o grupo se desfaz. Por medo da "morte", o grupo não reconhece o enunciado e se defende dizendo que Iago é muito estressado e que se pelo menos um aluno melhora, então tudo valeu a pena (o que garante a manutenção do grupo). Temos indícios de que os enunciados de Iago são compartilhados por todos quando ele faz críticas à monitoria que não ameaçam a existência do grupo (ou seja, quando suas críticas são ao professor e não ao coordenador da monitoria), pois nessas situações ele é apoiado pelos outros monitores. Além disso, quando ele diz que a monitoria é inútil ou reclama sobre a falta de resultados nas notas, os monitores se posicionam contrariamente, mas sem conseguir argumentar contra ele; em geral apenas dizem que Iago já nasceu reclamando ou que ele é muito estressado e depois acrescentam que, se um aluno melhora, então a monitoria se justifica.

O conceito de porta-voz é central na teoria de Pichon-Rivière, pois ele é o depositário das ansiedades, necessidades e fantasias grupais, e quem enuncia (ou denuncia) esses conteúdos. Tal papel é importante porque o coordenador (o terapeuta em grupos de cura e o professor em grupos de aprendizagem) pode interpretar esse enunciado que até então estava implícito, "como que escondido na totalidade do grupo", e com isso pensar em suas intervenções. As críticas de Iago mexem com o professor, que se sente incomodado por subutilizar os monitores. O professor reconhece a mensagem trazida por Iago, no entanto ele também não consegue modificar sua própria 
atuação na monitoria, fazendo com que as angústias e necessidades dos monitores permanecessem em pauta através das falas do porta-voz durante todo o ano.

\section{ESTAGNAÇÃO DO GRUPO E FIM DO PROJETO}

Percebemos que este grupo, diferentemente do grupo de 2005, estava focado em sua tarefa de ajudar os colegas, embora fosse nitidamente bastante dependente do professor. Esses monitores trabalhavam em prol de ajudar, mas só avançavam e inovavam à medida em que eram instigados por ele. Essa é ainda uma diferença em relação aos grupos das primeiras edições da monitoria, pois aqueles eram criativos, resolviam os problemas surgidos e planejavam ações, enquanto estes, apesar de não terem se desviado da tarefa objetiva, faziam o mínimo que era demandado deles. Assim, podemos dizer que o grupo de 2006 atingiu o momento de tarefa, pois ele buscava condições para a realização da tarefa objetiva, mas ainda não ia além, pois não se tornou capaz de planejar ações e traçar objetivos para o futuro (o que caracteriza o momento de projeto).

Algumas considerações importantes devem ser feitas a respeito desse grupo para que possamos entender melhor algumas diferenças na dinâmica de trabalho deste grupo e daquele do ano anterior. Vimos que em 2005 o investimento do professor foi pequeno, pois foi se envolvendo cada vez mais com outros projetos profissionais fora da escola, que demandavam boa parte de seu tempo. Em 2006 isso não foi diferente, os projetos fora da escola tiveram continuidade e pudemos perceber que seu investimento foi tão pequeno quanto no ano anterior.

Por outro lado, não podemos deixar de lembrar que neste ano o professor parecia preocupado em utilizar os monitores em mais situações que no ano anterior. Uma pergunta que pode ser formulada é: por que essa preocupação apareceu e por que o professor não conseguiu colocá-la em prática? Temos como hipótese que a conversa que tivemos no final de 2005 pode ter despertado nele essa preocupação. Muito possivelmente ele já havia percebido sua falta de investimento, mas foi nesta conversa que pela primeira vez houve uma cobrança externa nesse sentido. Ao mesmo tempo, ao longo de todo o ano o professor continuou sendo cobrado por Iago, de forma que a todo momento ele era lembrado de sua falta de investimento e de que daquela forma o projeto idealizado por ele estava em constante declínio. 
Outro ponto importante é com relação aos laços afetivos entre monitores e professor. Esses monitores de 2006 haviam sido alunos de Emanuel anteriormente, mas apenas duas alunas já haviam participado do projeto de monitoria. Vimos que no ano anterior quase todos os membros do grupo já haviam sido monitores antes e, principalmente, haviam participado do projeto em seu auge, em 2003. Percebemos aqui uma importante diferença entre os grupos, pois aqueles de 2005 já chegavam com laços afetivos formados e uma experiência de sucesso juntos, enquanto que os de 2006 estavam começando a construir laços dentro da monitoria naquele ano.

O professor mesmo, em entrevista, nos dá indícios do quão significativa é essa diferença para a dinâmica dos grupos:

"Esse aqui [experiência de 2006], ficou bem abaixo da minha expectativa do que eu creio que pudesse ir [...] Tinha muita coisa que dava pra fazer, mas que na tocada dos trabalhos ficaram por fazer e ficou o trivial que foram os plantões, os grupos de estudo que realmente conseguimos fazer $e$ nas reuniões aquilo que dava pra encaminhar, a gente encaminhava. $O$ gostoso é essa relação que fica, professor-aluno. Essa relação, ela por si só é um grande ganho. [...] Fazendo um balanço de perdas e ganhos, acho que perda não houve, acho que deixou de ganhar, podia ter ganho mais. Mas o ganho mais significativo mesmo, eu acredito ter sido o ganho dessa relação com os monitores. [...]"

"A experiência da monitoria em 2005 foi muito mais legal, até por conta da experiência de 2003 ter sido muito boa. Porque esses alunos que tiveram no ano passado [2005] foram meus monitores em 2003, no primeiro ano. Então era uma continuidade, um estendimento dessa experiência... é muito interessante, era uma novidade a monitoria no terceiro ano, não tinha muito parâmetro [...]"

"[2006] era pra evoluir, a experiência era pra evoluir, agregar do ano passado pra ver o que de novo dá pra ter agora, mas acabou dando manutenção... ficamos com o feijão com arroz lá e não teve muita novidade não."

Emanuel (entrevista no final de 2006)

Percebemos pelas falas de Emanuel que ele não ficou muito satisfeito com a experiência da monitoria em 2005 e tinha expectativas de mudança para 2006, mas que não se concretizaram. Ele admite que não houve novidade com relação a 2005, que as experiências foram equivalentes, porém, mesmo assim, diz que a de 2005 foi boa pelo fato de os monitores terem sido os mesmo que estiveram com ele em 2003, um ano em que o projeto foi muito bem sucedido. 
Vimos que em 2005, pelo fato de a relação estabelecida entre eles ter sido tão boa, o grupo deslocou sua tarefa de ajuda aos colegas para "ficar junto", fazendo da monitoria apenas um pretexto para se manterem próximos. Esse deslocamento foi facilitado pelo professor, que com sua falta de investimento na monitoria causada pela mudança de foco em sua vida profissional, aderiu à mudança de tarefa, não intervindo no grupo de maneira a conduzi-los à operatividade. Já em 2006, como não havia relação pré-estabelecida entre os membros do grupo, o "ficar junto" já não era tão importante e foi aberto um espaço para a crítica ao projeto (trazida à tona pelo porta-voz Iago).

Ainda, percebemos que no final de 2006 Emanuel estava muito insatisfeito com a instituição e reclamando muito de ter que continuar dando aulas lá mais tempo.

Esse ano[2006], quando eu digo que não foi tão bom, não é que não foi bom, foi bom, mas ficou um gosto de quero mais em função da expectativa que acontecia no início do curso. Eu estou de saco cheio daquele colégio e acaba influenciando isso aí. É muito ruim ter que ficar lá mais um ano.

Emanuel

A relação do professor com a instituição e mesmo a relação do projeto de monitoria com a instituição nunca foram nosso foco de pesquisa, portanto não coletamos dados que permitissem investigar esses pontos. No entanto, não pudemos deixar de notar as constantes reclamações de Emanuel a respeito da escola onde trabalhava, chegando a desejar mudar de emprego. De fato, no final de 2006 ele saiu daquela escola, marcando o fim da monitoria naquela instituição.

$\mathrm{Na}$ finalização de nossos trabalhos de análise dos dados nos perguntamos que papel a relação do professor com a instituição poderia ter tido no processo de desenvolvimento da monitoria ao longo dos cinco anos. Dessa forma, enviamos um email a Emanuel pedindo uma nova conversa sobre a monitoria. Como o pedido foi feito às vésperas do Natal e os compromissos dificultavam nosso encontro, decidimos por uma pequena entrevista por e-mail. Nesta, pedimos a Emanuel que nos contasse sobre sua relação com a instituição durante o tempo que esteve envolvido com o projeto de monitoria.

Fica mais fácil falar de como era minha relação com as instâncias de poder na escola, nesta época. Sempre foi bem amistosa e muito aberta quanto a novidades devidamente encabeçadas e totalmente de responsabilidade do professor. Não havia, portanto qualquer cumplicidade, qualquer tipo de apoio por parte da direção caso alguma atividade inovadora proposta desse errado (entenda-se por isso, pais buzinhando na orelha da direção). Este era $o$ principal termômetro que media a "eficiência" de uma proposta 
pedagógica ali. Havia outro aspecto com peso menos proeminente, que denunciava se seu projeto apresentava algum risco ao poder estabelecido. Caso o projeto fosse muito bom, parecia representar um certo risco para a orientadora pedagógica (a 'semi-deusa' logo abaixo da irmã diretora toda-poderosa). Dessa forma, apesar das inúmeras exortações proferidas nas desbussoladas reuniões semanais pedagógicas, para que propuséssemos projetos interdisciplinares e contextualizados, segundo os PCN, a própria direção se incumbia de não proporcionar nenhum espaço ou tempo para que os professores se organizassem para que tais propostas fossem plenamente efetivadas. Sendo assim, minha relação com a direção, nos primeiros anos era de buscar compreender o que se queria com o que era pedido, chegando à conclusão de que poderia ser qualquer coisa mais relacionada à manutenção do status quo local, e muito menos a ver com melhorias pedagógicas que visassem maior eficiência no ensino e no aprendizado. Ao final de minha estadia na escola, minha relação com a direção beirava o cinismo, posto que eu não conseguia fazer de conta que estava tudo bem, tampouco conseguia sentir apoio e estímulo para propor qualquer inovação ou melhoria em nossos trabalhos. Muitos profissionais de excelente qualidade já haviam passado por lá nos anos em que ali atuei, construindo o mesmo discurso e opinião que a minha acerca da direção da escola. Eu usava uma metáfora que explicava bem minha visão: o colégio é uma águia que foi criada como uma galinha.

Emanuel

A resposta de Emanuel confirmou nossas suspeitas de que sua relação com a instituição vinha se deteriorando há algum tempo. Embora não tenhamos investigado este aspecto, nossa vivência dentro da escola confirma que o apoio dado pela instituição ao projeto era apenas "ceder o espaço". Emanuel nunca recebeu qualquer pagamento financeiro em troca de seu trabalho na monitoria, o projeto foi tocado por ele por uma questão de satisfação pessoal, sem que isso trouxesse um ganho material. Ainda, é perceptível que a instituição nunca se envolveu mais profundamente com o projeto. Um exemplo disso é que Emanuel entregava certificados de participação na monitoria para os alunos no final do ano, porém esses certificados eram confeccionados por ele e não tinham valor institucional, pois a escola não oferecia um certificado timbrado aos monitores. Apenas as monitoras conhecidas como "panteras" conseguiram um certificado da escola por sua permanência em três anos do projeto, mas depois de o professor pedir à diretora.

Nós nunca acompanhamos as reuniões pedagógicas e nem procuramos saber detalhes sobre ela, mas temos indícios de que o projeto não era promovido ou mesmo incentivado frente aos outros professores, afinal, embora ele tenha alcançado grande sucesso em seus primeiros anos, não obteve a adesão de mais professores (exceto de biologia, matéria cuja professora mantinha boa relação pessoal com Emanuel). 
A saída de Emanuel da escola claramente está relacionada a um conflito entre professor e instituição que tornou a situação insustentável. O projeto ainda sobreviveu na disciplina de biologia, que embora tivesse um formato bastante diferente da de Física, também estava colhendo bons frutos. No entanto, como nenhum dos outros professores de Física da escola aderiu à monitoria, a saída de Emanuel no final de 2006 marca o fim da trajetória do projeto de monitoria nessa disciplina. 


\section{CONSIDERAÇõES FINAIS}

\section{CONCLUSÕES SOBRE A TRAJETÓRIA DO PROJETO}

A partir de nossa vivência profissional percebemos que um projeto inovador em uma escola freqüentemente nasce apoiado em uma esperança de mudanças no ambiente escolar. Tal mudança pode ser pretendida por diferentes sujeitos (professor, diretor, instituição), em diferentes aspectos (aprendizagem, mudança de atitudes, desenvolvimento de valores). No entanto, essa vontade de provocar uma mudança, embora seja um importante pontapé inicial, não é suficiente para a manutenção do projeto. Emanuel, ao propor a monitoria discente para a escola em que trabalhava, acreditava

[...] na possibilidade de uma mudança na mentalidade discente a partir de um esforço por fazer passar uma oportunidade de experiência. Experiência esta que pretensamente marcaria os sujeitos envolvidos de modo a inserir em seus universos culturais novos elementos que perturbariam uma ilusão estática construída há tempos, expresso num saber ostentado com orgulho e que os alienava. (relato de Emanuel, p. 216).

Apesar de ter conseguido implantar o projeto da maneira como idealizou e de ter como objetivo um contínuo avanço da proposta, Emanuel não conseguiu sustentá-lo por muito tempo, indicando que apenas o esforço do idealizador em busca da mudança não é suficiente para a manutenção de um projeto. Então podemos nos perguntar quais seriam os fatores que influenciaram a trajetória do projeto de monitoria dentro do ambiente escolar.

As narrativas dos capítulos 4, 5 e 6 nos permitiram analisar os diversos grupos que constituíram a monitoria. Perseguindo o objetivo de entender o que levou ao evidente declínio do projeto em seus últimos anos, tentamos identificar as marcas que os diferentes grupos imprimiram ao projeto, ou seja, como as características de cada grupo participante contribuíram para o processo de desenvolvimento da monitoria na instituição.

A teoria desenvolvida por Pichon-Rivière nos auxiliou a entender a relação que cada um desses grupos estabeleceu com a tarefa. Essa relação se revelou um elemento importante para a compreensão da trajetória de ascensão e declínio do projeto de monitoria. Ainda, como elementos importantes desse processo, temos três constantes ao longo dos cinco anos: o professor, a instituição e o formato do projeto. 
Pelo relato do professor (narrativa do capítulo 4) percebemos que as duas primeiras edições da monitoria foram de grande sucesso. Os grupos se implicaram verdadeiramente com a proposta e se engajaram no trabalho de ajudar os colegas. Muitas vezes novas tarefas eram criadas pelos monitores e eles sempre contribuíam com novas idéias para melhorar aquelas propostas pelo professor. Eles eram criativos e enfrentavam os problemas surgidos. Os grupos de 2002 e 2003 conseguiram atingir uma configuração grupal que os levava a caminho do momento de projeto, tendo aprendido a superar as ansiedades básicas e planejar objetivos futuros. Portanto, a trajetória do projeto é ascendente em seus dois primeiros anos, atingindo um grande sucesso em 2003.

Com relação ao grupo de 2004, o relato do professor é bastante sucinto, mas nos indica que ela também havia sido bem-sucedida. $\mathrm{O}$ investimento na monitoria interséries ganhou força naquele ano e pareceu ser o foco de maior investimento do professor. No entanto, não temos um relato completo dos eventos que nos permitam concluir sobre a relação daquele grupo com a tarefa.

Em 2005 (narrativa do capítulo 5), quando começamos a acompanhar as reuniões de monitoria, nos surpreendemos por não encontrar um grupo criativo e engajado na tarefa de ajuda aos colegas. Cursando o terceiro ano do Ensino Médio, a maioria dos monitores já tinha participado da edição de 2003 e por isso já chegaram com identificações construídas e uma história de sucesso no passado.

Apesar da excelente experiência que tinham vivenciado dois anos antes, os monitores pouco se empenharam na tarefa de ajudar os colegas e se mostravam interessados em usufruir alguns benefícios conquistados (nota, poder institucional e perante os colegas) e a relação afetiva que estabeleceram entre si e com o professor. Nitidamente o projeto de monitoria já não era mais o mesmo.

Externamente o projeto parecia continuar funcionando, pois os plantões continuavam acontecendo, existia a tutoria e também as responsabilidades com relação à recuperação paralela, mas internamente o grupo se comportava de maneira diferente. Ele deslocou sua tarefa para "ficar junto", e manter o projeto de monitoria era essencial para a existência do espaço conjunto. Diante dessa situação, não havia espaço para críticas dentro desse grupo e a monitoria foi levada até o fim do ano sem grandes conquistas ou inovações. Percebemos que houve um declínio do projeto em relação ao que já havia sido conquistado. 
Em 2006 (narrativa do capítulo 6), após o balanço da situação do ano anterior, existia uma expectativa de mudança através do envolvimento dos monitores em mais atividades em sala de aula. Apesar dessa expectativa, pouca coisa foi efetivamente feita nesse sentido. O que observamos foi um grupo mais engajado na tarefa de ajudar os colegas, mas que ainda se encontrava bastante dependente do professor, esperando dele as instruções para sua ação. Por não encontrar no professor, seu coordenador, grande investimento na monitoria, o grupo também não investiu grandes esforços e se limitou a fazer o mínimo que lhe foi pedido.

Nesta edição os monitores eram novos no projeto, não havia relação afetiva prévia entre si e com o professor e nem a lembrança de uma experiência de sucesso juntos, o que abriu espaço para que a crítica surgisse através do porta-voz Iago. O professor entendeu a mensagem trazida pelo porta-voz a respeito da subutilização dos monitores e da denúncia sobre seu trabalho não estar suprindo as necessidades dos alunos, no entanto, Emanuel não conseguiu intervir para modificar essa situação. Dessa forma, 2006 foi mais um ano de declínio do projeto.

Através da análise do desenvolvimento de cada grupo que fez parte do projeto conseguimos algumas pistas mais específicas sobre elementos que marcaram o caminho da monitoria. As relações afetivas estabelecidas se mostraram cruciais para o modo de trabalhar dentro do projeto. Nos anos de auge da monitoria (2002 e 2003) foram construídos sólidos laços afetivos entre professor e monitores. As "panteras" foram as pioneiras do projeto e junto com Emanuel enfrentaram os primeiros problemas surgidos pela falta de experiência de todos em um projeto como aquele. Em várias de nossas conversas informais e até durante as entrevistas, Emanuel deixa claro que tem um carinho especial por elas, pela confiança mútua que conquistaram ao desbravar as primeiras trilhas da monitoria.

Em 2003, a experiência adquirida no ano anterior permitiu um ajuste para muitos dos problemas que tinham surgido. Sabendo lidar melhor com alguns percalços inerentes ao projeto, Emanuel pôde dedicar mais esforços às novidades da monitoria, fazendo com que aquele fosse um ano de grande sucesso de seu projeto. Em seu relato, e também em conversas que tivemos com ele e com alguns dos monitores daquela edição, percebemos que os laços afetivos estabelecidos foram bastante fortes, contribuindo inclusive para a volta deles à monitoria nos dois anos seguintes.

Se por um lado os laços afetivos estabelecidos podem contribuir para o projeto, deixando os monitores mais à vontade e servindo como mais um estímulo à sua 
permanência, por outro lado podem atrapalhar se a vontade de ficar junto superar o desejo de trabalhar pelo objetivo do projeto. Foi isso que se verificou na experiência de 2005, quando a preocupação com o projeto, construída durante a participação dos monitores em 2003, vira uma preocupação com o encontro que permitia a manutenção daquela boa relação proporcionada pela sua primeira participação na monitoria. Deixando de inovar e de se dedicar ao trabalho de ajuda aos colegas, aparece um ponto de inflexão na trajetória da monitoria.

Além disso, o desenrolar dos eventos do grupo de 2005 também nos indica a necessidade de estímulo interno quando se vivenciou uma experiência de sucesso no passado, para que ela não seja esvaziada, predominando a relação afetiva. Nesse caso, o processo de deslocamento da tarefa foi facilitado pelo professor, que não instigou os monitores a continuarem contribuindo para o projeto da maneira como eles vinham fazendo nos anos anteriores. O professor, como coordenador daquele grupo, não ofereceu o estímulo necessário e mais, acabou aderindo a uma situação em que se manterem juntos era mais importante que desenvolver o trabalho objetivo. Dessa forma, um pacto implícito foi criado entre os membros do grupo, impedindo que fosse revelada a sua pouca atuação perante os outros alunos. Tal fato fica mais evidente quando observamos o grupo de 2006, que não tendo uma relação afetiva fortemente construída permitiu que o porta-voz enunciasse a mensagem de insatisfação do grupo perante seu trabalho.

A maneira como cada grupo se relacionou com a tarefa proposta influenciou a trajetória do projeto ao longo de seus cinco anos de existência, mas tendo em vista que os grupos mudam, podemos analisar fatores mais gerais. Em algum momento ocorreu uma ruptura que deflagrou o início do declínio da monitoria e podemos tentar encontrála analisando aqueles elementos que foram constantes: o formato do projeto, o professor e a instituição.

Quando o projeto "mudou" do primeiro para o terceiro ano do ensino médio, ainda que tenha havido uma preocupação do professor com relação à adesão dos alunos à monitoria no novo contexto, nada foi feito para adaptar o seu formato à nova realidade.

O início do declínio da monitoria também parece coincidir com essa mudança de série. No primeiro ano do ensino médio há um clima de novidade pela saída do ensino fundamental e entrada em uma nova fase escolar, facilitando a inserção da monitoria como novidade, pois os alunos vivenciam mudanças em sua forma de estudar e se 
empenhar nas atividades escolares. Já no terceiro ano o clima é de fim dessa etapa e de vislumbre de ingresso no ensino superior. Os alunos, já cansados, não estão mais tão dispostos a atividades como a monitoria, preferindo o clima do “já acabou”. Parece-nos que o empenho dos alunos em um projeto inovador está diretamente relacionado aos interesses proporcionados por cada etapa de sua vida escolar, e que o professor deveria pensar em adaptações a cada uma delas. Um projeto que funciona muito bem no primeiro ano pode não ter a mesma receptividade no terceiro, por exemplo.

Com relação ao professor, fica evidente que, ao longo dos cinco anos de projeto, ele vai se envolvendo com outros desafios profissionais. Após o término de sua pósgraduação em 2004, ele se lança a novos desafios no ensino superior a partir de 2005 e passa a investir muito de seu tempo nessas atividades. Ao mesmo tempo em que ocorre esse crescente interesse por novos desafios, seu investimento na monitoria diminui.

Percebemos que os grupos são sensíveis a esse investimento do professor, pois eles acompanham a mudança de Emanuel, de forma que os últimos grupos formados não investem na monitoria como os primeiros. Se o professor esperava uma parceria com os monitores, eles por sua vez esperavam um coordenador, alguém que comandasse e propusesse novidades para seu trabalho, estabelecendo-se, assim, uma dependência mútua que paralisou o processo de ascensão a partir do momento em que o foco de Emanuel mudou e seu investimento na monitoria diminuiu. É importante que haja suporte a um projeto inovador ao longo de toda sua existência e estímulo ao avanço dos grupos de alunos envolvidos. Neste caso esse estímulo precisa vir do professor, em função da dependência que o projeto tinha dele, mas nem sempre é necessário que seja o professor a cumprir esse papel; poderia ser um coordenador, ou até mesmo algum ou alguns alunos.

Com relação à instituição, não houve grande participação desta no projeto e o seu não-envolvimento foi também determinante para os rumos da monitoria. A relação do professor com a instituição foi se tornando cada vez mais insustentável com o passar dos anos e a desilusão com a escola influenciou diretamente seu envolvimento com o projeto. Ao falar sobre a relação com a instituição, Emanuel reclama que a escola cede o espaço apenas, mas não se envolve com a proposta, pois seu objetivo era manter sua posição de "boa escola" e não necessariamente melhorar as propostas pedagógicas para atingir maior aprendizado dos alunos. A escola queria manter seu status, mas sem se incomodar com possíveis problemas surgidos por um projeto inovador, por isso cedia espaço, mas não dava suporte ao projeto e nem ao professor. 
Ao juntarmos todos esses fatores temos como hipótese que o ponto de inflexão, o momento da ruptura, acontece entre 2004 e 2005. Entre esses dois anos alguns fatores convergem: ocorre a mudança de série da monitoria, o professor termina sua dissertação e passa a se dedicar a outros projetos profissionais, as reclamações com relação à escola aumentam e um grupo de alunos que experimentou o sucesso anteriormente volta a compor a equipe de monitoria. Ainda, é preciso notar que apenas duas monitoras de 2004 voltaram à monitoria em 2006, indicando que aquela experiência já não havia sido tão intensa quanto as anteriores. Nossa hipótese é de que, com a conclusão da dissertação de Emanuel em 2004, a desilusão com a escola ganha cada vez mais peso e seu investimento no projeto diminui. O suporte nos parece essencial para a manutenção de uma proposta inovadora. Se por um lado o professor precisa dar suporte ao grupo de monitores, por outro é preciso que a instituição dê suporte a esse professor. Enquanto Emanuel estava fortemente envolvido com seu projeto de mestrado esse estímulo supria a falta da instituição; no entanto, quando a dissertação termina, o professor entra em um processo natural de experimentar novas oportunidades e, sem o apoio da instituição, não consegue mais sustentar os grupos de monitores.

Diante dessa situação, o projeto entra em processo de declínio em 2005 e o que ainda o mantém vivo é a relação que foi estabelecida entre os membros do grupo daquele ano. Em 2006, sem os laços afetivos tão fortes pautando as relações grupais, a insatisfação pela ineficiência no cumprimento da tarefa objetiva ganha voz, mas com a relação já bastante deteriorada do professor com a instituição, nenhuma intervenção é feita para mudar essa situação. Assim, o professor sai da escola e o projeto de monitoria morre.

\section{CONSIDERAÇÕES SOBRE O PROJETO}

É importante ressaltarmos aqui alguns pontos a respeito da monitoria. Um professor, realmente implicado em melhorar sua prática docente e em criar condições mais favoráveis para o aprendizado de seus alunos, criou um novo projeto para ser implantado em sua escola. Balizado por experiências vividas anteriormente, ele desenvolveu uma proposta para envolver alguns alunos do ensino médio em seu aprendizado de Física e utilizá-los como mediadores na disseminação do conhecimento aos outros alunos, colegas de classe. Mas sua intenção era ainda mais ampla, ele pretendia marcar aqueles que se dispusessem a viver a experiência da monitoria. Os 
monitores ajudam os colegas, mas recebem destes uma contrapartida que pode ser no âmbito da socialização ou de qualquer outra moeda de troca que se estabeleça implicitamente no processo. Essa atitude do professor de Física, ao conceber uma monitoria discente, é audaciosa e inovadora.

O projeto foi colocado em ação e muitos alunos tiveram a oportunidade de se tornarem monitores e participarem daquela experiência. É admirável que Emanuel tenha conseguido que tantos alunos tenham se disposto a participar de uma reunião que durava uma hora, depois da última aula de sexta-feira, para discutir como poderiam ajudar seus colegas! Não bastasse esse tempo dedicado, eles se organizavam para dar plantões, grupos de estudo, estavam à disposição dos colegas a qualquer momento (até mesmo no intervalo, se fossem procurados), corrigiam listas de exercícios para o professor, e para que tudo isso funcionasse, estudavam mais Física!

Ainda, não podemos ignorar a realidade na qual o grupo de monitoria está inserido. Estamos tratando de um grupo de adolescentes em uma escola cuja cultura discente é de não valorização do conhecimento, em que se quer apenas cumprir as tarefas burocraticamente para vencer essa etapa escolar de suas vidas o mais rapidamente possível. Dentro deste contexto, devemos levar em conta que esses jovens estão cheios de inseguranças e imaturidades inerentes a essa fase complicada do desenvolvimento, e vivem imersos em uma cultura estabelecida de não comprometimento com o conhecimento. Ainda assim, eles se dispuseram a compor um grupo, cujo objetivo era justamente o de contribuir para a disseminação do conhecimento físico entre seus colegas. Diante disso devemos nos perguntar o tamanho do ganho que isso representa.

Independente dos rumos que o projeto tomou, em todos os seus cinco anos de existência todos ganharam: monitores, professor e alunos.

Os monitores certamente aprenderam muito, em diversos âmbitos. Cada um foi marcado por sua participação no projeto de uma maneira, mas todos saíram com algum saber adquirido pela experiência vivida. O modelo de monitoria foi construído centrado na figura do monitor, que foi assumido como singularidade dentro de seu meio e trabalhado a partir desta concepção. Esses alunos assumiram as tarefas da monitoria e com isso passaram a dividir com o professor parte da responsabilidade dele, passaram a ser co-autores e protagonistas das experiências proporcionadas pelo projeto. Os monitores, mais do que quaisquer outros participantes da experiência, assumem diversas responsabilidades e certamente amadurecem ao ter que dar conta delas. 
Tais experiências passam pelo âmbito das relações estabelecidas e também do conteúdo disciplinar. Ao mesmo tempo em que a monitoria lhes proporciona mais contato com um número maior de pessoas, também exige deles uma maior preparação em termos de conteúdo para que possam dar conta de suas responsabilidades junto a esses colegas. Se um ganho importante é a socialização e o status adquirido perante os colegas, outro ganho inegável é com relação ao aprendizado de Física.

Também o professor se beneficiou da experiência em muitos sentidos. Além da satisfação pessoal de estar atuando em prol de uma mudança de atitudes no ambiente escolar, ele ganhou em termos de relação com os monitores e por criar mais possibilidades de caminhos para os alunos perseguirem o conhecimento físico. Além desses ganhos que já eram inicialmente pretendidos, com o desenrolar da monitoria o professor ainda se beneficiou de co-pensores para seu curso de Física. Os monitores acabavam se tornando mensageiros das questões de sala de aula, reportando problemas, elogiando atitudes que deram certo e contribuindo para pensar atividades que fizessem real sentido aos estudantes.

Com relação aos alunos, certamente ganharam mais uma oportunidade para se implicarem em seus estudos de Física. Se aproveitaram ou não, foi escolha de cada um, mas a oportunidade foi colocada e com diversos desdobramentos: plantões, atendimento individual, tutoria etc. E tudo isso sem eximir o professor de sua responsabilidade: o aluno poderia escolher entre procurar um monitor ou o professor, tendo portanto uma diversidade de possibilidades caso quisesse de fato resolver suas dificuldades com a disciplina.

Mesmo nos anos de declínio, mesmo que os monitores não estivessem verdadeiramente implicados com as tarefas da monitoria, ainda assim eles a realizaram (embora não tão criativamente quanto os pioneiros) e todos saíram ganhando. Em alguns anos ganharam mais, em outros ganharam menos, mas a monitoria não deixou de acontecer durante seus cinco anos de existência e contribuiu para alunos, monitores e professor. O projeto certamente tem seu mérito e merece destaque pelas oportunidades que proporcionou aos alunos daquela escola.

Além de todos esses ganhos devemos também ressaltar a importância sóciocultural dessa experiência, afinal viver em grupos é mais que uma necessidade. Educar para a maturação grupal, administrar conflitos e vivenciar as possibilidades e expectativas, frustrações e angústias de um grupo é educar para o convívio no bairro, na 
cidade, no país, despertando a co-responsabilidade para o futuro desejado, para o projeto de vida construído em comum, sempre em grupo.

\section{MAIS ALGUMAS CONSIDERAÇÕES}

De nossa vivência profissional sabemos que não é difícil encontrar projetos desenvolvidos com os alunos que se desenrolam de forma parecida com a monitoria analisada neste trabalho. É bastante comum que os projetos, propostos por um ou mais professores ou pela direção de uma escola, sejam, inicialmente, objeto de muito investimento. No entanto, com o passar do tempo, eles perdem seu brilho e aos poucos vão morrendo.

O professor é um elemento fundamental na implantação de um projeto. Em geral, é ele quem faz a proposta ou então é o intermediário entre a instância que propõe e os alunos que participarão. Ao nos perguntarmos qual é o papel do professor dentro de um projeto inovador encontramos para ele uma dupla função: professor e ao mesmo tempo coordenador. Como professor ele está sujeito a uma série de ansiedades, algumas próprias e outras que são depositadas nele. Ao se aventurar por uma nova proposta, o professor arrisca aquilo que já está consolidado, ao mesmo tempo em que cultiva a esperança de que a novidade traga avanços e benefícios em relação à situação atual. Já como coordenador, ele é responsável pelo grupo participante do projeto e tem a função de mantê-lo, promovendo a comunicação entre os membros e intervindo de forma eficiente para que ele alcance seu objetivo. Essa dupla função coloca o professor em uma posição central, pois ele é responsável pelo grupo que será coordenado, ao mesmo tempo em que é participante dele, pois sendo o projeto inovador, ele está sujeito às mesmas ansiedades que deve ajudar os outros integrantes a enfrentarem.

Neste sentido, vemos que o estabelecimento de um projeto freqüentemente está relacionado à constituição de um ou vários grupos (de professores, alunos ou ambos). Existe uma crença comum de que o trabalho em grupo é uma estratégia que seguramente trará melhores resultados, pois os participantes irão cooperar, debater idéias e somar suas contribuições em prol do objetivo comum. No entanto, isso nem sempre acontece. Quando se trabalha em grupo, uma série de fatores de ordem subjetiva pode influenciar fortemente o grupo em sua disposição para a tarefa. Portanto, conhecer teorias de grupo se torna fundamental para a identificação desses fatores e para o planejamento de ações que contribuam para uma mobilização dos membros do grupo 
em direção à cooperação. No entanto, muitas vezes o coordenador (que freqüentemente é o professor) trabalha baseado em suas próprias experiências pessoais e concepções prévias sobre o trabalho grupal.

Neste ponto, podemos vislumbrar a importância de se discutir fundamentos teóricos e técnicos a respeito da influência de fatores subjetivos no trabalho grupal durante os cursos de formação de professores. Infelizmente, a ênfase dada a esse assunto durante a formação inicial é mínima ou até inexistente, perdendo-se aí um importante conhecimento para que o professor lide com situações coletivas.

As diversas relações que podem se estabelecer entre os elementos que fazem parte de um projeto inovador (professor-alunos; professor-instituição; projeto-contexto) e seu interjogo, são determinantes para a proposição, sobrevivência e manutenção desse projeto.

Primeiramente podemos destacar a importância da adequação do projeto ao contexto no qual será inserido. Cada série escolar possui sua especificidade, e um projeto bem sucedido em uma delas pode não ter o mesmo êxito em outra. É importante que o professor esteja atento e aberto a fazer adaptações que contemplem as características específicas e as necessidades de cada etapa escolar.

O estabelecimento de laços afetivos também merece atenção. Ao mesmo tempo em que pode facilitar o envolvimento com a tarefa proposta por criar um clima favorável, pode acabar atrapalhando seu desenvolvimento quando a manutenção desses laços passa a ser mais importante que o sucesso do projeto. É preciso atenção para que esses laços sejam aproveitados como facilitadores do trabalho, servindo de estímulo à manutenção do projeto, mas sem esvaziá-lo de seu objetivo educacional. Mais uma vez aqui entra em ação o professor, a quem cabe o cuidado com essas questões e que, munido de conhecimentos a respeito da dinâmica que se estabelece, pode evitar entrar no "jogo" das relações afetivas e usá-las a favor do trabalho a ser desenvolvido.

Finalmente, os diferentes suportes necessários ao projeto são fundamentais para determinar os caminhos trilhados. Que no início da implantação de um projeto inovador o suporte é essencial, podemos pensar que seja uma conclusão bastante óbvia. Mas como fica essa questão ao longo de várias edições de um mesmo projeto? Que tipos de suporte são necessários e por quanto tempo? O projeto pode "ganhar asas" e se autosustentar? Ele pode sobreviver independentemente do seu criador? 
Os resultados que obtivemos mostraram que o suporte do professor a um projeto inovador ao longo de suas várias edições é fundamental para que ele se mantenha sempre em processo de ascensão. No entanto, ao sustentar o projeto, o professor precisa, ele mesmo, de algum suporte. Esse suporte deve ser fornecido pela instituição.

A relação instituição-professor se torna também fundamental para a sobrevivência de um projeto inovador. É necessário um acoplamento entre essas duas instâncias para que os alunos participantes obtenham o suporte necessário para se manterem focados. A institucionalização de um projeto parece ser o caminho para sua sobrevivência independente do professor. Se a instituição de fato compra a idéia, contribui para sua disseminação dentro do micro-cosmo daquela escola, consolidando uma boa proposta de trabalho que, partilhada por mais professores, pode receber cada vez mais contribuições e entrar em um processo de constante reinvenção, inovando e progredindo.

Sem dúvida promover e sustentar uma inovação dentro do ambiente escolar é um grande desafio, pois envolve diversos fatores, de diferentes naturezas que podem acabar convergindo para um resultado bastante diferente daquele pretendido. Fica claro que o acoplamento instituição-professor-alunos é essencial ao se tratar de uma inovação. Sem o suporte institucional o professor se vê limitado e, sozinho, não consegue sustentar os alunos engajados no projeto proposto.

Para concluir nossas considerações finais achamos importante levantar algumas questões referentes ao processo de promover e sustentar inovações. O caso analisado aponta para a complexidade das relações que se estabelecem ao longo do tempo entre os vários atores institucionais. Que condições mínimas é preciso garantir para que as inovações tenham chances de se estabilizar? Quando uma mudança curricular atinge certa estabilidade, que tipo de desafios enfrenta o grupo que a promoveu? Que novas dinâmicas podem se estabelecer?

Parece-nos que o tema da implantação e sustentação das mudanças curriculares seja fundamental para que os resultados das pesquisas em Educação em Ciências possam efetivamente influenciar as salas de aula. Desde que a área de pesquisa se tornou uma instituição no Brasil e as pesquisas adquiriram um caráter sistemático muitas tentativas de inovação curricular foram realizadas. É nossa opinião que deveria ser feito um esforço para analisá-las e divulgá-las, para que seus resultados possam colaborar tanto para o avanço teórico da área quanto para a melhoria efetiva do Ensino de Ciências. 


\section{REFERÊNCIAS BIBLIOGRÁFICAS}

ANZIEU, D.; MARTIN, J-Y. La dinámica de los grupos pequeños. Buenos Aires: Kapeluz, 1971.

ANZIEU, D. O Grupo e o Inconsciente: o imaginário grupal. São Paulo: Casa do Psicólogo, 1993.

BAROLLI, E. Reflexões sobre o trabalho dos estudantes no laboratório didático. Tese de Doutorado. São Paulo, Faculdade de Educação da Universidade de São Paulo, 1998.

BAROLLI, E.; VILLANI, A. Laboratório Didático e Subjetividade. Investigações em Ensino de Ciências, v. 3, n. 3, 1998.

BARROS, J. C.; REMOLD, J.; SILVA, G. S. F.; TAGLIATI, J. R. Engajamento interativo no curso de Física I da UFJF. Revista Brasileira de Ensino de Física, v. 26, n. 1, p. 63-69, 2004.

BARROS, M. A.; VILLANI, A. A dinâmica de grupos de aprendizagem de física no ensino médio: um enfoque psicanalítico. Investigações em Ensino de Ciências, v. 9, n. 2, p. 115-136, 2004.

BARROS, M. A.; LABURÚ, C. E.; ROCHA, Z. F. D. C. Análise do vínculo entre grupo e professora numa aula de ciências do ensino fundamental. Ciência \& Educação, v. 13, n. 2, p. 235-251, 2007.

BION, W. R. Experiências com Grupos: os fundamentos da psicoterapia de grupo. $2^{\mathrm{a}}$ edição. Rio de Janeiro: Imago, 1975.

BLEGER, J. Temas de Psicologia: entrevista e grupos. $2^{\text {a }}$ edição. São Paulo: Martins Fontes, 2003.

Brasil. Ministério da Educação. Parâmetros Curriculares Nacionais. Brasília: MEC/SEF, 1997.

BROWN, J. S.; COLLINS, A.; DUGUID, P. Situated cognition and the culture of learning. Educational Researcher, v. 1, n. 1, p. 32-42, 1989.

CIAMPONE, M. H. T. Grupo Operativo: construindo as bases para o ensino e a prática da enfermagem. Tese de Livre Docência. São Paulo, Universidade de São Paulo, 1998.

COLL, C. Los contenidos en la reforma. Madrid: Santillana, 1992.

DUSCHL, R. Más allá del conocimiento: los desafios epistemológicos y sociales de la enseñanza mediante el cambio conceptual. Enseñanza de las Ciencias, v. 13, n. 1, 1995.

FERNANDES, W. J et al. Grupos e Configurações Vinculares. Porto Alegre: Artes Médicas, 2003.

FERNÁNDEZ, A. M. O campo grupal: notas para uma genealogia. São Paulo: Martins Fontes, 2006.

GREF: Grupo de Reelaboração do Ensino de Física. Física I: Mecânica / GREF. $5^{\mathrm{a}}$ edição. São Paulo: Editora Universidade de São Paulo, 1999. 
GUIMARÃES, L. F., SILVA, G .S. F, VILLANI, A. Grupos de Aprendizagem: O papel da intervenção do professor. V Encontro de Nacional de Pesquisa em Educação em Ciências. ABRAPEC, Bauru, 2005.

GUIMARÃES, L. F.; VILLANI, A. As Suposições Básicas em um Grupo de Monitoria Discente de Física. Atas do X EPEF, 2006.

JULIO, J.; VAZ, A. O professor de Física como "co-pensor" de grupos operativos de alunos do Ensino Médio. V Encontro Nacional de Pesquisa em Educação em Ciências. ABRAPEC, Bauru, 2005.

KAËS, R. O Grupo e o Sujeito do Grupo: elementos para uma teoria psicanalítica do grupo. São Paulo: Casa do Psicólogo, 1997.

Os espaços psíquicos comuns e partilhados: transmissão e negatividade. São Paulo: Casa do Psicólogo, 2005.

KAËS, R. et al. Realidade Psíquica e Sofrimento nas Instituições. São Paulo: Casa do Psicólogo, 1991.

KIRSCHNER, P. A. Epistemology, practical work and academic skills in science education. Science \& Education, v. 1, p. 273-299, 1992.

KUPFER, M. C. Freud e a educação: o mestre do impossível. São Paulo: Scipione, 1989.

LAPLANCE, I.; PONTALIS, J-B. Vocabulário de Psicanálise. São Paulo: Martins Fontes, 1988.

LÜDKE, M.; ANDRÉ, M. E. D. A. Pesquisa em Educação: abordagens qualitativas. Col. Temas básicos da educação e ensino. São Paulo: EPU, 1986.

MOREIRA, M. A. Pesquisa em Ensino: o vê epistemológico de Gowin. Temas Básicos de Educação e Ensino. São Paulo: EPU, 1990.

OLIVEIRA, E. R. Monitoria Discente no Ensino Médio de Física: promovendo singularidades. Dissertação de Mestrado. São Paulo, Instituto de Física da Universidade de São Paulo, 2004.

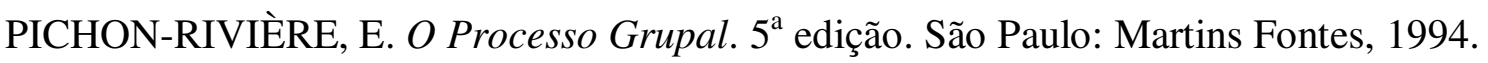
Teoria do Vínculo. $5^{\text {a }}$ edição. São Paulo: Martins Fontes, 1995.

SANCHEZ, R. U. Grupos Operativos de Aprendizagem: uma perspectiva de mudança para a relação ensino aprendizagem. Dissertação de Mestrado. São Paulo, Instituto de Física, Universidade de São Paulo, 2002.

SILVA, C. A. Teorias de Grupo em Pauta: contribuições ao campo educacional. Dissertação de Mestrado. São Paulo, Faculdade de Educação da Universidade de São Paulo, 2000.

SILVA, G. S. F. As intervenções do professor e o processo grupal nas aulas de Física: uma análise à luz da teoria de Grupos Operativos. Dissertação de Mestrado. São Paulo, IFUSP, 2008

SILVA, G. S. F.; VILLANI, A. A construção de intersubjetividade nas aulas de Física: como e por que um grupo funciona? Anais do Encontro de Pesquisadores em Ensino de Física, CD-ROM v. 10, Londrina, 2006. 
WEIGERT, C.; VILLANI, A.; FREITAS, D. A Interdisciplinaridade e o Trabalho Coletivo : análise de um planejamento interdisciplinar. Ciência \&Educação, v. 11, n. 1, p. 145-164, 2005.

WHEATLEY, G. H. Constructivist perspectives on science and mathematics learning. Science Education, v. 75, n. 1, 1991.

VALADARES, J. M. As Formas e a Construção da Subjetividade em um Grupo de Professores. Dissertação de Mestrado. São Paulo, Instituto de Física da Universidade de São Paulo, 2002.

VALADARES , J. M.; \& VILLANI, A. Continuidade e ruptura no trabalho coletivo de professores. Atas do VIII EPEF. São Paulo: Águas de Lindóia, 2002.

Um referencial psicanalítico para os grupos de aprendizagem em ciências. Livro de Resumos IV ENPEC. Bauru: ABRAPEC, 2003.

VILLANI, A.; et al. Contribuições da Psicanálise para uma Metodologia de Pesquisa em Educação em Ciências. In: SANTOS, F. M. T; GRECA, I. M. (orgs.). A Pesquisa em Ensino de Ciências no Brasil e suas Metodologias. Ijuí: Unijuí, 2006.

ZIMERMAN, D. Fundamentos Básicos das Grupoterapias. Porto Alegre: Artes Médicas, 1993. 